\title{
Neogene - Quaternary slow coastal uplift of Western Europe through the perspective of sequences of strandlines from the Cotentin Peninsula (Normandy, France)
}

K. Pedoja ${ }^{1,2,3}$, J. Jara-Muñoz ${ }^{4}$, G. De Gelder ${ }^{5}$, J. Robertson ${ }^{6}$, M. Meschis ${ }^{6}$, D.

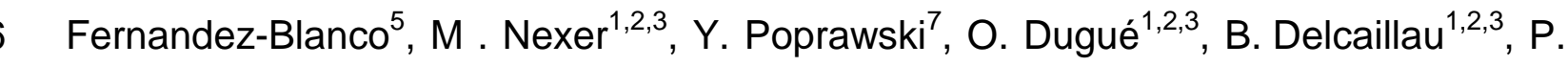

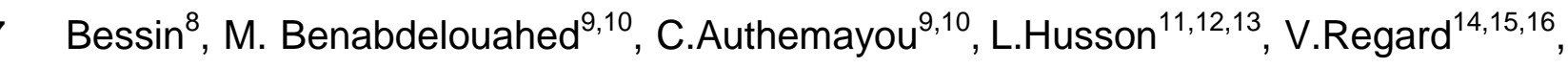
D. Menier ${ }^{9,10}$, B. Pinel $1^{1,2,3}$

${ }^{1}$ Normandie Univ, France ; ${ }^{2}$ UCBN, M2C, F-14000 Caen, France; ${ }^{3}$ CNRS, UMR 6143 M2C, F-14000 Caen, France kevin.pedoja@unicaen.fr. ${ }^{4}$ Institut für Erd- und Umweltwissenschaften, University Potsdam, 14476 Potsdam, Germany. ${ }^{5}$ Institut de Physique du Globe de Paris, Sorbonne Paris Cité, Univ Paris Diderot, UMR 7154 CNRS, F-75005 Paris, France. ${ }^{6}$ Department of Earth and Planetary 4 Sciences, Birkbeck, University of London, WC1E 7HX, UK. ${ }^{7}$ Institute of Earth Sciences Jaume Almera, ICTJA-CSIC, Group of Dynamics of the Lithosphere, Spain. ${ }^{8} \mathrm{LPG}$ - Le Mans, UMR 6112, Université 6 du Maine, Avenue Olivier Messiaen, 72085 Le Mans, France. ${ }^{9}$ Laboratoire Domaines océaniques, 7 UMR 6538- IUEM, Université de Brest, CNRS, Plouzané, France. ${ }^{10}$ Université de Bretagne Sud, 8 GMGL IUEM CNRS 6538 Domaines Océaniques. ${ }^{11}$ Univ. Grenoble Alpes, ISTerre, F-38014 Grenoble, France ${ }^{12} \mathrm{CNRS}$, ISTerre, F-38014 Grenoble, France ${ }^{13}$ IRD, ISTerre, F-38014 Grenoble, France. ${ }^{14}$ Université de Toulouse ; UPS (OMP) ; GET ; 14 Av Edouard Belin, F-31400 Toulouse, France ${ }^{15}$ 1 CNRS ; GET ; F-31400 Toulouse, France. ${ }^{16}$ IRD; GET ; F-31400 Toulouse, France. 
Morpho-stratigraphy of low-lying terraces from $\mathrm{N}$ Cotentin

Description of the polygenic coastal erosion surfaces (rasas) of Cotentin

Late Cenozoic paleogeographic evolution

Database on Neogene and Quaternary shorelines of Western Europe

Wholesale analysis of the Late Cenozoic uplift of Western European coastlines 
23 Keywords : marine terrace; rasa; Cotentin and western Europe; Neogene and

24 Quaternary coastal uplift

\section{Abstract}

The Cotentin Peninsula (Normandy, France) displays sequences of marine terraces and rasas, the latter being wide Late Cenozoic coastal erosion surfaces, that are typical of Western European coasts in Portugal, Spain, France and southern

31 England. Remote sensing imagery and field mapping enabled reappraisal of the

32 Cotentin coastal sequences. From bottom to top, the $\mathrm{N}$ Cotentin sequence includes

33 four previously recognized Pleistocene marine terraces ( $\mathrm{T} 1$ to $\mathrm{T} 4$ ) at elevations $<40$

$34 \mathrm{~m}$ as well as four higher and older rasas (R1 to R4) reaching $200 \pm 5 \mathrm{~m}$ in elevation.

35 Low-standing marine terraces are not observed in the central part of the Peninsula 36 and a limited number of terraces are described to the south. The high-standing rasas

37 are widespread all over the peninsula. Such strandline distributions reveal major 38 changes during the Late Cenozoic. Progressive uplift of an irregular sea-floor led to 39 subaerial exposure of bathymetric highs that were carved into rocky platforms, rasas 40 and marine terraces. Eventually, five main islands coalesced and connected to the

41 mainland to the south to form the Cotentin Peninsula. On the basis of previous dating 42 of the last interglacial maximum terrace (i.e. Marine Isotopic Stage, MIS 5e), 43 sequential morphostratigraphy and modelling, we have reappraised uplift rates and 
44 derived: (i) mean Upper Pleistocene (i.e. since MIS 5e $~ 122+/-6$ ka, i.e. kilo annum)

45 apparent uplift rates of $0.04 \pm 0.01 \mathrm{~mm} / \mathrm{yr}$, (ii) mean Middle Pleistocene eustasycorrected uplift rates of $0.09 \pm 0.03 \mathrm{~mm} / \mathrm{yr}$, and (iii) low mean Pleistocene uplift rates

47 of $0.01 \mathrm{~mm} / \mathrm{yr}$. Extrapolations of these slow rates combined with geological evidence 48 implies that the formation of the sequences from the Cotentin Peninsula occurred 49 between $3 \mathrm{Ma}$ (Pliocene) and $15 \mathrm{Ma}$ (Miocene), which cannot be narrowed down 50 further without additional research. Along the coasts of Western Europe, sequences 51 of marine terraces and rasas are widespread (169 preserve the MIS 5e benchmark). 52 In Spain, Portugal, S England and other parts of western France, the sequences 53 morphostratigraphy is very similar to that of Cotentin. The onset of such Western 54 European sequences occurred during the Miocene (e.g. Spain) or Pliocene (e.g. 55 Portugal). We interpret this Neogene - Quaternary coastal uplift as a symptom of the increasing lithospheric compression that accompanies Cenozoic orogenies.

60 Emerged sequences of fossil coastal landforms (marine terraces and rasas which are

61 wide Late Cenozoic polygenic coastal platforms) with associated deposits ("raised 62 beaches") are present along the shores of Western Europe, in Portugal, Spain, 63 France, UK and Ireland (Pedoja et al., 2011; 2014). In France and in the British Isles, 64 earlier studies (e.g., Prestwich, 1862-1863, 1892; Home, 1912; Coutard et al., 2006) - 
65 with notable exceptions (e.g., Guilcher 1974; Lautridou, 1989) - ignored the higher

66 and older landforms (i.e. the rasas) within the coastal sequences, while in Iberia, 67 rasas were long interpreted as geomorphic indicators of former sea levels (e.g., 68 Breuil et al., 1942; Teixeira, 1944).

70 Herein, we reappraise the coastal sequences of the Cotentin Peninsula (Normandy, 71 France) because this area exhibits some of the northernmost long-lasting (i.e. 72 including rasa) coastal sequences along the Atlantic passive margin where 73 Pleistocene coastal deformation is generally homogeneous over long distances 74 (Pedoja et al., 2014). We mapped the Neogene and Quaternary strandlines from 75 Cotentin and measured their elevations through field studies, satellite images 76 (Landsat, SPOT) and Digital Elevation models DEM (MNT Litto 3D provided by IGN, 77 Institut de Géographie National). Age controls come from previous studies at the 78 same sites (e.g., Antoine et al., 1998; Cliquet et al., 2003; 2009; Coutard, 2003; 79 Coutard et al., 2005, 2006, Clet-Pellerin et al., 1997; van Vliet-Lanoë et al., 2002; 80 Dugué, 2003). We derived and extrapolated different Pleistocene uplift rates and 81 undertook modelling to propose plausible age ranges for the undated strandlines of 82 the sequence. The inferred timing is then discussed within the broader framework of 83 regional geology. The Late Cenozoic paleogeographical evolution of Cotentin has 84 already been interpreted as that of an island that connected to the mainland (see van 85 Vliet-Lanoë et al., 2000; 2002). We present geomorphic evidence - the pattern of 86 fossil shorelines associated with the rasas - which support this evolution. 
88 In order to reframe the uplift of the Cotentin Peninsula and to evidence coastal uplift

89 at a continental scale, we compiled a regional synthesis of Late Cenozoic sea-level 90 changes for Atlantic Europe (Portugal, Spain, France, and the British Isles). The 91 coastal sequences of Western Europe have been somehow neglected in the most 92 recent global approaches (e.g. Murray-Wallace and Woodroffe, 2014; Pedoja et al., 93 2014) and not interpreted as a continuous, 2000 -km-long uplifted coastal segment.

94

95

\section{Settings}

96

97

\subsection{Geodynamics and geology}

98

99 Since the upper Cretaceous, the convergence between the African and the European 100 plates affected the Western European passive margin. During the Pyrenees and the 101 Alpine orogenies, the main compressive stages reactivated structures of the passive 102 margin from upper Cretaceous to lower Miocene (e.g., Dèzes et al., 2004) with high 103 convergence rates, $(\sim 20 \mathrm{~mm} / \mathrm{yr}$ ) during the upper Cretaceous (Rosenbaum et al., 104 2002). From the Late Miocene to the Quaternary, the convergence is characterized 105 by low rates with a modern rate ranging from 2 to $5 \mathrm{~mm} / \mathrm{yr}$ (Dèzes et al., 2004). In the 
106 foreland, convergence coincided with oblique extensional processes such as the 107 opening of the European Cenozoic rifts (Dèzes et al., 2004).

109 The Cotentin Peninsula on the North Atlantic margin, forms a promontory into the 110 English Channel (Fig. 1). The Peninsula belongs to the Armorican Massif and bounds 111 the Paris Basin (Juignet, 1980). Its basement, into which the marine terraces and 112 rasas are carved, is made of sedimentary and igneous rocks (Dupret et al., 1990; 113 Ziegler and Dèzes, 2007; Ballèvre et al., 2009). Cadomian and Variscan faults delimit $114 \mathrm{~N} 70^{\circ}$ and $\mathrm{N} 120^{\circ}$ grabens on the peninsula (Gresselin, 2000; Butaeye, 2001; 115 Lagarde et al. 2000; 2003). During the second half of the Mesozoic, the Peninsula 116 emerged and continental erosion/subtropical alteration induced the planation of the 117 Variscan topography (Klein, 1975), although Cenomanian marine incursions are 118 known (Dugué et al., 2007; 2009; Bessin, 2015). During the Cenozoic, compressive 119 events alternated with relaxation phases (van Vliet-Lanoë et al., 2002); the Peninsula 120 was exposed to alternating marine sedimentation (coming from the west) and 121 continentalisation (Guilcher, 1949; Klein, 1975; Baize, 1998; Bonnet et al., 2000; van 122 Vliet-Lanoë et al., 2002; Guillocheau et al., 2003; Dugué et al., 2007, 2009; Bessin et 123 al., 2015). On the NW Armorican massif, Paleogene long wavelength/low amplitude 124 deformation (Dugué, 2003; Dugué et al. 2007, 2009) resulted in uplift, emergence, 125 and subtropical subaerial weathering of the area which led to the formation of a 126 planation surface (Baize, 1998; Ziegler, and Dèzes, 2007). During the late Middle 127 Eocene, the North Atlantic waters reoccupied the area (Dugué, 2003; Dugué et al., 
128 2007, 2009; Bauer et al., 2016). Upper Eocene and Lower Oligocene deformations of 129 the area (Bonnet et al., 2000; Guillocheau et al., 2003; Dugué, 2003; Dugué et al., 1302007 ; 2009) induced a resurfacing of the main planation surface to a lower one. 131 North Cotentin emerged during the Upper Paleocene (Dugué et al., 2009), whereas 132 in the Seuil du Cotentin basin (Fig. 1C), marine incursions occurred during the

133 Oligocene and Middle Miocene times (Langhian - Serravallian, open marine facies; 134 Baize, 1998; van Vliet-Lanoë et al., 2002; Dugué et al., 2009). As the closure of the 135 seaway once constituted by the Seuil du Cotentin area is an important benchmark for 136 the regional coastal evolution, its Plio-Quaternary sedimentary record is presented 137 and discussed section 4.4.3.

\subsection{Geomorphology}

141 The English Channel bordering the Cotentin Peninsula is an epi-continental sea; its

142 floor, presently at $<60 \mathrm{~m}$, emerged periodically over glacial cycle timescales. During 143 low-stands, the sea bottom was dissected by a fluvial network that constitutes, at 144 present, the offshore extension of modern rivers (the Seine, the Somme and the 145 Solent) (Graindor, 1964; Larsonneur et al., 1975; Auffret et al., 1980; Gibbard, 1988; 146 Hamblin et al., 1992; Bridgland, 2002; Antoine et al., 2003; Lericolais et al., 2003; 147 Mellett et al., 2013; Tessier et al., 2013). These rivers acted as tributaries that 
148 merged during glacial low-stands into a larger river positioned off the present coast of

149 Cotentin (Larsonneur et al., 1975; Benabdellouahed, 2013).

150

151 The coasts of Cotentin are characterized by sea-cliffs with elevations of $\sim 100 \mathrm{~m}$ at

152 Nez de Jobourg and less than $\sim 4 \mathrm{~m}$ near Dielette (Fig. 1C). The cliffs alternate with

153 sedimentary embayments underlined by pebble or shingle beaches and/or beach-

154 ridges lying on sand (e.g. Ecalgrain embayment). At many sites, Quaternary

155 continental deposits such as Holocene dunes or Pleistocene loess and periglacial

156 deposits, known as heads, are overlying the terraces (i.e. Biville and Hatainville area,

157 West Cotentin, North of Barneville-Carteret) (Lautridou et al., 1999).

158

159 The raised beaches and marine terraces from Cotentin have been extensively 160 studied over 120 years (e.g., Bigot, 1897, 1898, 1930, 1931; Elhaï, 1960; Graindor, 161 1964; Pareyn, 1980; Scuvée and Alduc, 1981; Lautridou, 1983, 1985, 1989; 162 Lautridou et al., 1999; Coutard, 2003; Coutard et al., 2005, 2006; Cliquet et al., 2009; 163 Cliquet, 2015; Nexer, 2015). To the NE of the Peninsula (Fig. 1C), Coutard et al., 164 (2006) described four terraces culminating at $\sim 40 \mathrm{~m}$; T1 has its shoreline angle (i.e. 165 the intersection between the rocky platform and the fossil sea cliff of a marine 166 terrace) at $6 \pm 1 \mathrm{~m} \mathrm{NGF}$ (the Principal Datum for France, Nivellement général de la 167 France, see definition NGF section 3), T2's shoreline angle was measured at $17 \pm 2$ $168 \mathrm{~m}$ NGF. The shoreline of T3 is present at $26 \pm 2 \mathrm{~m}$, and that of T4 at $31 \pm 2 \mathrm{~m}$, locally 
at $38 \pm 1 \mathrm{~m}$ (Coutard et al., 2005, 2006). Based on five luminescence (OSL) datings

170 on T1 coastal deposits sampled at the inner edge of the T1 terrace, Coutard et al. 171 (2006) proposed to allocate T1 to T4 to the last four interglacials (MIS 5e, 7, 9, and

172 11). A submerged terrace, observed on bathymetrical charts at $-20 \mathrm{~m} \mathrm{NGF}$ at La 173 Mondrée site (LM on Fig. 1C) was interpreted as the geomorphic record of a sea174 level stand during Marine Isotopic Stage (MIS) 5c or 5a (Coutard et al. 2006). Later 175 studies focused on archaeology and environmental settings (e.g. Cliquet \& Lautridou, 176 2009) using luminescence dating of the Middle Palaeolithic settlements at Gélétan, 177 Anse du Brick, Port-Racine, Ecalgrain bay, and Le Rozel sites (Cliquet et al., 2003, 178 2009; Cliquet, 2015). MIS 7 deposits were described on T2 at Rocher Gélétan and 179 on T1 on the North Ecalgrain Bay. The dating performed at Rocher Géletan was 180 carried out on reworked burnt flint (silex chauffé en position secondaire, Cliquet et al., 181 2003) and impedes a confident correlation with MIS 7. At the Ecalgrain site, MIS 7 182 deposits have been described below those related to MIS 5e (Lautridou, 1983). A 183 more recent study, including dating, proposed a reworking by periglacial processes of 184 the MIS 7 coastal deposits on the MIS 5e platform (Cliquet et al., 2009).

186 Less attention has been paid to the coastal sequences of S Cotentin (Fig. 1B). To the 187 SW, at sites Hacqueville and Hauteville-Annoville (sites 9 and 10 on Fig. 1B), the MIS 188 5e benchmark defines a strandline conforming to the modern one (Lautridou 1983, 189 1985, 1989; Lautridou et al., 1999). To the SE of the Seuil du Cotentin, a sequence 190 of marine terraces is described at Grandcamp Maisy (site 19 on Fig. 1B; Lautridou, 
191 1989; Coutard et al., 1979; Coutard and Lautridou, 1975), Asnelle Meuvaine (site 20

192 Fig. 1B; Bates et al., 2003; Pellerin et al., 1987) and Graye (site 21 Fig. 1B; Pellerin 193 and Dupeuble, 1979).

194

195 Concerning the upper part of the sequence, marine deposits on the La Pernelle 196 platform (NE Cotentin) were described at 90-110 m (Pareyn, 1980) but the outcrops 197 were not further observed (Baize, 1998). The sediments described (Pareyn, 1980) 198 are undated, azoic, supposedly marine deposits present at La Pernelle but also on 199 the rasa south of Cherbourg (Hameau du Cloquant, La Glacerie, on La Boissais fossil 200 island, see below) (Vérague, 1983). For the latter site, Vérague (1983) did a 201 granulometric and chemical comparison with deposits from another outcrop in the 202 area, and proposed a pre-Pliocene age for those deposits. Vérague (1983) noted 203 that: i) their morphometric parameters are different from those of Cenomanian and 204 Quaternary deposits, and, ii) their high kaolinite-content and depletion in silica 205 suggests weathering under subtropical climates. In NE Cotentin, Coutard et al. 206 (2006) described the lower part of the coastal sequence as overlooked by several 207 high "continental plateaux" ranging from 90 to $150 \mathrm{~m}$ (Coutard et al., 2006). Bessin et 208 al. (2015) also interpreted the upper surfaces of $\mathrm{N}$ Cotentin as continental in origin. In 209 S Cotentin, Lautridou (1989) described Pliocene and Miocene coastal deposits 210 ("Walton Crag") within the same area, to the NE of Hauteville-Annoville (site 10 Fig. 211 1B). Lautridou (1989) highlighted the relationship between the deposits and planation 212 surfaces (that he named plateaux). Describing two planation surfaces (called rasas in 
213 this study) with Miocene and Pliocene deposits, he concluded that the platforms were

214 not separated by faults which could be explained by their marine origin. Finally, 120

$215 \mathrm{~km}$ southward of N Cotentin, in the Mayenne area (site Champéon and Saint-Denis216 de-Gastines in Table 3 supplementary data), some outcrops are interpreted as

217 Pliocene coastal deposits (which reworked older Cenomanian to Eocene deposits) 218 overlying marine planation surfaces (i.e. rasas) (Gautier, 1967; Fleury et al., 1989).

219 We emphasize that the rasas possibly reshaped antecedent continental planation 220 surfaces, as some of them are overlain by scattered marine sedimentary remnants 221 (see Bessin et al., 2015 for a review).

\section{Background and methods}

224

225

\subsection{Late Cenozoic coastal staircase sequences and sea level}

226

227 Late Cenozoic staircase sequences of coastal indicators develop concomitantly with 228 sea-level changes on uplifting coastlines (Lajoie, 1986; Murray-Wallace and 229 Woodroffe, 2014). The elevation of the shoreline angle (i.e. intersection between the 230 rocky platform and the fossil sea cliff) of a marine terrace or a rasa (see below for 231 definitions) provides a good approximation to the location and elevation of a former 232 shoreline and, hence, a marker for relative sea level (Lajoie, 1986). The sequence 
233 corresponds to the geomorphic record of the Late Cenozoic high-stands (interglacial

234 and interstadial) superimposed on an uplifting coast (Lajoie, 1986). At a global scale 235 the formation of coastal sequences was likely operative since minima in the middle 236 Miocene and locally (regionally) since the Eocene. The staircase shaping of coasts 237 increased during the Pliocene and Pleistocene as a consequence of the 238 intensification of eustatic sea-level oscillations (Pedoja et al., 2014), as inferred from 239 the isotopic record (Lisiecki and Raymo, 2005).

\subsection{Description of landforms}

243 As rocky shore platforms, their modern counterpart, marine terraces are flat coastal

244 surfaces bounded by steeper slopes, the inner slopes corresponding to a fossil sea 245 cliff (Bradley, 1957; Bradley and Griggs, 1976; Lajoie, 1986). Marine terraces form as 246 a result of coastal erosion ("wave-cut" terraces, i.e. a fossil rocky shore platform as in 247 Bradley, 1957) combined with accumulation of shallow marine deposits (Murray 248 Wallace and Woodroffe, 2014). Depending on the thickness of the coastal deposits 249 on the fossil shore platform (more or less than 1-2 $\mathrm{m}$ ) there is a distinction between a 250 marine terrace and a wave-built terrace (Jara-Muñoz \& Melnick, 2015). "Raised 251 beaches" is old terminology (Dunlop, 1893) that corresponds to the coastal deposits 252 associated with a marine terrace found emerged within the sea cliff and generally 253 overlain by continental deposits. The shoreline angle of a terrace (or a rasa - see 
254 below) corresponds to the intersection between the fossil coastal platform and the 255 fossil sea cliff. Its elevation is used in any quantification of tectonics or eustatic sea 256 level (Lajoie, 1986).

258 Rasas are wide, elevated coastal planation surfaces corresponding to sequences of 259 terraces wherein the shoreline angles are not observed. (see Fig. 2 in Pedoja et al. 260 2014). The word "rasa", first used to describe such rocky surfaces on the northern 261 coasts of Spain (Cueto and Rui Diaz, 1930; Hernandez-Pacheco 1950 both in 262 Guilcher, 1974), was extended to landforms present in Morocco (e.g. Oliva, 1977), 263 Tunisia (Paskoff and Sanlaville, 1983), Algeria (Authemayou et al., 2017), Lebanon 264 (Sanlaville, 1974), Chile (e.g. Regard et al., 2010; Melnick, 2016), Peru and Ecuador 265 (where rasa are locally named Tablazo e.g. Sheppard, 1927; 1930; Pedoja et al. 266 2006a, b), Costa Rica (Battistini and Bergoeing, 1982), eastern Canada (Allard and 267 Tramblay, 1981) and Scotland (Dawson et al., 2013). Rasas are: 1) of polygenic 268 origin - marine erosion occurred during various stands in sea level suggesting that re269 occupation processes occurred on the rocky platform (Pedoja et al. 2006a,b; 2011; 270 2014; Regard et al. 2010; Dawson et al., 2013; Melnick, 2016; Authemayou et al., 271 2017); and 2) old features, as evidenced through direct dating; i.e. $>0.5 \mathrm{Ma}$ (e.g., 272 Alvarez-Maron et al., 2008; Quezada et al., 2007) and most generally associated to 273 areas experiencing low uplift $(<0.2 \mathrm{~mm} / \mathrm{yr}$; Pedoja et al. 2011, 2014; Melnick, 2016; ; 274 Authemayou et al., 2017). In short, on slowly uplifting coasts, the formation of rasas 275 was promoted before and during early Pleistocene times, during periods of faster 
276 oscillations and lower amplitudes in sea-level fluctuations than since the Middle

277 Pleistocene.

279 Fig. 2 sketches a 3D idealized view of a coastal sequence similar to that of Cotentin 280 which extends above sea level (rasa 1 to 4 , Terrace T1 to 4), at sea level (T0 the 281 modern shore platform) and below sea level ( $\mathrm{T}-1)$. The terraces and rasas are 282 defined as sub-planar, shallowly seaward-dipping surfaces between sea cliffs. T3 is 283 a compound terrace; it locally includes a low fossil sea cliff $(<2 \mathrm{~m})$ separating two 284 terraces (T3' and T3" on Fig. 2). Marine cliffs are $2-50 \mathrm{~m}$ high, and show two 285 fossil islands (Fig. 2A). Depending on the paleogeography, uplift rates and the 286 conservation of the landforms, the number of successive terraces observed in the 287 landscape at a given point can vary drastically. The maximum number of emerged 288 successive shorelines is 9 (not represented) including T3" and T3' (as on Transect 289 IV, Fig. 2C) but on transect III and V this number is reduced to 2 and 3, respectively.

\subsection{Mapping}

292

293 High-resolution topography (LiDAR) and surface classification models were used to 294 isolate remnants of marine terraces and rasas (Bowless and Cowgill, 2012). We used 295 swath profiles and semi-automated mapping of the surfaces associated with the 
296 marine terraces and rasas using 5 -m-resolution topography (DEM Litto 3D, details in 297 Nexer, 2015) combined with morphometric analysis. We developed a Surface 298 Classification Model (SCM) to recognize terraced levels, as in Bowless and Cowgill 299 (2012). Inputs into the model are the topographic slope and roughness, calculated 300 herein as in Burrough and McDonnell (1998) and Frankel and Dolan (2007), using a $30115 \times 15 \mathrm{~m}$ roving-window (Fig. $3 \mathrm{~A}-\mathrm{D}$ ). The surface roughness is regarded as the 302 standard deviation of slope of cells within the roving-window. Both topographic 303 parameters were clipped from histograms (Fig. 3 E and F), using $90 \%$ of the 304 distributions (15으 slope and 4 roughness). The values above these thresholds, 305 represented by gullies, valley slopes, and cliffs, are then removed to isolate the flat 306 and smoothed surfaces characteristic of rasas and marine terraces (Fig. 3 B - D).

307 Both truncated distributions were combined and normalized using a lineal equation 308 (Eq. 1) to create the SCM.

309

310

$$
\mathrm{SCM}=\left(\mathrm{SLP} / \mathrm{SLP} \_ \text {range }\right)^{\star} 0.5+\left(\mathrm{RGH} / \mathrm{RGH} \_ \text {range }\right)^{*} 0.5(\text { Eq. } 1)
$$

312 where SLP and RGH are the surface slope and roughness, and SLP_range and 313 RGH_range are the thresholds used to clip the topographic parameters. Then, the 314 SCM was intersected with the topography to obtain elevation distributions studied 315 using histograms and along profile projections. Marine terraces and rasas were 316 isolated through elevation bands in histograms (Fig. 3, 4B-C), where the limits of 
317 these bands in histograms represent their inner and outer edges (Bowless and 318 Cowgill, 2012).

319 Swath profiles were extracted perpendicular to terrace edges using TerraceM® 320 (Jara-Muñoz et al., 2016); the maximum distribution of elevations on swaths was 321 used to estimate the inner-edge (shoreline angle) elevations and for displaying the 322 elevation patterns of rasa levels identified by the SCM.

\subsection{Measurements of elevations}

326 We focused our field efforts on North Cotentin. There, as elsewhere, the elevations of

327 coastal landforms should be measured with reference to their modern counterparts,

328 instead of in relation to a hydrological sea level which corresponds to the Principal 329 Datum, characteristic of each country (Jardine, 1981; van de Plassche, 1986). The 330 hydrographic sea level in France (NFG, IGN-1969, Nivellement Général de la France 331 made by Institut Géographique National in 1969) is not sufficiently accurate for the 332 Cotentin Peninsula (see Coutard, 2003; Nexer, 2015). Consequently, for the 333 measurements of elevation from barometrical altimeters, we generally tied the 334 elevation measurements to the modern shoreline angle (break of slope between the 335 modern platform and the sea cliff) that correspond to the morphological sea level and 336 performed repeated measurements. We also measured the elevations of shoreline 337 angles with differential GPS (Global Positioning System), also repeatedly when 
338 possible. We used a Trimble Geoexplorer 2008 (horizontal and vertical precision of 1

$339 \mathrm{~m}$ ) and we made our measurements according to the French P.D. that was also tied 340 to the morphological sea level (Table 1). The Cotentin Peninsula area is macro-tidal 341 and we assume that the tide range remained steady through the period of time 342 covered by our study even if changes in coastal paleogeography such as those 343 evidenced herein may have induced changes in tidal amplitudes. We assigned an 344 error to each measurement depending on the preservation of fossil shorelines. These 345 errors increase with the elevation and degradation of the coastal indicators, from 1 $3462 \mathrm{~m}$ for the low-standing terraces to up to $10 \mathrm{~m}$ for the uppermost rasa.

\subsection{Sea-level curves used and uplift rates}

350 Several Quaternary sea-level curves have been derived from the isotopic and/or 351 geomorphic records (Waelbroeck et al., 2002; Lisiecki and Raymo, 2005; Siddall et 352 al., 2006; Zachos et al., 2008; Bintanja and Van de Waal, 2008; Rohling et al., 2009; 353 Murray-Wallace and Woodroffe, 2014). For each MIS, the sea-level curves vary by 354 several thousand years $(\mathrm{ka})$ in age and by several metres in height, that collectively 355 yield some inaccuracies when used (Caputo, 2007). Nevertheless, there is relative 356 consensus on the succession and ages of the most recent high-stands. 
358 The most commonly investigated high-stand in the geomorphological record is the 359 last interglacial period allocated to MIS 5 (e.g., Stirling et al., 1998; Murray-Wallace 360 and Woodroffe, 2014), and which includes three relative high-stands, MIS 5a (85 \pm 5 $361 \mathrm{ka})$, MIS 5c (105 $\pm 5 \mathrm{ka})$ and MIS 5e (128 ka to $116 \mathrm{ka})$. MIS 7 ranges from 190 to $362245 \mathrm{ka}$ (Thompson and Goldstein, 2005), and includes sub-stages 7a, 7c and 7e 363 (Dutton et al., 2009). Two sea-level high-stands occurred within MIS 9, sub-stages 9a 364 and 9c extending from $306 \pm 3$ ka to $334 \pm 4$ ka respectively $(\sim 324.5 \pm 18.5$ ka; 365 Stirling et al., 2001). MIS 11 lasted from 420 ka to 360 ka (Murray Wallace and 366 Woodroffe, 2014). Earlier interglacials are MIS 13 (480-530 ka), MIS 15 (560-620 ka) 367 and MIS 17 (650-720 ka; Thompson et al., 2003; Andersen et al., 2008; Murray368 Wallace and Woodroffe, 2014). Fewer agreements exist in regards of the position of 369 the sea level during Pleistocene high-stands with respect to present (i.e eustatic sea370 level) and the estimates vary drastically. We compared the values from the last global 371 compilation of geomorphic Quaternary sea-level indicators (Murray-Wallace and 372 Woodroffe, 2014) with five eustatic sea-level curves (Table 1). The curves selected 373 (Waelbroeck et al., 2002; Bintanja and Van der Wal, 2008; Grant et al., 2014; Shakun 374 et al., 2015; Spratt and Lisiecki, 2016) encompass different reconstruction methods, 375 cover the time-range of interest (since MIS 11, $420 \mathrm{ka}$ ), and have their uncertainties 376 quantified. Murray-Wallace and Woodroffe (2014) analysing considerable amount of 377 literature, proposed that MIS 5e, MIS 7, MIS 9, and MIS 11 sea level high-stands 378 were, respectively, $6 \pm 4 \mathrm{~m}$ higher, $-8 \pm 12 \mathrm{~m}$ lower, $3 \pm 2 \mathrm{~m}$ higher, and $9.5 \pm 3.5 \mathrm{~m}$ 379 higher than the modern sea level (Table 1). Waelbroeck et al. (2002) built a 380 composite relative sea-level curve over the last four climatic cycles from long benthic 
381 isotopic records retrieved at one North Atlantic and one Equatorial Pacific site. 382 Bintanja and Van der Wal (2008) used both ice-sheet and ocean-temperature models 383 to extract $3 \mathrm{Ma}$ mutually consistent records of surface air temperature, ice volume 384 and sea level from marine benthic oxygen isotopes. Grant et al. (2014) proposed a 385 chronology derived from a $\mathrm{U} / \mathrm{Th}$-dated speleothem $\delta^{18} 0$ record, for a continuous, 386 high-resolution record of the Red Sea relative sea level over five complete glacial 387 cycles ( $500 \mathrm{ka}$ ). Shakun et al. (2015) compiled 49 paired sea surface temperature388 planktonic $\delta^{18} 0$ records and extracted the mean $\delta^{18} 0$ of surface ocean seawater and 389 eustatic sea level over the past 800 kyr. Finally, Spratt and Lisiecki (2016) performed 390 principal component analysis on seven records from 0 to $430 \mathrm{ka}$ and five records 391 from 0 to 798 ka (Spratt and Lisiecki, 2016).

393 Based on previous dating and our elevation measurements for the Pleistocene 394 shoreline angle, we derived uplift rates for North Cotentin. Eustasy-corrected uplift 395 rates are given by dividing the difference between the elevation of the shoreline 396 angle of dated marine terrace and the eustatic sea level at the time of its formation by 397 the age of the terrace (Lajoie, 1986). We also calculated the apparent uplift rates that 398 neglect any a priori eustatic correction (as in Pedoja et al., 2011; 2014; Yildirim et al., 399 2013; Authemayou et al., 2017) (Table 1). 
403 To propose ages for the undated low-standing marine terraces, T2 to T4, on the 404 Cape de la Hague (NW Cotentin), we used a synchronous correlation method as in 405 Roberts et al. (2013). We attempted to estimate uplift rates by searching for the best 406 match between the measured elevations of the successive shoreline angles with 407 those obtained by extrapolating uplift rates to the entire sequence of landforms. This 408 method initially assumes constant uplift rate, but with the option to test varying uplift 409 rates over time (Roberts et al., 2013). The Terrace Calculator is initially driven by age 410 controls. We extrapolated a fixed uplift rate of $0.01 \mathrm{~mm} / \mathrm{yr}$ based on the Last 411 Interglacial Maximum (MIS 5e) dated terrace (122 $\pm 6 \mathrm{ka})$, present at elevations of $4125 \pm 1 \mathrm{~m}$. The output is the expected inner-edge elevations of the terraces allocated to 413 the high-stands from a chosen sea-level curve. These modeled shoreline angle 414 elevations are then matched against the measured one. Crucially, this method takes 415 into account re-occupation processes, i.e. old terraces can be erased by subsequent 416 high-stands, especially in a low uplifting area (e.g., Westaway, 1993; Roberts et al., 417 2013). Herein, the Terrace Calculator relies on the sea-level curves from Siddall et 418 al., (2003) for 0-410 ka and Rohling et al. (2014) from 410-980 ka in the form of sea419 level relative to present-day and high-stand ages. To compare with estimates from 420 other sea-level curves, we used data from: Murray-Wallace and Woodroffe (2014) 421 from 0-400 ka, Grant et al. (2014) from 0-480 ka, Waelbroeck et al. (2002) from 0- 
$478 \mathrm{ka}$ and Rohling et al. (2014) from 0 to $980 \mathrm{ka}$. Sea-level data from this latter

423 curve were also used to supplement the data within other models from their upper 424 age limits to $980 \mathrm{ka}$ (see section 3.1).

425

\subsection{Database on Western European strandlines}

427 We expanded on Pedoja et al. $(2011,2014)$ databases on Cenozoic sequences of 428 strandlines that focused on MIS 5e and MIS 11 high-stands (supplementary data 429 Table 1). Here, we also provide information about: 1) sites where some MIS 7 430 landforms are present but landforms allocated to MIS 5e are lacking (supplementary 431 data Table 2): and 2) Neogene fossil shorelines (supplementary data Table 3).

432

4334 Coastal uplift of the Cotentin Peninsula

434

435

\subsection{Distribution of the coastal sequences}

436

437 Our analysis reveals that the coastal sequences extend all over the Cotentin 438 Peninsula on a $>200-\mathrm{km}$-long coastal stretch (Fig. 4-6). Depending on the occurrence 439 of the lower part of the sequence (i.e. marine terraces), we subdivided the peninsula 440 into three areas (Fig. 4A). North Cotentin is circumscribed by the English Channel 
441 and the low-rising margin of the Seuil du Cotentin basin. South Cotentin is located

442 south of the Seuil du Cotentin basin. In between these two areas, in the Seuil du

443 Cotentin basin, no marine terraces are obvious in the landscape (Fig. 4A) but: 1)

444 interglacial coastal deposits have been described using data from a borehole (see

445 section 4.4.3.); 2) some rocky hills exhibit flat tops that we interpreted as shaped by 446 coastal erosion (emergence of rocky islets and platforms); and 3) surface 447 classification model shows that the Seuil du Cotentin basin is a flat area, with a mean 448 elevation similar to that of the low lying terraces present in North and South Cotentin 449 (Fig. 3, 4A-C).

\subsubsection{The lower marine terraces: $\mathrm{T} 1$ to $\mathrm{T} 4$}

453 Along the shores of $\mathrm{N}$ Cotentin, the lower part of the sequence is laterally continuous 454 over $\sim 110$ km (Fig. 4D), from Saint-Vaast-la-Hougue in the Val de Saire area (east), 455 to Carteret (west). Such successive low-standing marine terraces are lacking where 456 elevated sea-cliffs are present, i.e. between the Nez de Jobourg and the north of 457 Anse de Vauville (Fig. 1C, 4D). The terraces and their deposits are frequently capped 458 by thick Pleistocene heads and loess (as in the Baie d'Ecalgrain, Fig. 4A) or are 459 heavily reworked by human activities (urban area of Cherbourg, Fig. 4A, 4E). The 460 width of the low part of the sequence (T1 to T4 marine terraces) ranges from a few 461 tens of metres (for instance at Port Racine) to a maximum of $6 \mathrm{~km}$ (Val de Saire). 
462 The lower part of the sequence is the widest within the embayment (1 $\mathrm{km}$ at Urville 463 bay) and on Cape de la Hague $(1.5 \mathrm{~km})$. At the Cap de la Hague, from La Roche 464 (see Fig. 6A) to Port Racine, only the three lowest marine terraces are well 465 expressed in the landscape. T4 is locally present to the west (north of Auderville) as 466 a residual landform (paleo-peninsula or paleo-island?). Between Goury and Rocher 467 Gélétan (Fig. 5B), the lower strandlines have been eroded (i.e. formation of a low468 standing rasa). In the area, the 50 -to- 500 -m-wide $\mathrm{T} 1$ terrace has its distal edge at 5 $469 \pm 1 \mathrm{~m}$ NGF $(2 \pm 1 \mathrm{~m}$ above the modern shoreline angle; Table 1$)$. Its shoreline angle 470 culminates at $7 \pm 1 \mathrm{~m} \mathrm{NGF}$ ( $5 \pm 1 \mathrm{~m}$ above the modern shoreline angle). T2, as $\mathrm{T} 1$, is 47150 to $500 \mathrm{~m}$ wide. Its distal edge is present at an elevation of $10 \pm 2 \mathrm{~m} \mathrm{NGF}(7 \pm 2 \mathrm{~m}$ 472 above the modern shoreline angle) whereas its shoreline angle is present at $15 \pm 2 \mathrm{~m}$ 473 NGF (12 $\pm 2 \mathrm{~m}$ above the modern shoreline angle). On the Cap de la Hague (Fig. 5A474 B), T1 and T2 strandlines conform to the modern shoreline; fossil beach deposits and 475 fossil sea stacks are associated to this terrace at Rocher Geletan and Hâvre de 476 Bombec sites (Fig. 5B), for example. On the Cap de la Hague, we observed deposits 477 associated to $\mathrm{T} 1$ marine terrace at 23 sites. These deposits are either 0.5 to $1.5 \mathrm{~m}$ 478 thick layers of beach deposits comprised of a sandy matrix embedding sometimes 479 sorted centimetric to decimetric pebbles, suggesting only minor periglacial reworking, 480 and thinner deposits $(0.5 \mathrm{~m})$ of clay and silt with only a few metres of lateral extent. 481 These coastal deposits were reworked or capped by posterior periglacial processes 482 (solifluction) (Fig. 6B). T3 is 100 to $900 \mathrm{~m}$ wide and its distal edge is found at $17 \pm 2$ $483 \mathrm{~m}$ above the modern shoreline angle (20 $\pm 2 \mathrm{~m} \mathrm{NGF}$ ). The shoreline angle of T3 484 culminates at $22 \pm 3 \mathrm{~m}$ above the modern shoreline angle ( $25 \pm 3 \mathrm{~m} \mathrm{NGF}$ ). Its 
485 strandline does not conform to the modern one as it forms a fossil cape at the Rocher 486 Gélétan site (Fig. 5B). Finally, we infer the presence of T4 as a relict island or point 487 on the western side of the Cape de la Hague. The surface associated to T4 is 488 present at $\sim 33 \pm 3 \mathrm{~m}$.

489

\subsubsection{The upper rasas, $\mathrm{R} 1$ to $\mathrm{R} 4$}

491

492 All over the Cotentin Peninsula, we recognized four flat surfaces above the low493 standing marine terraces (Fig. 3 - 6). These surfaces are displayed over kilometres 494 and exhibit staircase morphology as they are separated by cliffs.

496 In $\mathrm{N}$ Cotentin, the sequence culminates at $185 \pm 10 \mathrm{~m}$ (see rasa 4 on Fig. 4D). The 497 toe of the cliffs separating the staircase surfaces (i.e. rasas 1 to 3 of this study) are 498 respectively found at $167 \pm 5 \mathrm{~m} 138 \pm 5 \mathrm{~m}$ and $86 \pm 5 \mathrm{~m}$ (Fig. 4E). We discard the 499 hypothesis that such surfaces are the results of long-term periglacial weathering of 500 pre-existing continental surfaces. In our opinion, such weathering is unlikely to 501 generate regular staircase surfaces with similar elevations for each step (i.e. each 502 rasa) all over the peninsula. On La Hague Point (not to be confused with the Cap de 503 la Hague, the northern tip of La Hague Point), some of these cliffs were interpreted 504 as fault scarps associated with a NW - SE fault (Font et al., 2002; Lagarde et al., 
505 2003). However, morphologic and morphometric evidence suggests that these 506 landforms are fossil sea-cliffs not fault scarps. i) These cliffs, present on the 507 interfluves, are continuous in the landscape and on the DEM and not only observed 508 on La Hague Point (Fig. 4). Each individual cliff exhibits a circular or oblong pattern. 509 From map view, the outline shape of successive cliffs most generally conforms to the 510 lowest one and defines a concentric circular, or oblong, staircase coastal landscape 511 as observed for example on La Hague Point, to the south of Cherbourg, or to the 512 east of Barneville-Carteret (Fig. 4A). Such geometries (Fig. 4A) are difficult to relate 513 to the geometry of faults. ii) The inner-edge elevations of the planation surfaces 514 suggest that there are no elevation offsets at both sides of the Hague Point (Fig. 7A, 515 B) indicating that no tectonic movements took place along a purported fault running 516 along the elongated top of the Hague Point. In addition, we compared cliff heights 517 and their corresponding inner-edge elevations of each rasa level obtaining positive 518 correlations (Fig. 7C). Following the criteria proposed by Jara-Muñoz et al., (2017), 519 positive correlation suggests that these scarps were formed by the effect of coastal 520 erosion and uplift. In contrast, fault scarps usually characterized by negative or no 521 correlation. iii) Tectonic displacement due to this purported fault has been evoked to 522 explain the difference of elevations of the MIS 7 deposits at Ecalgrain and the MIS 5e 523 deposits on La Hague Point. Recent dating of the Ecalgrain deposits suggest a 524 reworking of MIS 7 deposits on the MIS 5e platform (i.e. re-occupation) (Cliquet et al., 525 2009; Cliquet, 2015) which does not imply any activity of the purported fault. 
527 In coastal areas, staircase flat surfaces with a circular or oblong pattern of the

528 successive cliffs are interpreted as the uplift and emergence of an island that further

529 coalesced with the nearby mainland (e.g., Szabo and Wedder, 1971; Lajoie et al.

530 1991; Pedoja et al., 2006 a,b; 2014; Authemayou et al., 2017). Hence, we interpret

531 the staircase planation surfaces of the Cotentin peninsula as rasas with their

532 associated shoreline angles.

533

534 In S Cotentin (Fig. 4F), the shoreline angles of the rasas R1 to R3 were found at

535 similar elevations within the error range of measurements to that of $\mathrm{N}$ Cotentin: $83 \pm$

$5365 \mathrm{~m}, 136 \pm 5$, and $167 \pm 5 \mathrm{~m}$. Rasa 1 is best observed south of Avranches where it

537 constitutes wide surfaces $(>3 \mathrm{~km})$. Rasa 2 is the most extensive surface in the area

538 (width reaching $10 \mathrm{~km}$ ) and Rasa 3 is morphologically better developed than in $\mathrm{N}$

539 Cotentin. Rasa 4 caps the highest parts of the S Cotentin Peninsula with its distal

540 edge at $174 \pm 5 \mathrm{~m}$ and its inner edge at $200 \pm 5 \mathrm{~m}$. The strandlines demonstrate a

541 convex segment of the coast (i.e. paleo-capes) locally interrupted by narrow

542 embayments, such as that observed east of Avranches.

543

544

4.2 Paleogeographical evolution

545 
546 The distribution of the fossil strandlines in Cotentin provides strong evidence for the

547 emergence and coalescence of various rocky islands and islets, i.e. a rocky 548 archipelago, to form a bigger island that latter connected to the mainland through the

549 closure of the "Seuil du Cotentin" seaway. Such evolution began with the uplift of 550 rocky reefs and platforms to form the first islands of the archipelago. The size of such

551 islands typically ranges from few tens of metres to few kilometres with various 552 shapes; La Hague fossil island is oblong whereas La Boissais fossil island is more 553 circular. Such rocky platforms and low-lying islands compare with the modern 554 Chausey archipelago (Fig. 1B). Subsequently, the uplift concerns larger, flat rocky 555 islands bordered by shore platforms comparable to Alderney Island (Fig. 1B). The 556 islands further expand in size by the formation of successive rasas, and latterly, 557 marine terraces leading to larger and higher islands (as in Fig. 2) comparable to 558 Guernsey or Jersey where elevated marine terraces are also known (see Fig. 1B, 559 Renouf and James, 2011). Neighbouring rocky platforms result in the coalescence of 560 various elevated islands: six on N Cotentin and two overlooking the SW side of the 561 Seuil du Cotentin Basin (Fig. 4D). Through the closure of the Seuil du Cotentin 562 seaway, the $\mathrm{N}$ Cotentin main island (Rasa 1 ) was connected with the landmass, to 563 form the Cotentin Peninsula. This evolution is somehow schematic owing to the 564 interplay of tectonics, continental and marine erosion during earlier times, including 565 terrace re-occupation processes or, in theory, the emergence of terraces formed 566 during sea-level low-stands. 
568 In summary, in $\mathrm{N}$ Cotentin the strandlines associated with the rasas define fossil 569 rocky islands and islets, while to the south of the Peninsula they define the 570 landmasses at the time of the emergence of the northern islands. We did not find

571 Cenozoic marine deposits associated with the rasas but they have been described 572 both to the north and south of the Peninsula (section 2.2).

\subsection{Upper Pleistocene (MIS 5e) uplift rates revisited}

576 We focused on dated terraces for which the elevations of the shoreline angles are

577 measured directly above their modern counterparts and calculated uplift rates for the 578 MIS $5 e$ benchmark in $\mathrm{N}$ Cotentin. At various sites, its elevation above its modern 579 counterpart $(\sim 5 \pm 1 \mathrm{~m})$ implies an apparent uplift rate of $0.04 \pm 0.01 \mathrm{~mm} / \mathrm{yr}$ (Table 1). 580 The mean eustasy-corrected uplift rates have large margins of error (Table 1). 581 Depending of the sea-level data used, their mean values can be either: i) slightly 582 negative: $-0.01 \pm 0.04 \mathrm{~mm} / \mathrm{yr}$ (data from Murray-Wallace and Woodroffe (2014)), ii) 583 neutral: $0.00 \pm 0.11 \mathrm{~mm} / \mathrm{yr}$ (data from Waelbroeck et al. (2002) or $0.00 \pm 0.13 \mathrm{~mm} / \mathrm{yr}$ 584 (data from Spratt and Lisiecky (2016)) or iii) positive: $0.04 \pm 0.08 \mathrm{~mm} / \mathrm{yr}, 0.13 \pm 0.12$ $585 \mathrm{~mm} / \mathrm{yr}$ and $0.01 \pm 0.12 \mathrm{~mm} / \mathrm{yr}$ (data from Bintanja and Van Der Wal (2008), Shakun 586 et al. (2015) and Rohling et al. (2014) respectively). As previously noted for the 587 sequence of NE Cotentin, subsidence is unlikely since the coastal staircase 588 morphology is clearly associated with uplift (Coutard et al., 2006). For T1 and T2, an 
error of $\pm 12 \mathrm{~m}$ for the predicted elevations for each high-stand is directly taken from

590 Siddall et al. (2003). T3 and T4 have a higher error of $35 \mathrm{~m}$ as per the discussion in 591 Rohling et al. (2014). As some of these errors are larger than the elevations of the 592 terraces used, we applied statistical testing to interpret the relationship between a set 593 of predicted elevations versus measured elevations (see below).

594

595 Whichever correction is applied, Upper Pleistocene coastal uplift rates are low to very 596 Iow (< 0.2 or $<0.1 \mathrm{~mm} / \mathrm{yr}$, respectively, as in Pedoja et al. (2011)) as observed 597 elsewhere along the Western European coasts (section 5.3) or along other passive 598 margins (Pedoja et al., 2014).

599

600

\subsection{Possible timings for the emergence of the Peninsula}

601

602 To obtain a chronological framework for the undated landforms, we postulated steady 603 uplift rates (Lajoie, 1986), although this is unlikely at the timescales considered. We 604 extrapolated three possible rates derived from: (i) the elevation of the dated MIS 5e 605 terrace; (ii) the elevations of T2 to T4 allocated to MIS 7, 9 and MIS 11 (short lasting 606 hypothesis, as in Coutard et al., 2006) (Fig. 8A) and; (iii) modelling of the lower 607 sequence (long lasting hypothesis, Fig. 8B, 9). These are further explored below. 
610

611 In N Cotentin, the "standard method" (Table 2) which sequentially correlates each 612 subsequently higher terrace to the next older high-stand, consists of the allocation of 613 T2, T3 and T4 to MIS 7, MIS 9 and MIS 11, respectively (as in Coutard et al., 2006). 614 It results in homogeneous apparent uplift rates $(\sim 0.06 \pm 0.03 \mathrm{~mm} / \mathrm{yr}$; Table 2$)$. When 615 corrected for eustasy, variations in the uplift rates are clear and show an increase of 616 uplift during the penultimate interglacial whatever the correction applied (Table 2, Fig. 617 8A). Consequently, we extrapolated a mean MIS 5e apparent uplift rate of $0.04 \pm$ $6180.01 \mathrm{~mm} / \mathrm{yr}$, and a mean "high" Middle Pleistocene eustasy-corrected of $0.09 \pm 0.03$ $619 \mathrm{~mm} / \mathrm{yr}$ (Table 3).

620

621 On N Cotentin, rasa 4 caps the paleo-islands of La Hague and La Boissais at 622 elevations of $185 \pm 10 \mathrm{~m}$ (Fig. 8A). Both islands would have emerged at $5 \pm 1.5 \mathrm{Ma}$ 623 (apparent) or $2.9 \pm 0.9 \mathrm{Ma}$ (eustasy-corrected) (see Table 3 for the possible age of 624 formation of the other rasas). In summary, the short-lasting hypothesis suggests a 625 Pliocene onset of the sequences preserved on the peninsula.

626

627

\subsubsection{Long-lasting hypothesis}

628 
629 Synchronous correlation modelling (as in Roberts et al., 2013) suggests that a 630 constant uplift rate of $0.01 \mathrm{~mm} / \mathrm{yr}$ (Table 4) would be responsible for the formation 631 and preservation of the four low terraces (T1-T4) on N Cotentin. The shoreline angle 632 of the last interglacial maximum $\mathrm{T} 1$ marine terrace is found at $\sim 5 \pm 1 \mathrm{~m}$ above its 633 modern counterpart and has a predicted elevation of $6 \mathrm{~m}$. Modelling suggests that T2 634 (at $12 \mathrm{~m}$ ) would be correlated with the 340 ka high-stand (MIS 9c, predicted to be at 8 $635 \mathrm{~m})$. T3 (at $22 \mathrm{~m}$ ) would be allocated to either the MIS 13 (525 ka) or MIS 15 (620 ka) 636 high-stand predicted to be both at $26 \mathrm{~m}$ (Table 4, Fig. 8B and 9). Finally, T4 (at $33 \mathrm{~m}$ ) 637 would be assigned to the $980 \mathrm{ka}$ high-stand predicted to be at $35 \mathrm{~m}$. The modelling 638 suggests reoccupation processes for the high-stands between MIS 5e and MIS 9c, 639 as well as for those between MIS 9c and MIS 15 (numbers in grey scale, Table 4). 640 Such processes, symptomatic of low uplift, have also been observed at Menez 641 Dregan (W Brittany, Table 1 supplementary data) where both MIS 5e and MIS 11 642 coastal deposits are present on the same terrace. In our analysis, T2 was allocated 643 to the MIS 11 high-stand using eustasy-correction from either Waelbroeck et al. 644 (2002) (predicted to be at $10 \mathrm{~m}$ ) or Murray-Wallace and Woodroffe et al. (2014) 645 (predicted to be at $14 \mathrm{~m}$ ). As sea-level data from these curves does not extend 646 beyond $478 \mathrm{ka}$, the allocations of T3 and T4 did not alter when they were tested. We 647 assessed the relationship between the predicted and measured elevations using a 648 non-parametric method - Pearson's correlation coefficient with an output of $r=0.99$, 649 approaching the ideal value of 1 (Fig. 9A). This indicates a robust correlation 650 between multiple strandline elevations and multiple sea-level high-stands, which 651 would imply that uplift rates have not varied over the last $0.5 \mathrm{Ma}$. 
652 We compared the RMS deviation of all uplift rates scenarios from 0 to 0.11 in 653 intervals of 0.005 in order to assess the accuracy of the constant uplift rate we

654 obtained from the dated shoreline (Fig. 9B). An uplift rate of $0.01 \mathrm{~mm} / \mathrm{yr}$ constant 655 over $\sim 1$ Ma provides the best fit uplift rate to model the coastal sequences of the 656 Cotentin Peninsula (Fig. 9B). Extrapolating such a rate yields that Rasa 4 would have 657 emerged at $18.5 \pm 1 \mathrm{Ma}$, Rasa 3 at $16.5 \pm 0.5 \mathrm{Ma}$, Rasa 2 at $13.8 \pm 0.5 \mathrm{Ma}$ and Rasa 6581 at $8.6 \pm 0.5 \mathrm{Ma}$ (Table 3, Fig. $8 \mathrm{C}$ ). Assigned rasa ages are in good agreement with 659 Neogene-aged high-stands (Miller et al., 2005). R4, R3 and R2 would record the 660 following highstands; 17.5-18.5 Ma (early Miocene), 14.5 Ma (middle Miocene), 66113.5 - $12 \mathrm{ka}$ (late Miocene). Finally, R1 would be the morphological expression of the 662 intensification of the sea-level oscillations during the late Miocene-Pliocene and early 663 Pleistocene.

664 In short, the long-lasting hypothesis emphasizes an early Miocene onset of the 665 coastal sequence preserved on the Cotentin Peninsula.

666

\subsubsection{Age of the onset of the coastal sequences?}

668

669 Both uplift hypothesis (i.e. short versus long-lasting) fit with previous descriptions of

670 Miocene and Pliocene coastal deposits overlying the rasas (see section 2.1). The

671 combination of hypotheses results in a very large age range. Rasa 4 would have 
672 emerged between 1.5 and 19.5 Ma considering all the errors within the extrapolation

673 (Table 3).

674

675 The timing of the closure of the seaway that once formed the Seuil du Cotentin area 676 provides crucial data to assess the age of the coastal sequences located in its 677 vicinity. Based on boreholes and sparse outcrops, the thickness of the marine to 678 fluvial sediments deposited in the Seuil du Cotentin basin is estimated to be $>150 \mathrm{~m}$.

679 The sediments consist of clastic deposits with conglomerates and peat at the top of 680 the formation. The depositional environments of the succession change from marine 681 to fluvial and represent two transgression-regression cycles (Dugué, 2003). In many 682 studies (Clet-Pellerin et al., 1997; Garcin et al, 1997; Dugué et al., 2007, 2009) this 683 sequence is interpreted as being deposited during Late Pliocene to Early 684 Pleistocene. The first transgression identified is referred to as the "Brunssumian685 Reuverian", which approximates to the whole Pliocene and the associated deposits 686 are now found offshore in the English Channel (Dugué, 2003). The second 687 transgression is proposed to be Lower Pleistocene (Tiglian, 2.4-1.8 Ma) associated 688 with the Sable de Saint Vigor Formation. Clet-Pellerin et al. (1997) proposed an age 689 of 1.45 - 1.2 Ma (MIS 34 - 36) in comparison with other European sites. However, the 690 exact correlations between these local stages and the international chronological 691 stages remain unknown. More recently, van Vliet-Lanoë et al. (2002) proposed for 692 the Sable de Saint Vigor, through direct Sr dating, a Zanclean (Pliocene) age for the 693 formation. 
695 At this stage, more dating is needed to better constraint the timing of the onset of the 696 coastal sequences preserved on the Cotentin Peninsula.

697

698

\section{Late Cenozoic uplifting coastal sequences of Western Europe}

699

700 Early descriptions of marine terraces and raised beaches arise from the English

701 Channel shores mostly because low-standing coastal deposits and overlying 702 continental cover both contain flints and extinct mammal bones (e.g Lyell, 1830; 703 Moore, 1842; Chambers, 1848; Prestwich, 1862-1863; Breuil et al., 1942). Early 704 syntheses on sequences of strandlines dealt with Western Europe and more 705 specifically with sites in western France and southern England (e.g., Barrell, 1915; 706 Depéret, 1918-1922; Daly, 1925; Wythe-Cooke, 1930; Bull, 1941; Baden-Powell, 707 1954; Guilcher, 1969). This area is rather neglected in recent global synthesis on sea 708 - level changes (e.g. Pedoja et al., 2014; Murray-Wallace and Woodroffe, 2014).

709

710 Out of 180 references (supplementary data Tables 1, 2, 3), we evidenced: 1) 169

711 sequences embedding the MIS 5e benchmark (99 sites in Pedoja et al. 2014), 2) two 712 sequences including coastal landforms and deposits correlated to MIS 7 but no 713 strandline correlated to the last interglacial maximum (MIS 5e), 3) 14 sequences 
714 including the MIS 11 shoreline; and 4) 21 sequences including some Neogene 715 strandlines.

717 At any coastal site, current elevations of the Holocene and Pleistocene terraces 718 depend on the combination of glacio-isostatic adjustment (GIA), tectonics and other 719 local processes (Shennan and Horton, 2002; Milne et al., 2005). In France, Spain 720 and Portugal, the lack of accurate Holocene sea-level index points precluded the 721 establishment of Holocene sea-level curves but recent advances have been made 722 from the analysis of submerged deposits in estuaries (e.g., Leorri et al., 2012). 723 Lambeck, (1991; 1996) and Shennan and Horton, (2002) constrained Late 724 Pleistocene and Holocene relative sea level changes in the British Isles and provided 725 estimates of current land-level changes (negative of relative sea-level change). 726 Maximum relative land uplift occurs in central and western Scotland, at $\sim 1.6 \mathrm{~mm} \mathrm{yr}^{-1}$, 727 and maximum subsidence is in southwest England, at $\sim 1.6 \mathrm{~mm} \mathrm{yr}^{-1}$. As our aim is to 728 evidence the Neogene - Quaternary tectonic uplift of western European coasts, we 729 do not consider, in our interpretation, sequences located in areas where fast GIA 730 dominates the signal, as evidenced by Lambeck, $(1987 ; 1991)$ and Shennan and 731 Horton, (2002; see dotted line Fig.10A). In area where the last GIA is inducing 732 subsidence (i.e. Southern England), tectonic uplift is lowered. Of course such 733 quantifications only concern the period following the last glacial (MIS 2). In the case 734 of MIS 5e marine terraces, two joint corrections could be applied because one should 735 ideally compare the shape of the Earth deprived of GIA, therefore compare a GIA- 
736 relaxed MIS 5e (i.e. without any GIA from the previous deglaciation stage MIS 6),

737 with a present-day GIA-relaxed Earth. This lack of knowledge on Middle Pleistocene

738 GIA prevents correcting MIS5e uplift rates. Consequently for the British Isles, we

739 discarded 64 sites (underlined in grey on supplementary Table 1) where older, Middle

740 Pleistocene, highstands (MIS 7, 9, MIS 11) are absent and where MIS5e is not

741 embedded within a longer lasting sequence.

743 At many sites along the coasts of Spain, Portugal and France, sequences are 744 morphologically similar to that of Cotentin: low-standing, rather well-individualized

745 fossil rocky strandlines, overlooked by older, wider rasas. In NW Portugal (Minho 746 area), five marine terraces reach $65 \pm 5 \mathrm{~m}$ in elevation and are overlooked by a rasa 747 culminating at $100 \mathrm{~m}$ (e.g., Texier and Meireles, 1987). In France, within the Brest 748 embayment (Feunteunaon site Table 1 Supplementary data), a sequence of six 749 terraces and rasas reach 135 m in elevation (Guilcher, 1974; Hallégouët, 1976). 750 Fossil landforms frequently consist in rocky shore platforms with associated deposits 751 (e.g., rasa and marine terraces), sea caves with coastal deposits (e.g. Sutcliffe et al., 752 1987), or fossil depositional landforms such as the Plovan beach ridge (Guilcher and 753 Hallégouët, 1981). Most sequences are strongly affected by continental erosion. 754 Remnants of marine terraces and rasas, preserved on the interfluves, are often 755 capped by continental deposits: heads and loess to the north (e.g., Regnauld et al., 756 2003), aeolian and alluvial deposits to the south (e.g., Teixeira, 1944). In Spain and 757 Portugal, rasas are obvious in the landscape and frequently include coastal deposits. 
758 In France, rasas are more dissected and show fewer deposits that are often azoic.

759 Rasas, whether sedimentary (e.g., Portugal, see Cunha et al., 2015a, 2015b) or

760 erosive, are more intensely dissected by fluvial erosion than younger marine terraces

761 (for instance in the Pays de Leon, Brittany, e.g., Hallégouët, 1976). Within estuaries,

762 sequences are composite, made of both marine and fluvial terraces, as observed in

763 Portugal (e.g., Ramos et al., 2012), Spain (Moreno and Mediato, 2009), France (e.g.,

764 Hallégouët, 1976) or England (Westaway et al., 2009).

765

766 Dating indicates that the lowest standing coastal landforms were formed during MIS

767 5e high-stand (Table 1 supplementary data) for which we compiled its elevation at

768169 sites. Two studies propose a different morpho-stratrigraphy for some marine

769 terraces deposits in Portugal and Spain. On the basis of ${ }^{14} \mathrm{C}$ and OSL dating,

770 Benedetti et al. (2009) correlated some of the low-standing terraces in Estremadura

771 (Portugal) to MIS 3 and 4. Through ${ }^{14} \mathrm{C}$ dating, González-Acebrón et al., (2016) also

772 correlated low-standing terraces to MIS 3 in southern SE Spain, next to Cadiz. We

773 discard these results since they are not benchmarked on the same MIS 5e, MIS 11 or

774 older sea level high-stands that we consider herein.

775

776 At two sites, strandlines older than MIS $5 e$ are present whereas MIS $5 e$ is lacking

777 (Fig. 10B and Table 2 supplementary data). At Sangatte (N France), long-recognized

778 coastal deposits and morphologies (e.g., Prestwich, 1851, 1865; Baudet, 1959), were 
779 dated by OSL and correlated to MIS 7 (Balescu et al., 1992), but the sedimentary

780 coastal sequence could also include MIS 9 deposits (Sommé et al., 1989; 1999). At

781 Easington (Eastern England), in an area affected by post glacial rebound (uplift)

782 raised beach deposits associated to a fossil strandline were dated by OSL and

783 amino-acid racemization and correlated to MIS 7 high-stand (Davies et al., 2009).

784 Older dated geomorphic markers consist in MIS 11 strandlines, described at 14 sites

785 (Table 1 supplementary data). Finally, rasas overlook individualized strandlines at 21

786 sites (Fig. 10C, Table 3 supplementary data). At a limited number of sites in SW

787 Europe, marine deposits or marine surfaces associated with the rasas have been

788 dated (Fig. 10C, Table 3 supplementary data). The dating is absolute $\left({ }^{10} \mathrm{Be} ; \mathrm{Sr}\right)$ as for

789 the Rasa of Cerro da Boa Viagem (Portugal) or the 60 -m-high rasa of Cantabria

790 (Spain) or relative (biostratigraphy, geometry of discordance, etc.) (Table 3

791 supplementary data). A Miocene (Aquitano-Langhense) onset is proposed for the

792 sequence of central and western Asturias (Spain) where the highest rasa has an

793 elevation of $264 \mathrm{~m}$ and $180 \mathrm{~m}$ respectively (Table 3 supplementary data). In Portugal,

794 the onset of the sequences is proposed to be Pliocene (Table 3 supplementary data,

795 sites Serra da boa Viagem, Lavos-Alqueidao, Maiorca - Vila Verde or Cabo Espichel

796 for example). Comparison with similar sites around the world shows that Pliocene or

797 Miocene ages for the initiation of some coastal sequences are still discussed, for

798 example in Casablanca (Morocco, Raynal et al., 1999). 
800 Within the studies compiled, elevation measurements are generally provided above 801 the Principal Datum of the considered country (e.g., NGF for France, O.D. for 802 England; see section 2.2). Yet, studies where elevations measurements are 803 discussed are scarce (e.g., Arkell, 1943; Alonso and Pages, 2000; Coutard et al., 804 2006; Figueiredo et al., 2013).

805

806 At various sites, the mean elevation of the shoreline of the last interglacial maximum 807 stands within estimates for the eustatic range of MIS 5 e sea level with respect to 808 present-day (Siddall et al., 2006; Kopp et al., 2009; Rohling et al., 2009). However, in 809 Western Europe as elsewhere (Pedoja et al., 2014; Authemayou et al., 2017), MIS 5e 810 marker is always embedded within a staircase coastal sequence, a morphology that 811 cannot be explained in the absence of regional uplift.

813 Excluding areas affected by fast GIA, in our database, the elevation of MIS $5 \mathrm{e}$ 814 benchmark ranges from $-2 \pm 1 \mathrm{~m}$ (site Le Havre, France, Breton et al., 1991) to 19.5 $815 \pm 1 \mathrm{~m}$ at Tarifa (Atlantic Southern Spain, Zazo et al., 1999) with a mean of $6.2 \mathrm{~m} \pm$ $8161.6 \mathrm{~m}$ (Table 3 supplementary data). Elevations of Middle Pleistocene MIS 11 817 landforms range from $8 \pm 3 \mathrm{~m}$ to $33 \pm 4$ (mean $20 \pm 2.5 \mathrm{~m}$ ). Consequently, upper 818 Pleistocene (MIS 5e) apparent uplift rates range from $-0.016 \pm 0.008 \mathrm{~mm} / \mathrm{yr}$ to $0.16 \pm$ $8190.01 \mathrm{~mm} / \mathrm{yr}$ with a mean of $0.05 \pm 0.01 \mathrm{~mm} / \mathrm{yr}$ (Fig. 10A). Apparent Middle 820 Pleistocene uplift rates range from $0.02 \pm 0.01$ to $0.08 \pm 0.02 \mathrm{~mm} / \mathrm{yr}$ (mean $0.05 \pm$ 
$8210.01 \mathrm{~mm} / \mathrm{yr}$ ) (Fig. 10B). The modern elevation of rasas indicates long-term tectonic 822 uplift of Western Europe (Spain, Portugal, France, and possibly UK and Ireland) as 823 such landforms cannot be explained by the sole effect of eustasy. Mean apparent 824 long-term uplift rates are $\sim 0.01 \mathrm{~mm} / \mathrm{yr}$, (Table 3 supplementary data, Fig. 10C) and 825 are consistent with previous estimates of $\sim 90 \mathrm{~m}$ of Pleistocene uplift from fluvial 826 incision measurement in the coastal area (ca. $0.03 \mathrm{~mm} / \mathrm{yr}$; Bonnet et al., 2000; Brault 827 et al., 2004).

828

829 Pleistocene and Neogene coastal uplift rates of Atlantic Europe are low to very low ( 8300.01 to $0.2 \mathrm{~mm} / \mathrm{yr}$, as in Pedoja et al., 2011) and rather uniform over the studied 831 zone, though with local exceptions that we cannot address without further dating 832 (e.g., MIS 7 at Sangatte, see Table 1 supplementary data). At first glance, the 833 convergence between Eurasia and Africa induces more intense deformation to the 834 south in southern Spain and Portugal (e.g see Ingrina or Conil-Trafalgar data, Table 8351 supplementary data). But, before any detailed interpretation, these data need to be 836 refined especially for rasa sites where deposits are present.

838 Our findings are in line with earlier studies that suggest that a Neogene tectonic 839 event affected most continental margins of Atlantic Europe, and reached far into the 840 European craton (e.g., Japsen and Chalmers, 2000). Similar vertical movements are 841 reported for other continental margins (e.g., Japsen et al., 2006; Bonow et al., 2009), 
842 and are not unique to the Late Cenozoic (Peulvast et al., 2008; Bertotti and Gouiza,

843 2012). These facts taken together call for a common underlying process. These

844 anomalous vertical motions ought to have a large-scale tectonic origin, regardless of

845 the subjacent proposed mechanism, which remains a matter of debate. Possible

846 mechanisms are igneous underplating (Brodie and White, 1994), asthenospheric

847 upwelling, isostatic readjustments due to glacial erosion and regional compression of

848 the lithosphere (e.g. Japsen and Chalmers, 2000; Yamato et al., 2013). We favour

849 the latter for it fits with the large-scale distribution of the coastal uplift evidenced from

850 southern Spain to Northern Ireland (Fig. 1A, 10). In an attempt to reframe the Atlantic

851 coastal uplift of Europe in its entirety, we emphasize that, alike mountain belts

852 worldwide, uplifting coasts of western Europe are symptomatic of the generalized

853 lithospheric compression that increased during the Cenozoic (Yamato et al., 2013).

854 Collisions at far-field plate margins overall increase compression in lithospheric

855 plates; tectonic inversion, and uplifting continental margins reveal this augmenting 856 stress regime worldwide (Pedoja et al., 2011; Japsen et al., 2012; Yamato et al., 857 2013). Similar regional illustrations are found in Greenland (e.g., Døssing et al., 858 2016), southern Africa (Green et al., 2016), or Brazil (Japsen et al., 2012). Ultimately, 859 this compression is induced by mantle convection underneath tectonic plates 860 (Yamato et al., 2013; Husson et al., 2015; Walker et al., 2016) and is most probably 861 expressed through the widespread Neogene and Quaternary sequence of coastal 862 landforms (marine terrace rasas) found along the shores of Western Europe. 


\section{Conclusion}

865

866 On the Cotentin Peninsula, the typical coastal sequence culminates at $\sim 200 \mathrm{~m}$ and

867 includes up to four low-rising, clearly distinguished marine terraces overlooked by up

868 to four rasas. Based on previous dating of the last interglacial maximum (MIS 5e)

869 marine terrace in N Cotentin, as well as on modelling, we derived: 1) a mean Upper

870 Pleistocene (MIS 5e) apparent uplift rate of $0.04 \pm 0.01 \mathrm{~mm} / \mathrm{yr} ; 2$ ) a mean "high"

871 Middle Pleistocene eustasy-corrected of $0.09 \pm 0.03 \mathrm{~mm} / \mathrm{yr}$ and 3) a low constant

872 uplift rate of $0.01 \mathrm{~mm} / \mathrm{yr}$ using a synchronous correlation approach. Extrapolation of

873 these rates reveals that the onset of the sequence of $N$ Cotentin Peninsula started

874 between $\sim 3 \mathrm{Ma}$ and $\sim 15 \mathrm{Ma}$ ago. The palaogeographic evolution of the Cotentin

875 Peninsula (Normandy, France) corresponds to the emergence of rocky islands and

876 islets that gradually merged together, and thereafter to the continent, ultimately

877 forming a peninsula. Furthermore, through compilation of former data, we highlight

878 that such morphostratigraphy - Pleistocene terraces overlooked by widespread Mio-

879 Pliocene rasas - is representative of Western Europe (except the British Isles) and, to

880 a larger extent, is related to the generalized Cenozoic compression that accompanies

881 the convergence between Africa and Eurasia. 
883 Acknowledgments: We thank the ANR GiSeLE as well as the INSU programme 884 Sulamer Hople for funding. This research is in memoriam of Jean Pierre Lautridou 885 who has shown the coastal sequences of North Cotentin to many of us.

Figure Captions

Figure 1: Index map A) Location of the Cotentin Peninsula in W Europe B) Coastal sequences in Normandy and Northern Brittany. Stars represent sites where a 891 sequence of coastal landforms (marine terraces, raised beaches) includes the MIS 892 5e benchmark (data from Pedoja et al., 2011, 2014, see Table 1 supplementary 893 data). C) Location of Plio-Pleistocene basins on the Cotentin Peninsula. Extents of 894 Plio-Pleistocene basins from Dugué (2003). 1 Larmor-Pleubian, 2 Brehat, 3 Binic, 4 895 Cesson, 5 Port Morvan, 6 Dahouet, 7 Piegu, 8 NE Saint Malo, 9 Hacqueville, 10 896 Hauteville - Annoville, 11Chausey, 12 Jersey, 13 and 14 Guernsey SE and W. 15 le 897 Rozel, 16 Alderney, 17 St Martin Jerd'heux, 18 Val de Saire, 19 Grandcamp Maisy, 89820 St Côme - Asnelle - Meuvaine, 21 Graye, 22 le Havre. Is Island. Ar Archipelago. 899 LM La Mondrée submerged terrace. SV Saint Sauveur le Vicomte. SM Sainteny 900 Marchésieux. Stars : coastal sequences including the MIS 5e landforms (Pedoja et 901 al., 2011; 2014). Line : uplifted coastal stretch (Pedoja et al., 2014; this study). 
903 Figure 2 : Idealized staircase coastal landscape. A) Sequence of marine terraces

904 and rasas. B) Detail of a single marine terrace. C) Elevation transects.

905

906 Figure 3 : Extent of the high-resolution topography and results of the regional 907 morphometric analysis. A) Shaded topography and high-roughness patches 908 identified using the Surface Classification Model (SCM). B-C) results of surface 909 classification model SCM D-E) Example of SCM classification and mapping of marine 910 terrace surfaces. E-F) Histograms of slope and roughness used to calibrate the SCM, 911 selected ranges include $90 \%$ of the data.

912

913 Figure 4: The coastal sequences of the Cotentin Peninsula. A) Surface classification 914 model displaying flat surfaces interpreted as sequences of marine terraces and 915 rasas. B - C) Histogram of elevation v/s surface of SCM patches of N and S Cotentin. 916 Levels are defined using elevation ranges, the width of each band represent the 917 position of the outer and inner edge of marine terraces and rasas. D) Schematic 918 mapping of North Cotentin marine terrace and rasas. E) - F) Swaths profiles across 919 the Cotentin Peninsula, north and south, respectively. 
921 Figure 5: Coastal sequence at Point and Cape de La Hague. A) General mapping B)

922 Detailed mapping C) GPS Profile

923

924 Figure 6: Interpreted pictures of the sequence in N. Cotentin A) Low-standing T1

925 terrace at Goury B) Rasa and covered sequence of Ecalgrain Embayment C) Low926 standing terrace at Anse de Vauville.

928 Figure 7: Morphometry of the rasa surfaces at La Hague Point. A) Surface 929 classification model and swath profiles (black rectangles) used to map inner edges 930 (black dots). B) Box plot of inner edge elevations for each rasa at both sides of La 931 Hague Point. Dashed lines indicate the mean elevation. Notice that the difference 932 between inner edges at both sides of the ridge is less than $2 \mathrm{~m}$. C) Scatter plots of 933 cliff height versus inner edge elevations of each rasa. Red line is a lineal regression 934 and associated correlation coefficient $\left(R^{2}\right)$, notice positive slope suggesting that 935 these cliffs were formed by sea erosion (see text for further details).

936

937 Figure 8: Hypothesis on the timing of formation of the sequence from $\mathrm{N}$ Cotentin A) 938 The sequence with dated terrace and elevations of the strandlines B) the short939 lasting hypothesis : Pliocene onset of the Cotentin coastal sequences $\mathbf{C}$ ) the long940 lasting hypothesis: Miocene onset of the Cotentin coastal sequences. 
942 Figure 9: Synchronous correlation method applied to the four (T1 to T4) low-standing

943 terraces in Cotentin. Methods as in Roberts et al., 2013. A) Predicted versus

944 measured elevations of the shoreline angle of the low-standing marine terraces of $\mathrm{N}$

945 Cotentin B) Uplift rates and RMS deviation

946

947 Figure 10: Coastal uplift of Western Europe A) MIS 5e. The dotted line represent for

948 the British Isles, the frontier between uplifting coasts (to the north) and subsiding

949 coasts (to the south), for the period of time $0-6$ ka as in Lambeck, $(1991 ; 1996)$ and

950 Shennan and Horton, (2002). see text for more details B) MIS 11 and MIS 7 isolated

951 C) Old shorelines

952

953 Table 1: Mean Upper Pleistocene Coastal Uplift rates of N Cotentin

954

955 Table 2: Hypothesis on middle Pleistocene apparent and eustasy-corrected uplift 956 rates of North Cotentin

957

958 Table 3: Hypothesis on the age of the upper rasas extrapolating various uplift rates 
960 Table 4: Result of the synchronous method modelling, elevations in red indicate that

961 younger sea-level high-stands would destroy the older high-stand shorelines or, in

962 some cases, suggest that shorelines and their terraces may be caused by more than

963 one sea-level high-stand.

964

965

References cited

966

967 Allard, M. and G. Tremblay (1981). "Observations sur le Quaternaire de l'extrémité

968 orientale de la péninsule de Gaspé, Québec." Géographie physique et

969 Quaternaire 35(1): 105-125.

970

971 Alonso, A. and J. L. Pagés (2000). "El registro sedimentario del final del cuaternario 972 en el litoral noroeste de la peninsula Iberica. Margenes Cantabrico y

973 Atlantico." Revista de la Sociedad Geologica de España 13(1): 17-29.

974

975 Alvarez-Marrón, J., R. Hetzel, S. Niedermann, R. Menéndez and J. Marquínez

976 (2008). "Origin, structure and exposure history of a wave-cut platform more

977 than $1 \mathrm{Ma}$ in age at the coast of northern Spain: A multiple cosmogenic 978 nuclide approach." Geomorphology 93(3-4): 316-334. 
980 Andersen, M. B., C. H. Stirling, E.-K. Potter, A. N. Halliday, S. G. Blake, M. T.

981

982

983

984

985

986

987

988

989

990

991

992

993

994

995

996

997 998 McCulloch, B. F. Ayling and M. O'Leary (2008). "High-precision U-series measurements of more than 500,000 year old fossil corals." Earth and Planetary Science Letters 265(1-2): 229-245.

Antoine, P., J.-P. Coutard, P. Gibbard, B. Hallegouet, J.-P. Lautridou and J.-C. Ozouf (2003). "The Pleistocene rivers of the English Channel region." Journal of Quaternary Science 18(3-4): 227-243.

Antoine, P., J. P. Lautridou, J. Sommé, P. Auguste, J. P. Auffret, S. Baize, M. CletPellerin, J.-P. Coutard, Y. Dewolf, O. Dugué, F. Joly, B. Laignel, M. Laurent, M. Lavollé, P. Munaut, P. Lebret, F. Lécolle, D. Lefebvre, N. LimondinLozouet, A.-V. Munaut, J.-C. Ozouf, F. Quesnel and D. Rousseau (1998). "Les formations quaternaires de la France du Nord-Ouest : Limites et corrélations [The quaternary formations of North-West France :." Quaternaire 9(3): 227241.

Arkell, W. J. (1943). "The Pleistocene rocks at trebetherick point, north Cornwall: their interpretation and correlation." Proceedings of the Geologist's Association 
1001 Auffret, J.-P., D. Alduc, C. Larsonneur and A. J. Smith (1980). "Cartographie du 1002 réseau des paléovallées et de l'épaisseur des formations superficielles 1003 meubles de la Manche orientale." Annales de l'Institut Océanographique, 1004 Paris 58(8): 21-35.

1005

1006 Authemayou, C., K. Pedoja, A. Heddar, S. Molliex, A. Boudiaf, B. Ghaleb, B. Vliet 1007 Lanoe, B. Delcaillau, H. Djellit, K. Yelles and M. Nexer (2017). "Coastal uplift 1008 1009 1010 west of Algiers (Algeria): pre- and post-Messinian sequences of marine terraces and rasas and their associated drainage pattern." International Journal of Earth Sciences: 1-23.

1011

1012 Baden-Powell, D. F. W. (1955). "The correlation of the Pliocene and Pleistocene 1013 marine beds of Britain and the Mediterranean." Proceedings of the Geologists' 1014 Association 66(part 4): 271-292.

1015

1016 Baize, S. (1998). Tectonique, eustatisme et climat dans un systeme 1017 geomorphologique cotier. Le nord-ouest de la france au plio-pleistocene : 1018 exemple du cotentin (normandie). Géologie. Caen, University of Caen: 333 p. 
1020 Balescu, S., S. C. Packman, A. G. Wintle and R. Grün (1992). "Thermoluminescence 1021 dating of the middle Pleistocene raised beach of Sangatte (Northern France)." Quaternary Research 37(3): 390-396.

1023

1024 Ballèvre, M., V. Bosse, C. Ducassou and P. Pitra (2009). "Palaeozoic history of the 1025 Armorican Massif: Models for the tectonic evolution of the suture zones." Comptes Rendus Geoscience 341(2-3): 174-201.

1028 Barrell, J. (1915). "Factors in movements of the strand line and theirs results in the 1029 Pleistocene and Post-Pleistocene." American Journal of Science Fourth 1030 Series $X L(235):$ 1-22.

1031

Bates, M. R., D. H. Keen and J. P. Lautridou (2003). "Pleistocene marine and 1033 periglacial deposits of the English Channel." Journal of Quaternary Science 18(3-4): 319-337.

1035 Battistini, R. and J. P. Bergoeing (1982). "Un exemple de côte à structure faillée quadrillée et néotectonique active : la côte pacifique du Costa Rica (The pacific coast of Costa Rica)." Bulletin de l'Association de géographes français 487-488: 199-205. 
1040 Baudet, J.-L. (1959). "Les industries des plages suspendues (de 5m) du Nord de la France." Bulletin et Mémoires de la Société d'anthropologie de Paris Xe série. Tome 10 (Fascicule 4): 285-301.

1043

1044 Bauer, H., P. Bessin, P. Saint-Marc, J.-J. Châteauneuf, C. Bourdillon, R. Wyns and F. 1045 o. Guillocheau (2016). "The Cenozoic history of the Armorican Massif: New 1046 1047 insights from the deep CDB1 borehole (Rennes Basin, France)." $\underline{\text { Comptes }}$ Rendus Geoscience 348(5): 387-397.

1048

1049 Benabdellouahed, M., O. Dugué, B. Tessier, I. Thinon and P. Guennoc (2013). 1050 "Evolution pléistocène de la Seine fluviatile préservée en Baie de Seine." Bulletin de l'Association Française pour l'Etude du Quaternaire 24(3): 267-277.

1052

1053 Benedetti, M. M., J. A. Haws, C. L. Funk, J. M. Daniels, P. A. Hesp, N. F. Bicho, T. A. 1054 Minckley, B. B. Ellwood and S. L. Forman (2009). "Late Pleistocene raised 1055 beaches of coastal Estremadura, central Portugal." Quaternary Science $1056 \quad$ Reviews 28(27-28): 3428-3447. 
1058 Bertotti, G. and M. Gouiza (2012). "Post-rift vertical movements and horizontal

1059

1060

1061

1062

1063

1064

1065

1066

1067

1068

1069

1070

1071

1072

1073

1074

1075

Bigot, A. (1930). "Les terrasses pléistocènes du littoral du Cotentin." Livre Jubilaire de la Société Géologique de France tl: 133-148. deformations in the eastern margin of the Central Atlantic: Middle Jurassic to Early Cretaceous evolution of Morocco." International Journal of Earth Sciences 101(8): 2151-2165.

Bessin, P., F. Guillocheau, C. Robin, J.-M. Schroëtter and H. Bauer (2015). "Planation surfaces of the Armorican Massif (western France):Denudation chronology of a Mesozoic land surface twice exhumed in response to relative crustal movements between Iberia and Eurasia." Geomorphology 233: 75-91.

Bigot, A. (1897). "Sur les dépôts pléistocènes et actuels du littoral de la BasseNormandie." Comptes Rendus de l'Académie des Sciences, Paris 115: 380.

Bigot, A. (1898). "Feuille des Pieux." Bulletin de la Carte Géologique 63(Tome X): 17.

\section{de la Sociéte Géologique de France tl: 133-148.}


1077 Bigot, A. (1931). Les terrasses littorales du Cotentin. Congrès International de 1078 Géographie, Paris Librairie Armand Colin.

1079

1080 Bintanja, R. and R. S. W. Van de Wal (2008). "North American ice-sheet dynamics 1081 and the onset of 100,000-year glacial cycles." Nature 454(7206): 869-872.

1082

1083 Bonnet, S., F. Guillocheau, J.-P. Brun and J. Van Den Driessche (2000). "Large 1084 scale relief development related to Quaternary tectonic uplift of a Proterozoic1085 1086 Paleozoic basement: The Armorican Massif, NW France." Journal of Geophysical Research: Solid Earth 105(B8): 19273-19288.

1087

1088 Bonow, J. M., P. Japsen, P. F. Green, P. R. Cobbold, A. J. Pedreira, R. Lilletveit and 1089 D. Chiossi (2009). "Post-rift landscape development of north-east Brazil." 1090 Geological Survey of Denmark and Greenland Bulletin 17: 81-84.

1092 Bowles, C. J. and E. Cowgill (2012). "Discovering marine terraces using airborne 1093 LiDAR along the Mendocino-Sonoma coast, northern California." Geosphere 1094 8(2): 386-402. 
1096 Bradley, W. C. (1957). "Origin of marine terrace deposits in the Santa Cruz area, 1097 California." Bulletin of the Geological Society of America 68: 421-444.

1098

1099 Bradley, W. C. and G. B. Griggs (1976). "Form, genesis, and deformation of central 1100 California wave-cut platforms." Geological Society of America bulletin 87(3): 433-449.

1103 Brault, N., S. Bourquin, F. Guillocheau, M. P. Dabard, S. Bonnet, P. Courville, J. 1104 Esteoule-Choux and F. Stepanoff (2004). "Mio-Pliocene to Pleistocene paleotopographic evolution of Brittany (France) from a sequence stratigraphic analysis: relative influence of tectonics and climate." Sedimentary Geology 163(3): 175-210.

1108

1109 Breton, G., R. Cousin, M.-F. Huault, C. Lechevallier and D. Lefebvre (1991). "Les sédiments quaternaires du quartier de l'Hôtel de Ville, au Havre : séquences marines pré-éemienne, éemienne et holocène de l'estuaire de la Seine." Bulletin trimestrielle de la Société géologique de Normandie et amis du Muséum du Havre 78(4): 15-63.

1115 Breuil, H., M. Vaultier and G. Zbyszewski (1942). "Les Plages anciennes portugaises 
1119 Bridgland, D. R. (2002). "Fluvial deposition on periodically emergent shelves in the 1120

1123 Brodie, J. and N. White (1994). "Sedimentary basin inversion caused by igneous 1124 1125

entre les Caps d'Espichel et Carvoeiro et leurs industries paléolithiques." Bulletin de la Société Préhistorique de France Tome 39(3-4): 93-98.

Quaternary: example records from the shelf around Britain." Quaternary International 92(1): 25-34. underplating: Northwest European continental shelf." Geology 22(2): 147-150.

Bull, A. J. (1941). "Pleistocene chronology." Proceedings of the Geologists' Association LIII(part I ): 1-44.

Burrough, P. A. and R. A. McDonnell (1998). "Creating continuous surfaces from point data." Principles of Geographic Information Systems. Oxford University Press, Oxford, UK.

Butaeye, D., E. Laville and J. Le Gall (2001). "Géomètrie et ciématique des chevauchements varisques du Nord-Est du Massif armoricain (France)." 

Planetary Science 332(4): 283-289.

1138 Campar de Almeida, A. (2001). "A carsificacao da serra da Boa Viagem: um processo Quaternario." Estudos do Quaternario Revista da Associaçao Portuguesa para o Estudo do Quaternario 4: 29-33.

1141 Caputo, R. (2007). "Sea-level curves: Perplexities of an end-user in morphotectonic applications." Global and Planetary Change 57(3-4): 417-423.

1144 Chambers, R. (1848). Ancient Sea-margins, as memorial of changes in the relative level of sea and land. Edinburgh, W \& R Chambers.

1147 Clet-Pellerin, M., S. Baize, A.-V. Walter, O. Dugué and J.-P. Coutard (1997). "Mise 1148 en évidence d'un interglaciaire du Pléistocène inférieur dans une formation fluviatile du Seuil du Cotentin (Normandie, France)." Géographie Physique et $1150 \quad$ Quaternaire 51(3): 363-378.

1152 Cliquet, D. (2015). Les occupations néandertaliennes : des sites spécialisés (250 000 1153 à 40000 ans) Dans les pas de Néandertal : Les premiers hommes en 

and J.-M. Levesque. Caen, Faton Edition: 84-91.

1157 Cliquet, D. and J. P. Lautridou (2009). "Les occupations humaines du Pléistocène 1158 moyen de Normandie dans leur cadre environnemental." Quaternaire 20(3):

1159 305-320.

1161 Cliquet, D., J. P. Lautridou, M. Lamothe, N. Mercier, J.-L. Schwenninger, P. Alix and G. Vilgrain (2009). "Nouvelles données sur le site majeur d'Ecalgrain: Datations radiométriques et occupations humaines de la pointe de la Hague (Cotentin, Normandie)." Quaternaire 20(3): 345-359.

1166 Cliquet, D., N. Mercier, H. Valladas, L. Froget, D. Michel, B. Van Vliet-Lanoë and G. Vilgrain (2003). "Apport de la thermoluminescence sur silex chauffés à la chronologie de sites paléolithiques de Normandie : nouvelles données et interprétations " Quaternaire 14(1): 51-64.

1171 Coutard, J.-P. and J. P. Lautridou (1975). "Le Quaternaire de Grandcamp 1172 (Calvados), Loess et plages marines normanniennes: un problème de 1173 datation." Bulletin de la Société Linnéenne de Normandie 104(136-144). 
1175 Coutard, J.-P., J. P. Lautridou, D. Lefebvre and M. Clet (1979). "Les bas-niveaux marins éemien et pré-éemien de Grandcamp - les - bains." Bulletin de la Société Linneénne de Normandie 107: 11-20.

1178

1179 Coutard, S. (2003). Formations quaternaires en bordure d'une mer épicontinentale, la Manche : tectonique, eustatisme, climat et occupations humaines. Exemple du Val de Saire (Normandie, France). Caen, Université de Caen: 445.

1183 Coutard, S., J. P. Lautridou and E. Rhodes (2005). "Discontinuités dans l'enregistrement des cycles glaciaires interglaciaires sur un littoral en contexte intraplaque, exemple du Val de Saire (Normandie, France) " Quaternaire 16(3): 217-227.

1188 Coutard, S., J.-P. Lautridou, E. Rhodes and M. Clet (2006). "Tectonic, eustatic and climatic significance of raised beaches of Val de Saire, Cotentin, Normandy, France." Quaternary Science Reviews 25(5-6): 595-611.

1192 Cunha, L. S., A. A. Martins, J. Cabral, M. P. Gouveia, J.-P. Buylaert and A. S. Murray 
1202

1203

1204

1205

1206 1207 1208 1209 1210 (2015). Staircases of wave-cut platforms in western central Portugal (Cape Mondego to Cape Espichel) - relevance as indicators of crustal uplift. VIII Simposio sobre el Margen Iberico Atlantico, Malaga Centro Oceanografico de Malaga.

Cunha, P. P., A. A. Martins, J. Cabral, M. P. Gouveia, J.-P. Buylaert and A. S. Murray (2015). Escadrias de terracos marinhos em Portugal centro-ocidental relevância como indicadores de soerguimento crustal. VOO Congresso Nacional de Geomorfologia Lisboa

Daly, R. A. (1925). "Pleistocene changes of level." American Journal of Science - fifth serie $X(58): 281-313$

Davies, B. J., D. R. Bridgland, D. H. Roberts, C. O. Cofaigh, S. M. Pawley, I. Candy, B. Demarchi, K. E. H. Penkman and W. E. N. Austin (2009). "The age and stratigraphic context of the Easington Raised Beach, County Durham, UK." Proceedings of the Geologists' Association 120(4): 183-198.

Dawson, A. G., S. Dawson, A. G. Cooper, A. Gemmell and R. Bates (2013). "A Pliocene age and origin for the strandflat of the Western Isles of Scotland: a 
1215 Depéret, C. (1918-1922). "Essai de coordination chronologique générale des temps 1216 quaternaires : les formations marines " Extraits des Comptes rendus des $\begin{array}{llll}\text { séances l'Académie de des } & \text { Sciences }\end{array}$ $166,480,636,884,167,418,979,168,868,873,170,159,171,212,174,1502,1594$.

1220 Dèzes, P., S. M. Schmid and P. A. Ziegler (2004). "Evolution of the European Cenozoic Rift System: interaction of the Alpine and Pyrenean orogens with their foreland lithosphere." Tectonophysics 389(1): 1-33.

1224 Døssing, A., P. Japsen, A. B. Watts, T. Nielsen, W. Jokat, H. Thybo and T. Dahlae• Jensen (2016). "Miocene uplift of the NE Greenland margin linked to plate tectonics: Seismic evidence from the Greenland Fracture Zone, NE Atlantic." Tectonics 35 (2) : 257-282

1229 Dugué, O. (2003). "The Pliocene to Early Pleistocene marine to fluviatile succession 1230 of the Seuil du Cotentin basins (Armorican Massif, Normandy, France)." Journal of Quaternary Science 18(3-4): 215-226. 
1233 Dugué, O., J.-P. Auffret and N. Poupinet (2007). "Cenozoic shelly sands in the Cotentin (Armorican Massif, Normandy, France): A record of Atlantic transgressions and intraplate Cenozoic deformations." Comptes Rendus 1236 Geoscience 339(2): 110-120.

1238 Dugué, O., J. P. Lautridou, F. Quesnel, M. Clet, N. Poupinet and C. Bourdillon 1239 (2009). "Évolution sédimentaire cénozoïque (Paléocène à Pléistocène inférieur) de la Normandie." Quaternaire 20(3): 275-303.

1242 Dunlop, A. (1893). "On Raised Beaches and Rolled Stones at High Levels in Jersey." Quarterly Journal of the Geological Society 49(1-4): 523-530.

1245 Dupret, L., E. Dissler, F. Doré, F. Gresselin and J. Le Gall (1990). "Cadomian 1246 geodynamic evolution of the northeastern Armorican Massif (Normandy and Maine)." Geological Society, London, Special Publications 51(1): 115-131.

1249 Dutton, A., E. Bard, F. Antonioli, T. M. Esat, K. Lambeck and M. T. McCulloch (2009). 1250 "Phasing and amplitude of sea-level and climate change during the 
penultimate interglacial." Nature Geosciences 2(5): 355-359.

1252

1253 Elhaï, H. (1960). "A propos des niveaux marins quaternaires en Normandie." Bulletin 1254 de la Société Linnéenne de Normandie 1: 137-145.

1255

1256 Ferreira Soares, A. (1999). "As unidades Pliocenicas e Quaternarias no espaço do 1257 baixo Mondego (uma perspectiva de ordem)." Estudos do Quaternario Revista 1258 da Associaçao Portuguesa para o Estudo do Quaternario 2: 7-17.

1260 Ferreira Soares, A., P. M. Callapez and J. Fonseca Marques (2007). "The Farol 1261 deposit (deposito do Farol) - a pleistocene beach deposit from Cape Mondego (Figueira da Foz, West Central Portugal)." Ciencas da Terra (UNL) 16: 1631263 173.

1264

1265 Figueiredo, P. M., J. Cabral and T. K. Rockwell (2011). Plio-Pleistocene tectonic 1266 activity in the Southwest of Portugal. 2nd INQUA - IGCP 567 International 1267 workshop on Active Tectonics, Earthquake Geology, Archealogy and 1268 engineering, Corinth, Greece. 
1270 Fleury, L., J.-P. Clément, F. o. Ménillet, G. Moguedet, C. Vinchon and G. Farjanel (1989). "Les sables rouges et graviers des plateaux et des karsts du Maine méridional; Etude sédimentologique." Géologie de la France 1(2): 255-257.

1273

1274 Font, M., J.-L. Lagarde, D. Amorese, J.-P. Coutard and J.-C. Ozouf (2002). "Une 1275 méthode de quantification de la dégradation d'un escarpement de faille au 1276 1277 cours des cycles climatiques du Quaternaire : la faille de Jobourg (Nord Cotentin, France)." Comptes Rendus Geoscience 334(3): 171-178.

1278

1279 Frankel, K. L. and J. F. Dolan (2007). "Characterizing arid region alluvial fan surface 1280 roughness with airborne laser swath mapping digital topographic data." 1281 Journal of Geophysical Research: Earth Surface 112(F2).

1282

1283 Garcin, M., G. Farjanel, S. Courbouleix, P. Barrier, P. Braccini, G. Brébion, R. P. 1284 1285 1286 Carbonel, J. C. Carriol and M. Clet-Pellerin (1997). "La longue séquence Pliocène de Marchésieux -résultats analytiques et premiers résultats " Géologie de la France 3: 39-77.

1288 Gautier, M. (1967). "La tectonique tertiaire dans le massif Armoricain." Annales de $1289 \quad$ Géographie 414: 168-197. 
1291 Gibbard, P.L. (1988). "The history of the great northwest European rivers during the 1292 past three million years". Philosophical Transactions of the Royal Society of London, Series B 318: 559-602

1294

1295 Gonzalez-Acebron, L., R. Mas, J. Arribas, J. M. Gutierrez-Mas and C. Perez-Garrido 1296 (2016). "Very coarse-grained beaches as a response to generalized sea level drops in a complex active tectonic setting: Pleistocene marine terraces at the Cadiz coast, SW Spain." Marine Geology 382(Supplement C): 92-110.

Graindor, M. J. (1964). "Le Quaternaire marin de Normandie." Bulletin de la Société Géologique de Normandie et des Amis du Muséum du Havre 54: 1-15.

1302

1303 Grant, K. M., E. J. Rohling, C. B. Ramsey, H. Cheng, R. L. Edwards, F. Florindo, D. 1304 Heslop, F. Marra, A. P. Roberts and M. E. Tamisiea (2014). "Sea-level 1305

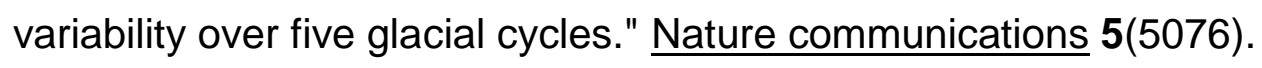

1307 Green, P. F., I. R. Duddy, P. Japsen, J. M. Bonow and J. A. Malan (2016). "Post1308 breakup burial and exhumation of the southern margin of Africa." Basin 
1311 Gresselin, F. (2000). Evolution varisque du Massif armoricain oriental : insertion dans 1312

1313 une transversale ouest-européenne. Ecole de Géologie Structurale Caen, University of Caen: $335 \mathrm{p}$.

1314

1315 Guilcher, A. (1949). "Aspects et problèmes morphologiques du massif de Devon1316 Cornwall comparés à ceux d'Armorique." Revue de Géographie Alpine 37(4): 689-717.

1318

1319 Guilcher, A. (1951). "La formation de la mer du Nord, du Pas-de-Calais et des 1320 plaines maritimes environnantes." Revue de géographie de Lyon 26(3): 3111321 329.

1322

1323 Guilcher, A. (1969). "Pleistocene and Holocene sea level changes " Earth Sciences 1324 Review 5: 69-97.

1326 Guilcher, A. (1974). "Les «rasas» : un problème de morphologie littorale générale." 1327 Annales de Géographie 83(455): 1-33. 
1329 Guilcher, A. and B. Hallegouet (1981). "Le haut cordon de galets Pléistocène de 1330 Ruvein en Plovan (Finistère) et ses enseignements généraux." Bulletin de 1331 l'Association Française pour l'Etude du Quaternaire 18(6): 75-82.

1332

1333 Guillocheau, F., N. Brault, E. Thomas, J. Barbarand, S. Bonnet, S. Bourquin, J. 1334 Estéoule-Choux, P. Guennoc, D. Menier, D. Néraudeau, J.-N. Proust and R. 1335 1336 1337 Wyns (2003). "Histoire géologique du Massif Armoricain depuis $140 \mathrm{Ma}$ (Crétacé-Actuel)." Bulletin Information Géologique du Bassin de Paris 40(1): $13-28$.

1338

1339

Hallégouët, B. (1976). "Les anciens dépôts marins et fluviatiles de la vallée de l'Elorn 1340 (Finistère) " Norois 89: 55-72.

1341

1342 Hamblin, R.J.O. Crosby, A. Balson, P.S. Jones, S.M. Chadwick, R.A., Penn I.E., 1343 Arthur M.J. (1992). The Geology of the English Channel. United Kingdom 1344 Offshore Regional Report, British Geological Survey. HMSO: London; 106 pp

1346 Home, H. (1912). "Worked flints obtained from the 25 -foot raised beach near 
Holywood, co. Down." Nature 2248(90): 361.

1348

1349 Husson, L., P. Yamato and A. Bézos (2015). "Ultraslow, slow, or fast spreading 1350 ridges: Arm wrestling between mantle convection and far-field tectonics." Earth and Planetary Science Letters 429: 205-215.

1352

1353 Japsen, P., J. Bonow, P. Green, J. Chalmers and K. Lidmar- Bergström (2006). 1354 "Elevated, passive continental margins: Long-term highs or Neogene uplifts? New evidence from West Greenland." Earth and Planetary Science Letters 248: $330-339$.

1358 Japsen, P., J. M. Bonow, P. F. Green, P. R. Cobbold, D. Chiossi, R. Lilletveit, L. P. 1359 Magnavita and A. Pedreira (2012). "Episodic burial and exhumation in NE $1360 \quad$ Brazil after opening of the South Atlantic." Geological Society of America $1361 \quad$ Bulletin 124(5-6): 800-816.

1363 Japsen, P. and J. A. Chalmers (2000). "Neogene uplift and tectonics around the $1364 \quad$ North Atlantic: overview." Global and Planetary Change 24(3): 165-173. 
1366 Jara-Muñoz, J. and D. Melnick (2015). "Unraveling sea-level variations and tectonic uplift in wave-built marine terraces, Santa Maria Island, Chile." Quaternary Research 83(1): 216-228.

1369

Jara-Muñoz, J., D. Melnick and M. R. Strecker (2016). "TerraceM: A MATLAB® tool to analyze marine and lacustrine terraces using high-resolution topography." Geosphere 12(1): 176-195.

1373

1374 Jara-Muñoz J, Melnick D, Zambrano P, Rietbrock A, Gonzáles J, Argandoña B, 1375 Strecker MR. (2017): "Quantifying offshore forearc deformation and splay-fault slip using drowned Pleistocene shorelines, Arauco Bay, Chile". Journal of Geophysical Research, Solid Earth, 122 (6) 4529-4558.

1378

1379 Jardine, W. G. (1981). "The determination of former shoreline positions in areas of 1380 large tidal range, with examples taken mainly from Scotland." Bulletin de l'Association française pour l'étude du quaternaire 18(2): 67-70.

1383 Juignet, P. (1980). "Transgressions-régressions, variations eustatiques et influences tectoniques de l'Aptien au Maastrichtien dans le Bassin de Paris occidental et sur la bordure du Massif armoricain." Cretaceous Research 1(4): 341-357. 
1387 Klein (1975). "Massif armoricain et Bassin parisien." Fondation Baulig Vol 2

1389 Kopp, R. E., F. J. Simons, J. X. Mitrovica, A. C. Maloof and M. Oppenheimer (2009). "Probabilistic assessment of sea level during the last interglacial stage." Nature 462(7275): 863-867.

1392

1393 Lagarde, J. L., D. Amorese, M. Font, E. Laville and O. Dugué (2003). "The structural 1394 evolution of the English Channel area." Journal of Quaternary Science 18(31395 4): 201-213.

1396

1397 Lagarde, J.-L., S. Baize, D. Amorese, B. Delcaillau, M. Font and P. Volant (2000). 1398 "Active tectonics, seismicity and geomorphology with special reference to 1399 Normandy (France)." Journal of Quaternary Science 15(7): 745-758.

1401 Lajoie, K. R. (1986). Coastal Tectonics. Active tectonic. N. A. Press. Washington 1402 D,C, National Academic Press: 95-124. 
1404 Lajoie, K. R., D. J. Ponti, C. L. Powell, A. M. Mathieson and A. M. Sarna - Wojcicki 1405 (1991). Emergent marine strandlines and associated sediments, coastal California: a record of Quaternary sea-level fluctuations, vertical tectonic movements, climatic changes, and coastal processes. Quaternary Nonglacial Geology: Conterminous U.S.: The Geology of North America. Morrison. Boulder, Colorado, Geological Society of America. K-2: 190-214.

1411 Lambeck, K. (1991). "Glacial rebound and sea-level change in the British Isles." $1412 \quad$ Terra Nova 3(4): 379-389.

1414 Lambeck, K. (1996). "Glaciation and sea-level change for Ireland and the Irish Sea 1415 since Late Devensian/Midlandian time." Journal of the Geological Society 1416 153(6): 853-872.

1418 Larsonneur, C., R. Horn, J. P. Auffret, P. Hommeril and A. Moal (1975). "Geologie de 1419 la Partie Meridionale de la Manche Centrale." Philosophical Transactions of the Royal Society of London A: Mathematical, Physical and Engineering Sciences 279(1288): 145-153.

1422

1423 Lautridou, J. P. (1983). Le Quaternaire de Normandie. Caen, Centre de 
1426 Lautridou, J. P. (1985). Le cycle périgaciaire pléistocène en Europe du Nord-Ouest et plus particulièrement en Normandie. Centre de Géomorphologie du CNRS. Caen, University of Caen. Doctorat d'état: 970.

1430 Lautridou, J. P. (1989). "Les lignes de rivages Pléistocènes en Normandie âge des plates-formes littorales." Bulletin du Centre de Géomorphologie du CNRS, Caen 36: 231-234.

1434 Lautridou, J. P., S. Baize, M. Clet, J.-P. Coutard and J.-C. Ozouf (1999). "Les 1435 séquences plio-pléistocènes littorales et estuariennes de Normandie." Quaternaire 10(2-3): 161-169.

1437

1438 Leorri, E., F. Fatela, T. Drago, S. L. Bradley, J. Moreno and A. Cearreta (2012). 1439 "Lateglacial and holocene coastal evolution of the Minho estuary (N Portugal) : 1440 implications for understanding sea-level changes in Atlantic Iberia." The $1441 \quad$ Holocene 23(3): 353-363. 
1443 Lericolais, G., J.-P. Auffret and J.-F. Bourillet (2003). "The Quaternary Channel River:

1444 seismic stratigraphy of its palaeo-valleys and deeps." Journal of Quaternary $1445 \quad$ Science 18(3-4): 245-260.

1446

1447 Lisiecki, L. E. and M. E. Raymo (2005). "A Pliocene-Pleistocene stack of 57 globally 1448 distributed benthic delta $18 \mathrm{O}$ records." Paleoceanography 20: PA1003.

1450 Lyell, C. (1830). Principles of geology, being an attempt to explain the former 1451 1452 changes of the earth's surface, by reference to causes now in operation. London, John Murray.

1453

1454 Mellett, C. L., D. M. Hodgson, A. J. Plater, B. Mauz, I. Selby and A. Lang (2013). 1455 "Denudation of the continental shelf between Britain and France at the 1456 glacialâ€“interglacial timescale." Geomorphology 203: 79-96.

1458 Melnick, D. (2016). "Rise of the central Andean coast by earthquakes straddling the 1459 Moho." Nature Geoscience.9: 401-416.

1461 Miller, K. G., M. A. Kominz, J. V. Browning, J. D. Wright, G. S. Mountain, M. E. Katz, 
1462

1463

1464

1465

1466

1467

1468

1469

1470 Moore, D. (1842). "On fossil bones found on the surface of a raised beach at the 1471

1472

1473

1474 1475

1476

1477 Murray-Wallace, C. and C. Woodroffe (2014). Quaternary sea level : a global 1478 perspective. Cambridge, Cambridge University Press.

1479

1480 Nexer, M. (2015). Etudes conjointe des réseaux de drainage et des paléocôtes plio- 
quaternaires soulevées:exemples de I'Indonésie et du Golfe Normand Breton. Caen, University of Caen. PhD: 374 pp

1483

1484

1485

1486

Oliva (1977). "La plateforme Moghrébienne : néotectonique et eustatisme sur le littoral de l'Anti-Atlas." Méditerranée Deuxième série, Tome 29(2): 73-91.

Pareyn, C. (1980). "Mise en évidence d'une activité néotectonique pliocène et quaternaire dans le Cotentin, le bassin de Carentan et le Bessin (Manche et Calvados)." Bulletin de la Société Géologique de France tome XXII(4): 695701.

Paskoff, R. and P. Sanlaville (1983). "Les côtes de la Tunisie, variations du niveau marin depuis le tyrrhénien. Travail réalisé dans le cadre de l'ERA 345 du CNRS " Collection de la Maison de l'Orient Méditerranéen : Série Géographique et Préhistorique: 190.

Pedoja, K., J. F. Dumont, M. Lamothe, L. Ortlieb, J.-Y. Collot, B. Ghaleb, M. Auclair, V. Alvarez and B. Labrousse (2006) a. "Plio-Quaternary uplift of the Manta Peninsula and La Plata Island and the subduction of the Carnegie Ridge, central coast of Ecuador." Journal of South American Earth Sciences 22(1-2): $1-21$. 
1501 Pedoja, K., L. Ortlieb, J. F. Dumont, M. Lamothe, B. Ghaleb, M. Auclair and B.

1502

1503

1504

1505

1506

1507

1508

1509

1510

1511

1512

1513

1514

1515

1516

1517 Pellerin, J., P. Brebion, M. Helluin, J.-T. Hollin, A. Lauriat - Rage, D. Lefévre and G. 1518

1519

1520 Labrousse (2006) b. "Quaternary coastal uplift along the Talara Arc (Ecuador, Northern Peru) from new marine terrace data." Marine Geology 228(1-4): 7391.

Pedoja, K., L. Husson, V. Regard, P. R. Cobbold, E. Ostanciaux, M. E. Johnson, S. Kershaw, M. Saillard, J. Martinod, L. Furgerot, P. Weill and B. Delcaillau (2011). "Relative sea-level fall since the last interglacial stage: Are coasts uplifting worldwide?" Earth-Science Reviews 108(1-2): 1-15.

Pedoja, K., L. Husson, M. E. Johnson, D. Melnick, C. Witt, S. Pochat, M. Nexer, B. Delcaillau, T. Pinegina, Y. Poprawski, C. Authemayou, M. Elliot, V. Regard and F. Garestier (2014). "Coastal staircase sequences reflecting sea-level oscillations and tectonic uplift during the Quaternary and Neogene." EarthScience Reviews 132(0): 13-38.

H. Miller (1987). "Données nouvelles sur le gisement marin Quaternaire + 14.5/15.7 m NGF du cimetière de Luc sur mer (Calvados, France)." Bulletin du Centre de Géomorphologie du CNRS, Caen 32(99-115). 
1522 Pellerin, J. and P. A. Dupeuble (1979). "Le bas niveau marin Eemien de Graye-sur1523 Mer (Calvados)." Bulletin Société Linnéene de Normandie 107: 21-26.

1524

1525 Peulvast, J.-P., V. C. Sales, F. O. Bâtard and Y. Gunnell (2008). "Low post1526 Cenomanian denudation depths across the Brazilian Northeast: implications for long-term landscape evolution at a transform continental margin." Global and Planetary Change 62(1): 39-60.

1530 Prestwich, J. (1851). "On the Drift at Sangatte Cliff, near Calais." Quarterly Journal of 1531 the Geological Society 7(1-2): 274-278.

1533 Prestwich, J. (1862-1863). "Theoretical considerations on the condition under which 1534 the drift deposits containing the remains of extinct mammalia and flintimplements were accumulated : and on their geological age." Proceedings of the Royal Society of London 12: 38-52.

1538 Prestwich, J. (1865). "Additional Observations on the Raised Beach of Sangatte with reference to the Date of the English Channel, and the Presence of Loess in 
the Cliff Section." Quarterly Journal of the Geological Society 21(1-2): 440442.

1542

1543 Prestwich, J. (1892). "The Raised Beaches, and 'Head' or Rubble-drift, of the South 1544 of England: their Relation to the Valley Drifts and to the Glacial Period; and on 1545 1546 a late post-Glacial Submergence." Quarterly Journal of the Geological Society 48(1-4): 263-343.

1548 Quezada, J., G. Gonzalez, T. Dunai, A. Jensen and J. Juez-Larré (2007). 1549 "Alzamiento litoral Pleistoceno del norte de Chile: edades $21 \mathrm{Ne}$ de la terraza 1550 costera más alta del área deCaldera-Bahía Inglesa." Revista Geológica de 1551 Chile 34(1): 81-96.

1552

1553 Ramos, A. M. and P. P. Cunha (2009). O Pliocenico e o Plistocenico da plataforma 1554 litoral entre os paralelos da Serra da Boa Viagem e da Nazaré (Portugal central). 6 e simposio sobre a margem iberico atlantica, Oviedo.

1557 Ramos, A. M., P. P. Cunha, L. S. Cunha, A. Gomes, F. C. Lopes, J.-P. Buylaert and 1558 A. S. Murray (2012). "The River Mondego terraces at the Figueira da Foz 1559 coastal area (western central Portugal): geomorphological and 
1574 Regard, V., M. Saillard, J. Martinod, L. Audin, S. Carretier, K. Pedoja, R. Riquelme, 1575

sedimentological characterization of a terrace staircase affected by differential uplift and glacio eustasy " Geomorphology 165-166: 107-123.

Ramos, A. M., P. P. Cunha, A. Gomes and L. S. Cunha (2010). Caracterizaçao geomorfologica e sedimentologica da escadaria de terraços da margem direita do rio Mondego, no sector entre Maiorca e Vila Verde. VI Seminario Latino Americano de Geografia Fisica II Seminario Ibero Americano de Geografia Fisica Coimbra, Universidad de Coimbra.

Raynal, J.-P., D. Lefevre, D. Geraads and M. El Graoui (1999). "Contribution du site paléontologique de Lissasfa (Casablanca, Maroc) à une nouvelle interprétation du Mio-Pliocène de la Méseta." Comptes Rendus de l'Académie des Sciences-Series IIA-Earth and Planetary Science 329(8): 617-622. P. Paredes and G. Hérail (2010). "Renewed uplift of the Central Andes Forearc revealed by coastal evolution during the Quaternary." Earth and Planetary Science Letters 297(1-2): 199-210.

Regnauld, H., B. Mauz and M.-T. Morzadec-Kerfourn (2003). "The last interglacial 

77.

1582

1583

1584

1585

1586

1587

1588

1589

1590

1591

1592

1593

1594

1595

1596

1597

1598

Renouf, J. and L. James (2011). "High level shore features of Jersey (Channel Islands) and adjacent areas." Quaternary International 231(1-2): 62-77.

Roberts, G. P., M. Meschis, S. Houghton, C. Underwood and R. M. Briant (2013). "The implications of revised Quaternary palaeoshoreline chronologies for the rates of active extension and uplift in the upper plate of subduction zones." Quaternary Science Reviews 78: 169-187.

Rohling, E. J., G. L. Foster, K. M. Grant, G. Marino, A. P. Roberts, M. E. Tamisiea and F. Williams (2014). "Sea-level and deep-sea-temperature variability over the past 5.3 million years." Nature 508(7497): 477-482.

Rohling, E. J., K. Grant, M. Bolshaw, A. P. Roberts, M. Siddall, C. Hemleben and M. Kucera (2009). "Antarctic temperature and global sea level closely coupled over the past five glacial cycles." Nature Geosciences 2: 500-504. 
1599 Rosenbaum, G., G. S. Lister and C. Duboz (2002). "Relative motions of Africa, Iberia 1600 and Europe during Alpine orogeny." Tectonophysics 359(1-2): 117-129.

1601

1602 Sanlaville, P. (1974). "Le rôle de la mer dans les aplanissements côtiers du Liban." $1603 \quad$ Revue de géographie de Lyon 49(4): 295-310.

1604

1605 Scuvée, F. and D. Alduc (1981). "Deux niveaux marins Pléistocènes et leurs 1606 1607 industries paléolithiques respectives sur le littoral du Cotentin (Manche)." Bulletin de la Société préhistorique française tome 78: 210-218.

1608

1609 Shakun, J. D., D. W. Lea, L. E. Lisiecki and M. E. Raymo (2015). "An 800-kyr record 1610 of global surface ocean $\hat{I}^{\prime} 180$ and implications for ice volume-temperature 1611 coupling." Earth and Planetary Science Letters 426: 58-68.

1612

1613 Shennan, I. and B. Horton (2002). "Holocene land- and sea-• level changes in Great 1614 Britain." Journal of Quaternary science 17(5-6): 511-526.

1615

1616 Sheppard, G. (1927). "Geological observations on Isla de la Plata, Ecuador, South 1617 America." American Journal of Science 13: 480-486. 
1619 Sheppard, G. (1930). "The geology of southwestern Ecuador." American Association of Petroleum Geologist Bulletin 14: 263-309.

1621

1622 Siddall, M., J. Chappell and E.-K. Potter (2006). Eustatic sea level during past 1623 interglacials. The Climate of Past Interglacials. F. Sirocko, M. Claussen, M. F. Sanchez Goñi and T. Litt. Amsterdam, Elsevier: 75-92.

1626 Siddall, M., E. J. Rohling, A. Almogi-Labin, C. Hemleben, D. Meischner, I. Schmelzer and D. A. Smeed (2003). "Sea-level fluctuations during the last glacial cycle." Nature 423(6942): 853-858.

1629

1630 Silva, C., B. Landau, R. Domènech and J. Martinelli (2010). "Pliocene Atlantic 1631 molluscan assemblages from the Mondego Basin (Portugal):age and 1632 palaeoceanographic implications." Palaeogeography, Palaeoclimatology, Palaeoecology 285: 248-254.

1635 Sommé, J. and P. Antoine (1989). "La plaine maritime de la mer du Nord (France) et 1636 le pas de Calais : du Pléistocène moyen à l'Holocène." Bulletin du Centre de 
1639 Sommé, J., P. Antoine, N. Cunat-Bogé, D. Lefèvre and A. V. Munaut (1999). "The 1640 marine middle pleistocene of the north sea in France : Sangatte cliff and Herzeele formation." Quaternaire 10(2-3): 151-160.

1642

1643 Spratt, R. M. and L. E. Lisiecki (2016). "A Late Pleistocene sea level stack." Climate 1644 of the Past 12(4): 1079.

1645

1646 Stirling, C. H., T. M. Esat, K. Lambeck and M. T. McCulloch (1998). "Timing and 1647 duration of the Last Interglacial: evidence for a restricted interval of $1648 \quad$ widespread coral reef growth." Earth and Planetary Science Letters 160(3-4): $1649 \quad 745-762$.

1650

1651 Stirling, C. H., T. M. Esat, K. Lambeck, M. T. McCulloch, S. G. Blake, D.-C. Lee and 1652 A. N. Halliday (2001). "Orbital Forcing of the Marine Isotope Stage 9 1653 Interglacial." Science 291(5502): 290-293.

1655 Sutcliffe, A. J., A. P. Currant and C. B. Stringer (1987). "Evidence of sea-level 
change from coastal caves with raised beach deposits, terrestrial faunas and dated stalagmites." Progress in oceanography 18(1-4): 243-271.

1658

1659 Szabo, B. J. and J. G. Vedder (1971). "Uranium-series dating of some pleistocene 1660 marine deposits in southern California." Earth and Planetary Science Letters 1661 11: $283-290$.

1662

1663 Teixeira, C. (1944). "Tectonica Plio-Pleistonica do Noroeste Peninsular." Boletim da 1664 Sociedade Geológica de Portugal Vol. IV(Fasc. I-II): 19-40.

1665

1666 Teixeira, C. (1948). "Les dépôts modernes du littoral portugais au Nord de Leiria." 1667 Boletim da Sociedade Geológica de Portugal Vol. VII(Fasc. I-II): 83-94.

1668

1669 Telfer, M., J. L. Schwenninger, R. T. Walker, R. A. Sloan, A. B. Watts, R. L. Kahle, B. 1670 Kahle and M. W. Dee (2016). "Rapid mantle-driven uplift along the Angolan

1671 margin in the late Quaternary." Nature Geoscience 9: 909-914.

1672

1673 Tessier, B., N. Delsinne and P. Sorrel (2013). "Holocene sedimentary infilling of a 1674 tide-dominated estuarine mouth. The example of the macrotidal Seine estuary 

(NW France)." Bulletin de la Societe Geologique de France 181(2): 87-98.

1676

1677 Texier, J.-P. and J. Meireles (1987). "As formaçoes Quaternarias do Litoral do Minho 1678

1679 (Portugal): propostas para uma nova abordagem climato-cronologica e dinâmica." Cadernos de Arqueologia Serie II(4): 9-33.

1680

1681 Thompson, W. G. and S. L. Goldstein (2005). "Open-system coral ages reveal 1682 persistent suborbital sea-level cycles." Science 308(5720): 401-404.

1684 Thompson, W. G., M. W. Spiegelman, S. L. Goldstein and R. C. Speed (2003). "An 1685 1686 open-system model for U-series age determinations of fossil corals." Earth and Planetary Science Letters 210(1-2): 365-381.

1687

1688 van de Plassche, O. (1986). Sea-level research : a manual for the collection and 1689 evaluation of data. Norwich, UK, Geo Books.

1690

1691 van Vliet-Lanoë, B., M. Laurent, J. L. Bahain, S. Balescu, C. Falguères, M. Field, B. 1692 Hallégouët and D. H. Keen (2000). "Middle Pleistocene raised beach 1693 anomalies in the English Channel: regional and global stratigraphic 
1696

1697

1698

1699

1700

1701

1702

1703

1704

1705

1706

1707

1708

1709

1710

1711

1712

van Vliet-Lanoë, B., N. Vandenberghe, M. Laurent, B. Laignel, A. Lauriat-Rage, S. Louwye, J.-L. Mansy, D. Mercier, B. Hallegouet, F. Meilliez, Y. Michel, G. Moguedet and J.-P. Vidier (2002). "Palaeogeographic evolution of northwestern Europe during the Upper Cenozoic." Geodiversitas 24(3): 511541.

Vérague, J. (1983). "Le gisement sablo-graveleux cénozoïque probable du hameau du Cloquant (La Glacerie, Normandie)." Norois 118: 293-302.

Waelbroeck, C., L. D. Labeyrie, E. Michel, J. C. Duplessy, J. F. McManus, K. Lambeck, E. Balbon and M. Labracherie (2002). "Sea-level and deep water temperature changes derived from benthic foraminefera isotopic records." Quaternary Science Reviews 21: 295-305.

Westaway, R. (1993). "Quaternary uplift of Southern Italy." Journal of Geophysical Research 98(B12): 21 741-21 772. 
1713 Westaway, R. (2009). "Quaternary uplift of northern England." Global and Planetary $1714 \quad$ Change 68: 357-382.

1715

1716 Whittow, J. B. (1960). "Some comments on the raised beach platform of South West 1717 Caernarvonshire and on an unrecorded raised beach at Porth Neigwl, North $1718 \quad$ Wales." Proceedings of the Geologist's Association 71: 31-39.

1719

1720 Wythe Cooke, C. (1930). "Correlation of coastal terraces." The Journal of Geology 1721 XXXVIII(7): 577-589.

1722

1723 Yamato, P., L. Husson, T. W. Becker and K. Pedoja (2013). "Passive margins getting 1724 squeezed in the mantle convection vice." Tectonics 32(6): 2013TC003375.

1725

1726 Yildirim, C., D. Melnick, P. Ballato, T. F. Schildgen, H. Echtler, A. E. Erginal, N. G. n. 1727 Käyak and M. R. Strecker (2013). "Differential uplift along the northern margin 1728 of the Central Anatolian Plateau: inferences from marine terraces." Quaternary 1729 Science Reviews 81(0): 12-28.

1730

1731 Zachos, J. C., G. R. Dickens and R. E. Zeebe (2008). "An early Cenozoic perspective 

283.

1734

1735 Zazo, C., P. G. Silva, J. L. Goy, C. Hillaire Marcel, B. Ghaleb, J. Lario, T. Bardaji and 1736 A. Gonzalez (1999). "Coastal uplift in continental collision plate boundaries: 1737 data from the last interglacial marine terrace of the Gibraltar Strait area (South 1738 Spain)." Tectonophysics 301: 95-109.

1739

1740 Ziegler, P. A. and P. Dèzes (2007). "Cenozoic uplift of Variscan Massifs in the Alpine 1741 foreland: Timing and controlling mechanisms." Global and Planetary Change 1742 58(1-4): 237-269.

1743 


\begin{tabular}{|c|c|c|c|c|c|c|c|c|c|c|c|c|c|}
\hline \multirow{3}{*}{ Area } & \multirow{3}{*}{ Site } & \multirow{3}{*}{ Terrace } & \multirow{3}{*}{$\begin{array}{l}\text { Chrono- } \\
\text { stratigraphy }\end{array}$} & \multirow{3}{*}{ Dating Method } & \multirow{3}{*}{ Reference } & \multicolumn{6}{|c|}{ Elevations } & & \\
\hline & & & & & & \multicolumn{2}{|c|}{\begin{tabular}{|c|}
$\begin{array}{c}\text { Elevation } \\
\text { of } \\
\text { deposits / } \\
\text { Landform }\end{array}$ \\
\end{tabular}} & \multicolumn{2}{|c|}{$\begin{array}{c}\text { Elevation } \\
\text { Strandine / } \\
\text { NGF }\end{array}$} & \multicolumn{2}{|c|}{$\begin{array}{l}\text { Elevation } \\
\text { Strandline / } \\
\text { landform }\end{array}$} & \multicolumn{2}{|c|}{ Age MIS } \\
\hline & & & & & & Ed & MoE & Es & MoE & Es & MoE & age & MoE \\
\hline $\begin{array}{l}\overrightarrow{\mathcal{U}} \\
\vec{\sigma} \\
\end{array}$ & $\begin{array}{c}\text { Anse du Brick, } \\
\text { Fermanville - Port Levy, } \\
\text { Anse de Quéry }\end{array}$ & T1 & MIS 5e & 5 OSL dating & $\begin{array}{l}\text { Coutard, 2003; } \\
\text { Coutard et al., } \\
2005 ; 2006\end{array}$ & $*$ & $*$ & 7 & 1 & 5 & 1 & 122 & 6 \\
\hline$\vec{\omega}$ & Herquemoulin & T1 & MIS 5e & Palynology & Clet, 1983 & 2 & 1 & 7 & 1 & 5 & 1 & 122 & 6 \\
\hline$\sum$ & Cap de la Hague & $\mathrm{T} 1$ & MIS 5e & morphostratigraphy & this study & * & * & 7 & 1 & 5 & 1 & 122 & 6 \\
\hline
\end{tabular}




\begin{tabular}{|c|c|c|c|c|c|c|c|c|c|}
\hline \multirow[t]{2}{*}{ Terrace } & \multirow[t]{2}{*}{$\begin{array}{c}\text { Chrono- } \\
\text { stratigraphy }\end{array}$} & \multicolumn{2}{|c|}{$\begin{array}{c}\text { Elevation } \\
\text { Strandine / } \\
\text { NGF }\end{array}$} & \multicolumn{2}{|c|}{$\begin{array}{l}\text { Elevation } \\
\text { Strandline / } \\
\text { landform }\end{array}$} & \multicolumn{2}{|c|}{ Age MIS } & \multicolumn{2}{|c|}{ Apparent uplif } \\
\hline & & Es & MoE & Es & MoE & age & MoE & $\mathbf{U} \max$ & $\mathrm{U} \min$ \\
\hline T1 & MIS 5e & 7 & 1 & 5 & 1 & 122 & 6 & 0.05 & 0.03 \\
\hline T2 & MIS 7 & 15 & 2 & 12 & 2 & 217.5 & 27.5 & 0.07 & 0.04 \\
\hline T3 & MIS 9 & 25 & 3 & 22 & 3 & 324.5 & 18.5 & 0.08 & 0.06 \\
\hline T4 & MIS 11 & 33 & 3 & 29 & 3 & 390 & 30 & 0.09 & 0.06 \\
\hline
\end{tabular}




\begin{tabular}{|c|c|c|c|c|c|c|c|c|}
\hline & & & \multicolumn{4}{|c|}{ Apparent MIS 5e uplift rates } & \multirow{4}{*}{\begin{tabular}{|c} 
Corre \\
U maximum \\
0.12 \\
$\begin{array}{c}\text { minimum } \\
\text { extrapolated } \\
\text { age }\end{array}$
\end{tabular}} \\
\hline & & \multirow{2}{*}{\multicolumn{2}{|c|}{ Elevation }} & \multirow{3}{*}{\begin{tabular}{|c|} 
U maximum \\
0.05 \\
$\begin{array}{c}\text { minimum } \\
\text { extrapolated } \\
\text { age }\end{array}$ \\
\end{tabular}} & \multirow{3}{*}{\begin{tabular}{|c|}
$U$ minimum \\
0.03 \\
$\begin{array}{c}\text { maximum } \\
\text { extrapolated } \\
\text { age }\end{array}$ \\
\end{tabular}} & \multirow{2}{*}{\multicolumn{2}{|c|}{$\begin{array}{c}\text { U mean } \\
0.04\end{array}$}} & \\
\hline & & & & & & & & \\
\hline & & E & Moe & & & $\begin{array}{c}\text { mean } \\
\text { extrapolated } \\
\text { age } \\
\end{array}$ & $\begin{array}{c}\text { mean } \\
\text { extrapolated } \\
\text { age error } \\
\end{array}$ & \\
\hline \multirow{2}{*}{ rasa 1} & distal & 54 & 5 & 980 & 1967 & 1473 & 493 & 408 \\
\hline & proximal & 86 & 5 & 1620 & 3033 & 2327 & 707 & 675 \\
\hline \multirow{2}{*}{ rasa 2} & distal & 95 & 5 & 1800 & 3333 & 2567 & 767 & 750 \\
\hline & proximal & 138 & 5 & 2660 & 4767 & 3713 & 1053 & 1108 \\
\hline \multirow{2}{*}{ rasa 3} & distal & 148 & 5 & 2860 & 5100 & 3980 & 1120 & 1192 \\
\hline & proximal & 165 & 5 & 3200 & 5667 & 4433 & 1233 & 1333 \\
\hline \multirow{2}{*}{ rasa 4} & distal & 172 & 5 & 3340 & 5900 & 4620 & 1280 & 1392 \\
\hline & proximal & 185 & 10 & 3500 & 6500 & 5000 & 1500 & 1458 \\
\hline
\end{tabular}




\begin{tabular}{|c|c|c|c|c|c|c|}
\hline MIS & $\begin{array}{c}\text { Uplift } \\
\text { rate } \\
(\mathrm{mm} / \mathrm{yr})\end{array}$ & $\begin{array}{c}\text { Highstan } \\
\mathrm{d}(\mathrm{ka})\end{array}$ & $\begin{array}{c}\text { sea level } \\
\text { corrected to } \\
\text { to }(\mathrm{m})\end{array}$ & $\begin{array}{c}\text { calculated } \\
\text { expected IE } \\
(\mathrm{m})\end{array}$ & $\begin{array}{c}\text { Measured IE } \\
(\mathrm{m})\end{array}$ & $\begin{array}{c}\text { Terrace } \\
\text { allocation }\end{array}$ \\
\hline $\mathbf{5 c}$ & $\mathbf{0 . 0 1}$ & $\mathbf{1 0 0}$ & $\mathbf{- 2 5}$ & $\mathbf{- 2 4}$ & $\mathbf{- 2 0}$ & offshore \\
\hline $\mathbf{5 e}$ & $\mathbf{0 . 0 1}$ & $\mathbf{1 2 5}$ & $\mathbf{5}$ & $\mathbf{6}$ & $\mathbf{5}$ & T1 \\
\hline $6 \mathrm{~d}$ & 0.01 & 175 & -30 & -28 & & \\
\hline $7 \mathrm{a}$ & 0.01 & 200 & -5 & -3 & & \\
\hline $7 \mathrm{c}$ & 0.01 & 217 & -30 & -28 & & \\
\hline $7 \mathrm{e}$ & 0.01 & 240 & -5 & -3 & & \\
\hline $9 \mathrm{a}$ & 0.01 & 285 & -30 & -27 & & \\
\hline $9 \mathrm{c}$ & 0.01 & 310 & -22 & -19 & & $\mathbf{T 2}$ \\
\hline $\mathbf{9 e}$ & $\mathbf{0 . 0 1}$ & $\mathbf{3 4 0}$ & $\mathbf{5}$ & $\mathbf{8}$ & $\mathbf{1 2}$ & \\
\hline $11 \mathrm{c}$ & 0.01 & 410 & -5 & -1 & & $\mathbf{T}$ \\
\hline $13 \mathrm{a}$ & 0.01 & 478 & 0 & 6 & & \\
\hline $\mathbf{1 3 c}$ & $\mathbf{0 . 0 1}$ & $\mathbf{5 2 5}$ & $\mathbf{2 0}$ & $\mathbf{2 5}$ & $\mathbf{2 2}$ & \\
\hline $15 \mathrm{a}(?)$ & 0.01 & 550 & 10 & 16 & & \\
\hline $15 \mathrm{a}(?)$ & 0.01 & 560 & 3 & 9 & & \\
\hline $15 \mathrm{c}$ & 0.01 & 590 & 20 & 26 & & \\
\hline $15 \mathrm{e}$ & 0.01 & 620 & 20 & 26 & & \\
\hline $17 \mathrm{c}$ & 0.01 & 695 & 10 & 17 & & \\
\hline$?$ & 0.01 & 740 & 5 & 12 & & \\
\hline $19 \mathrm{c} ?$ & 0.01 & 800 & 20 & 28 & & \\
\hline $21 \mathrm{a} ?$ & 0.01 & 855 & 20 & 29 & & \\
\hline $\boldsymbol{?}$ & $\mathbf{0 . 0 1}$ & $\mathbf{9 8 0}$ & $\mathbf{2 5}$ & $\mathbf{3 5}$ & $\mathbf{3 3}$ & \\
\hline & & & & & & \\
\hline
\end{tabular}




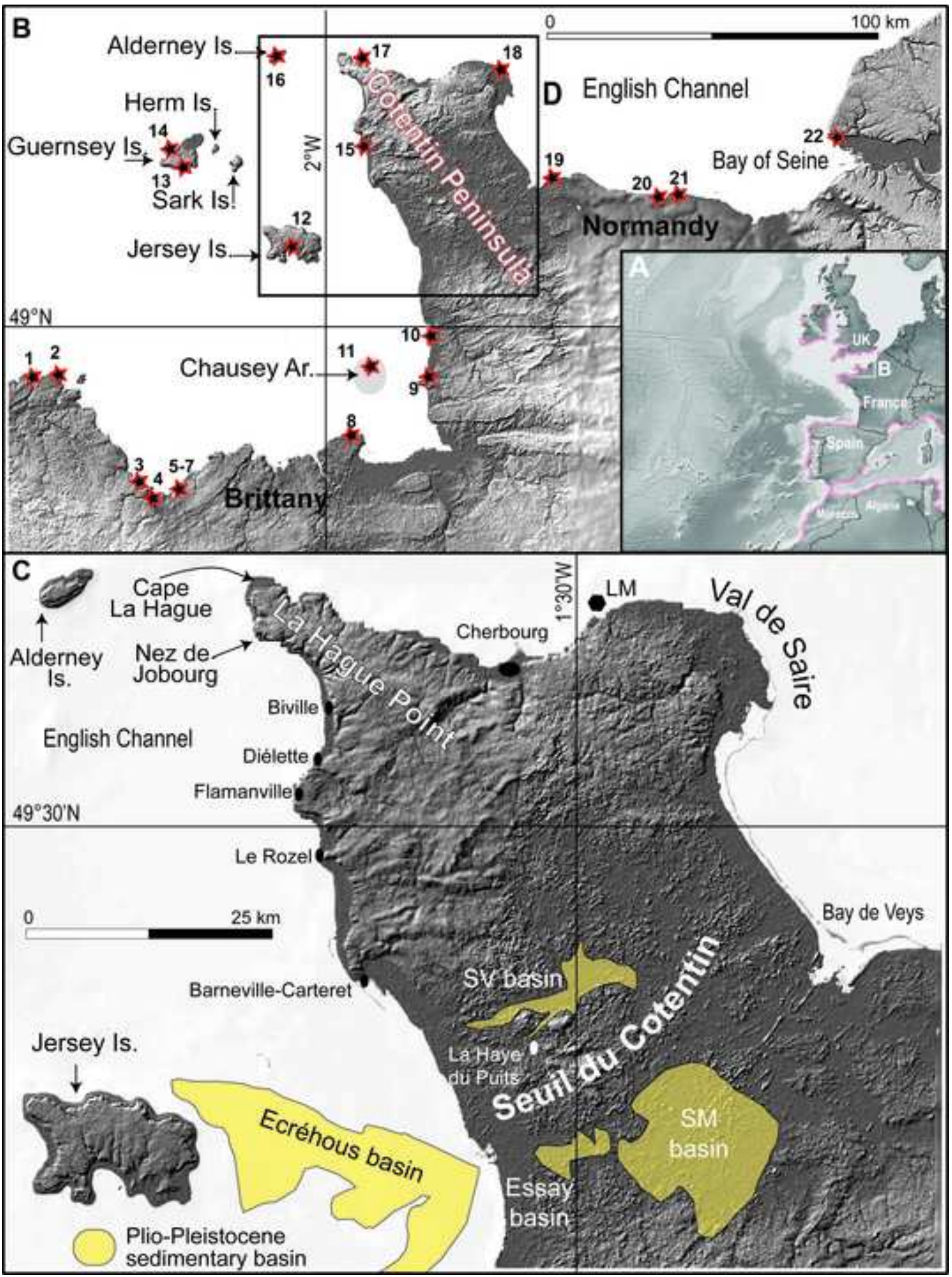




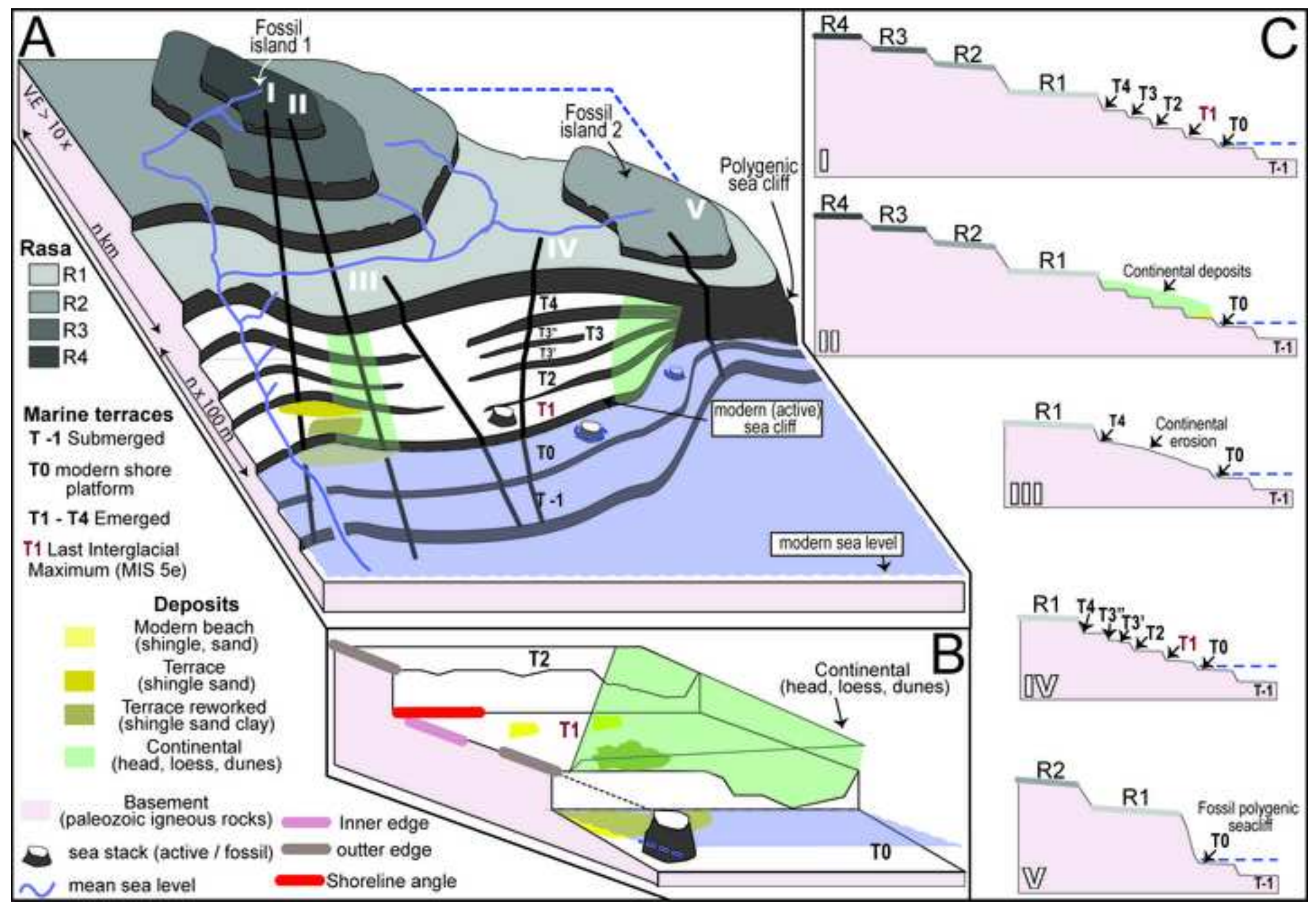




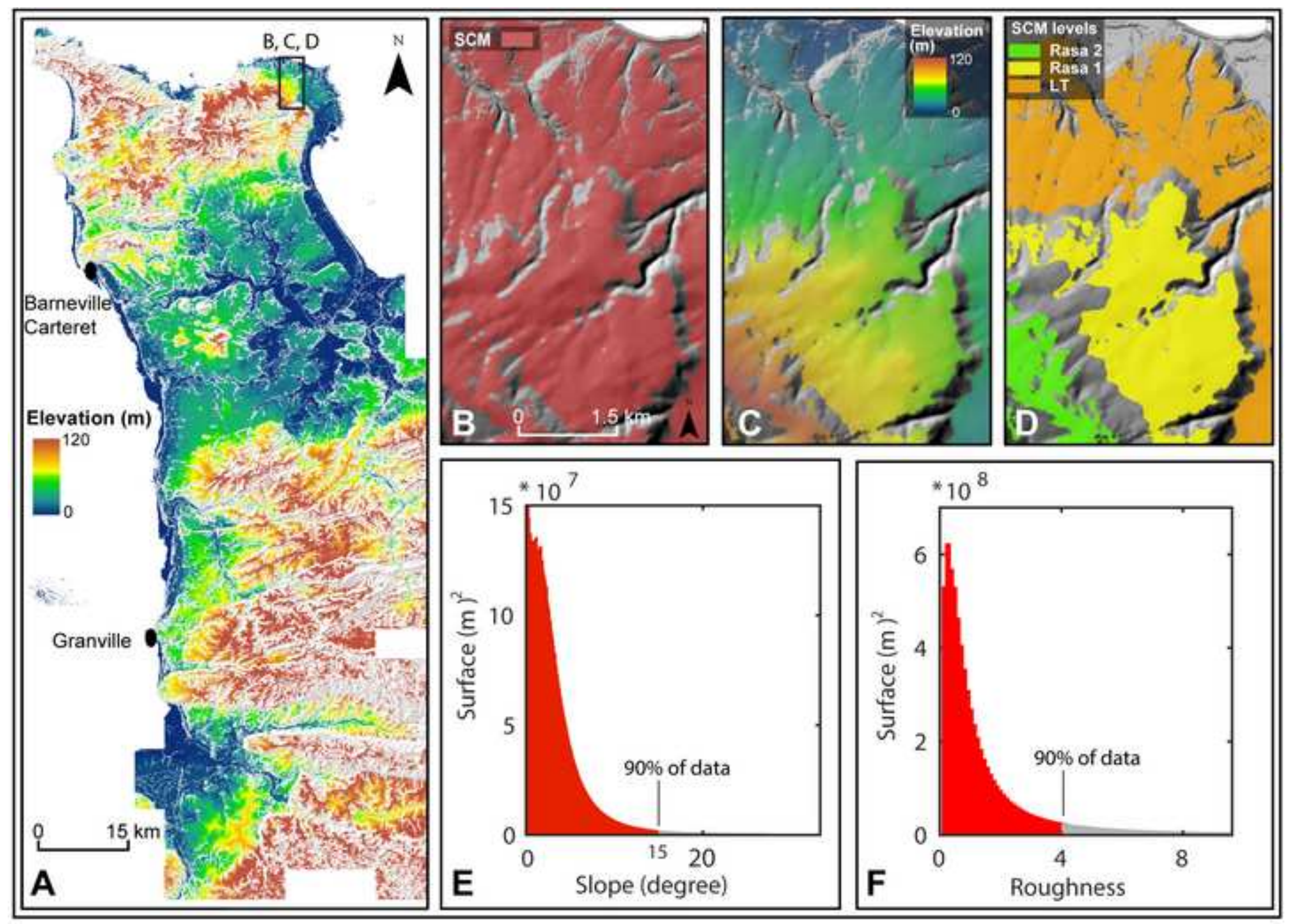




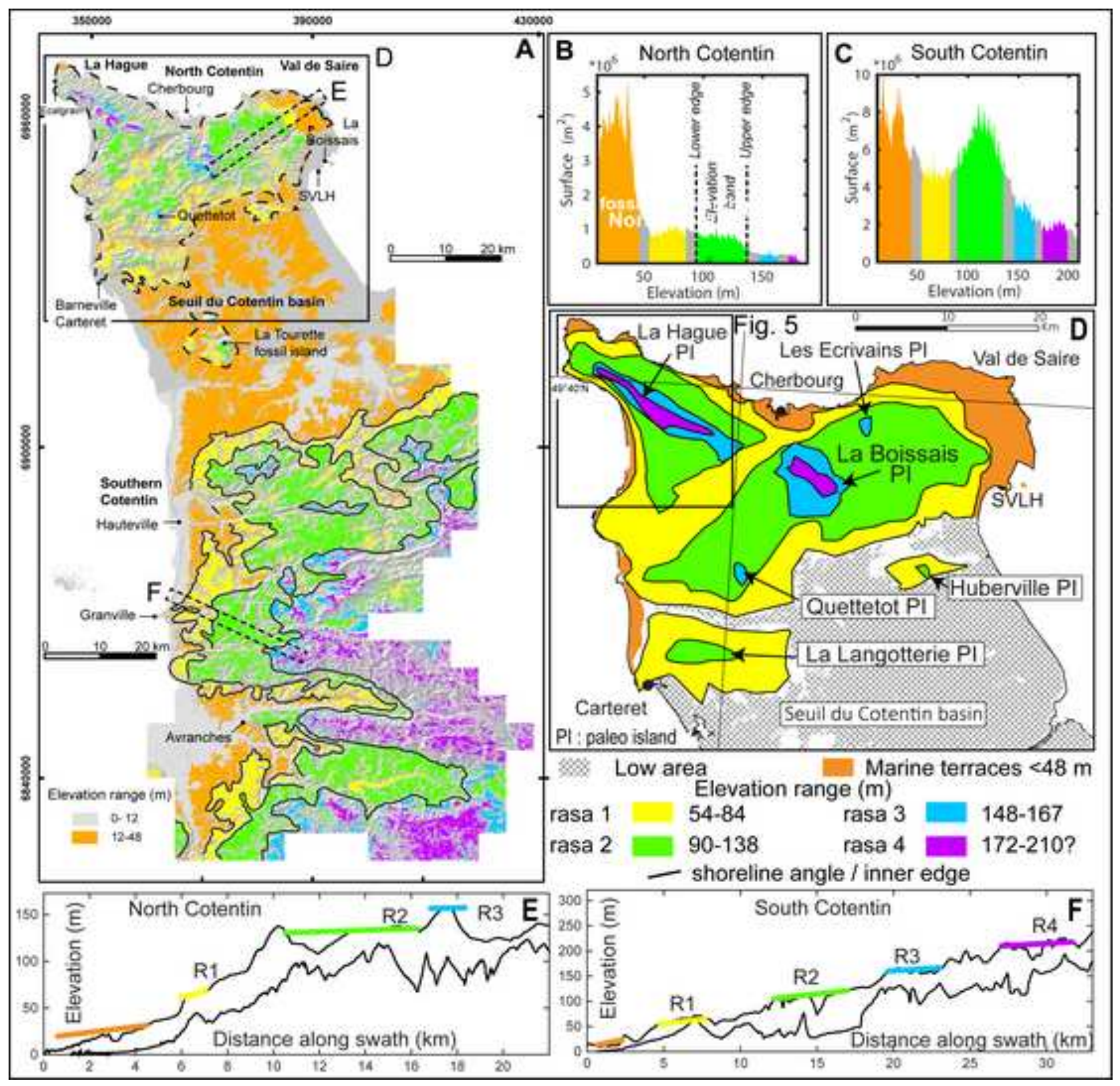




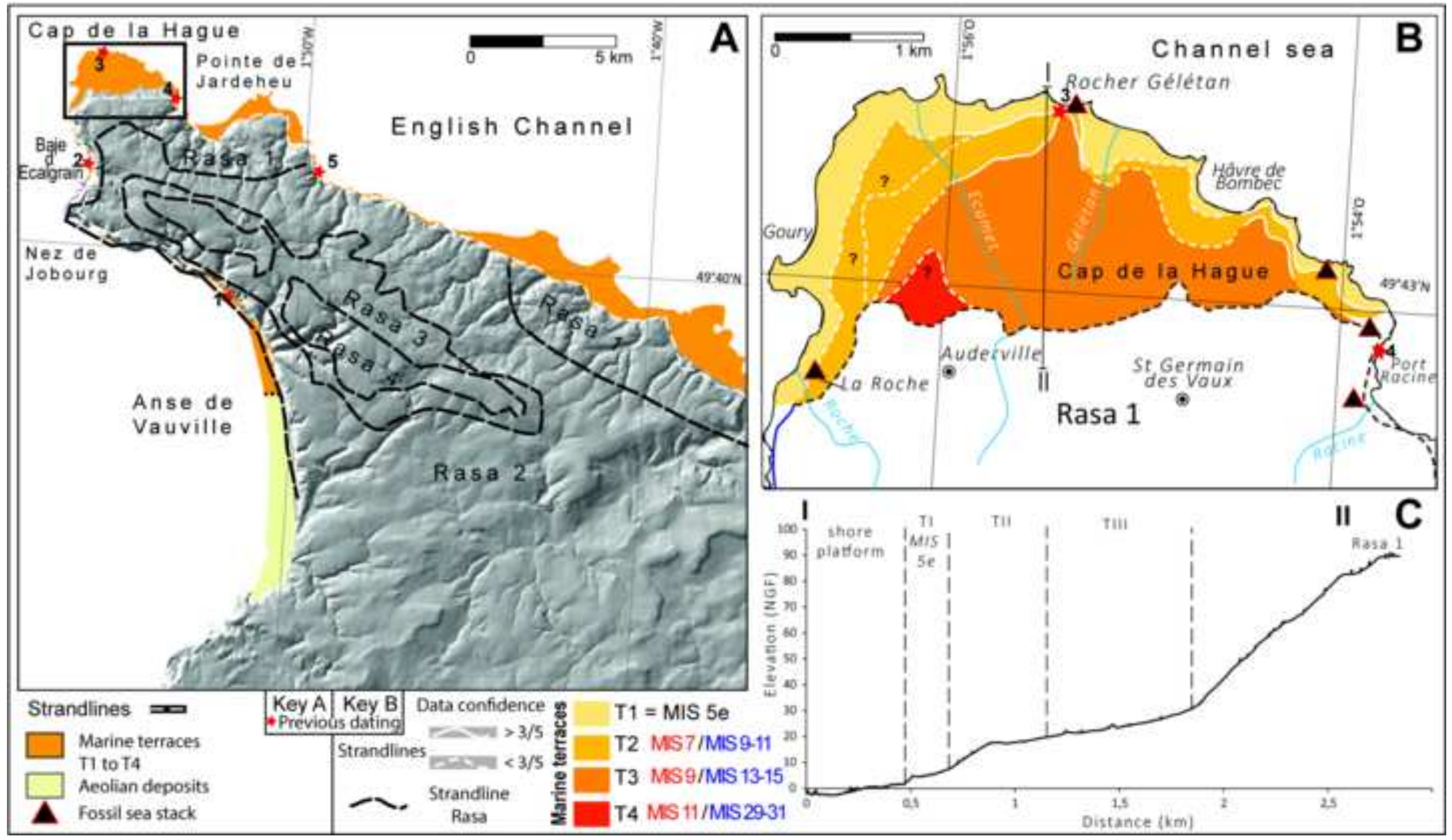


Figure 6 (Color)
Click here to download high resolution image

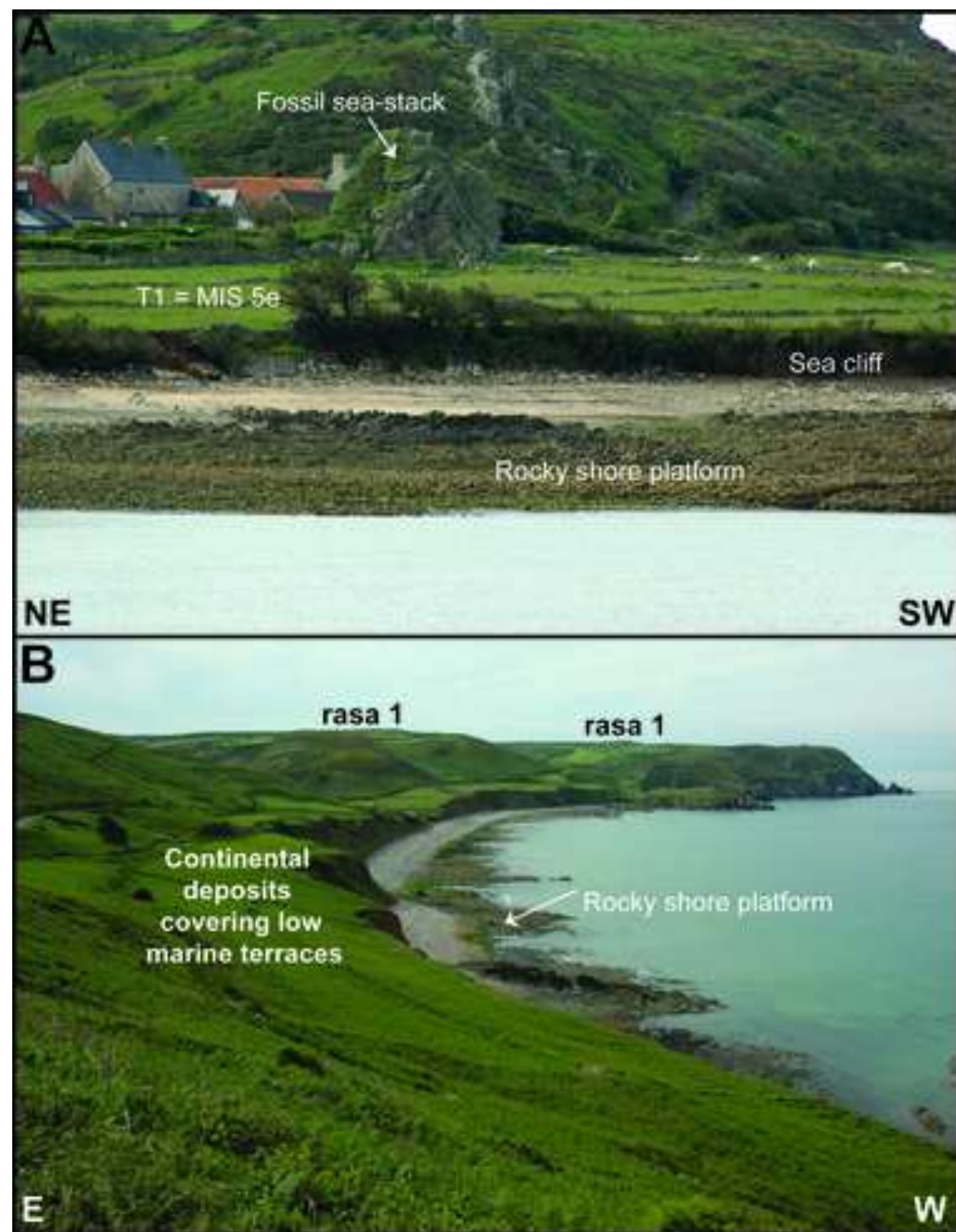

C

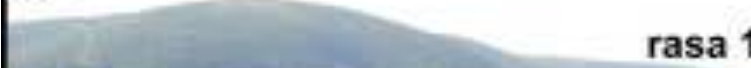

rasa 1

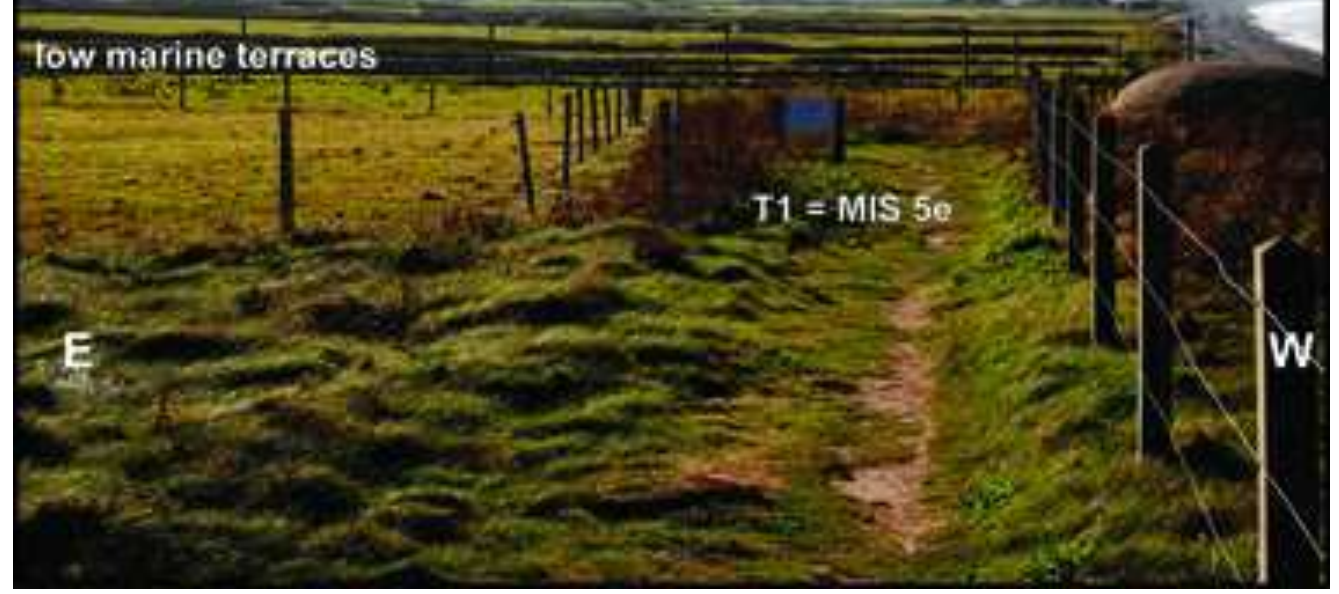




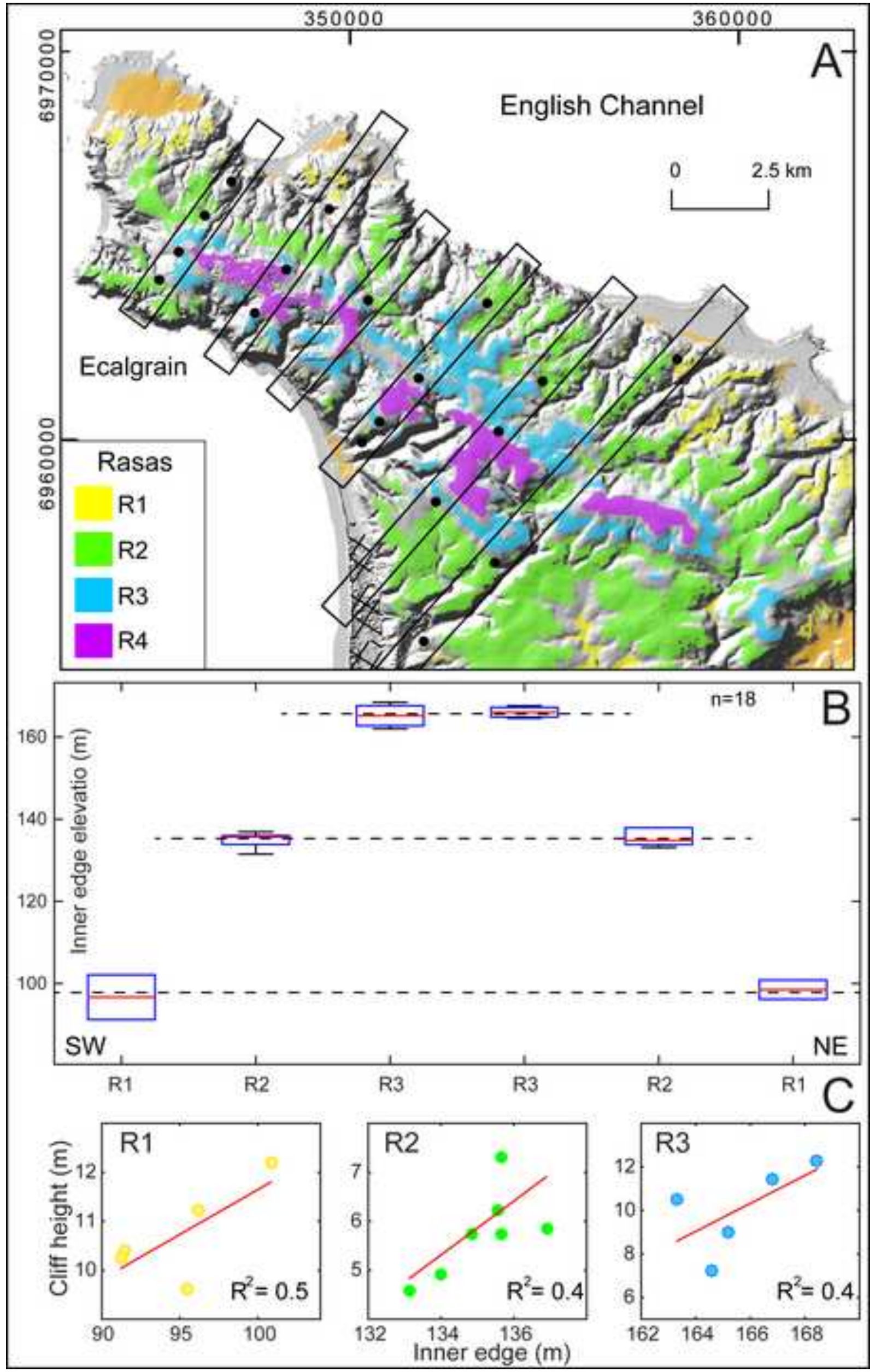




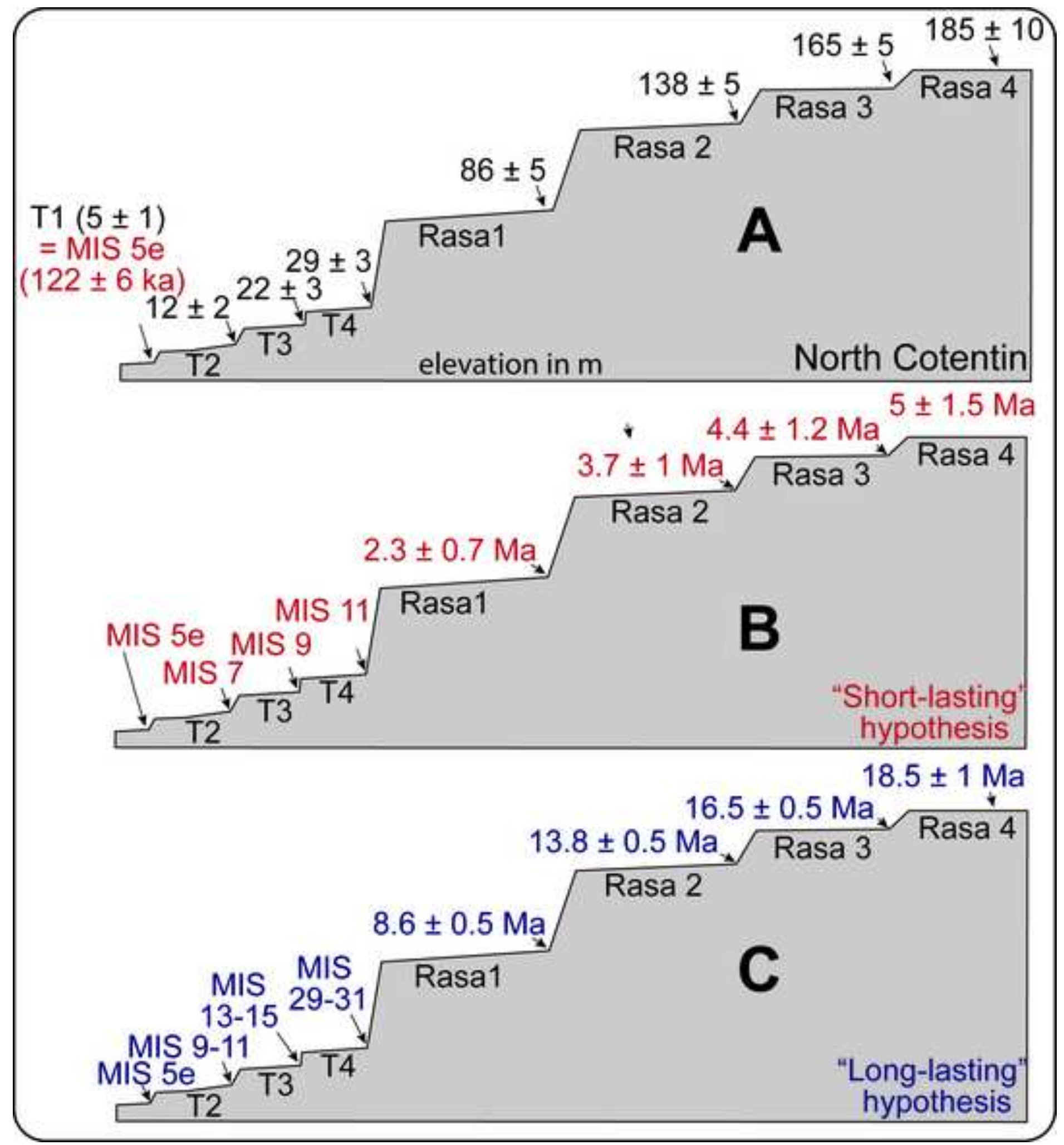


Figure 9 (Color)

Click here to download high resolution image

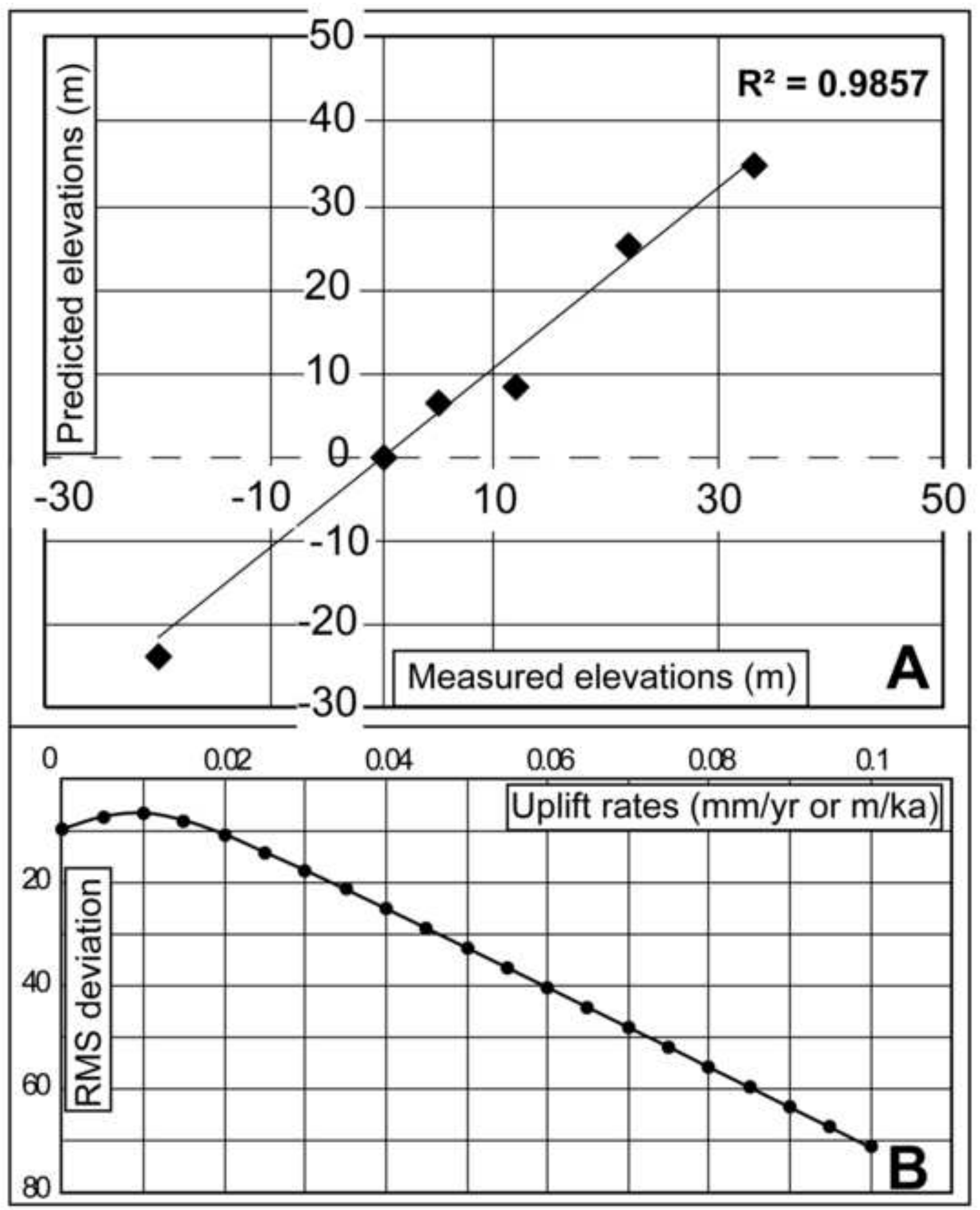


Figure (Color) 10
Click here to download high resolution image

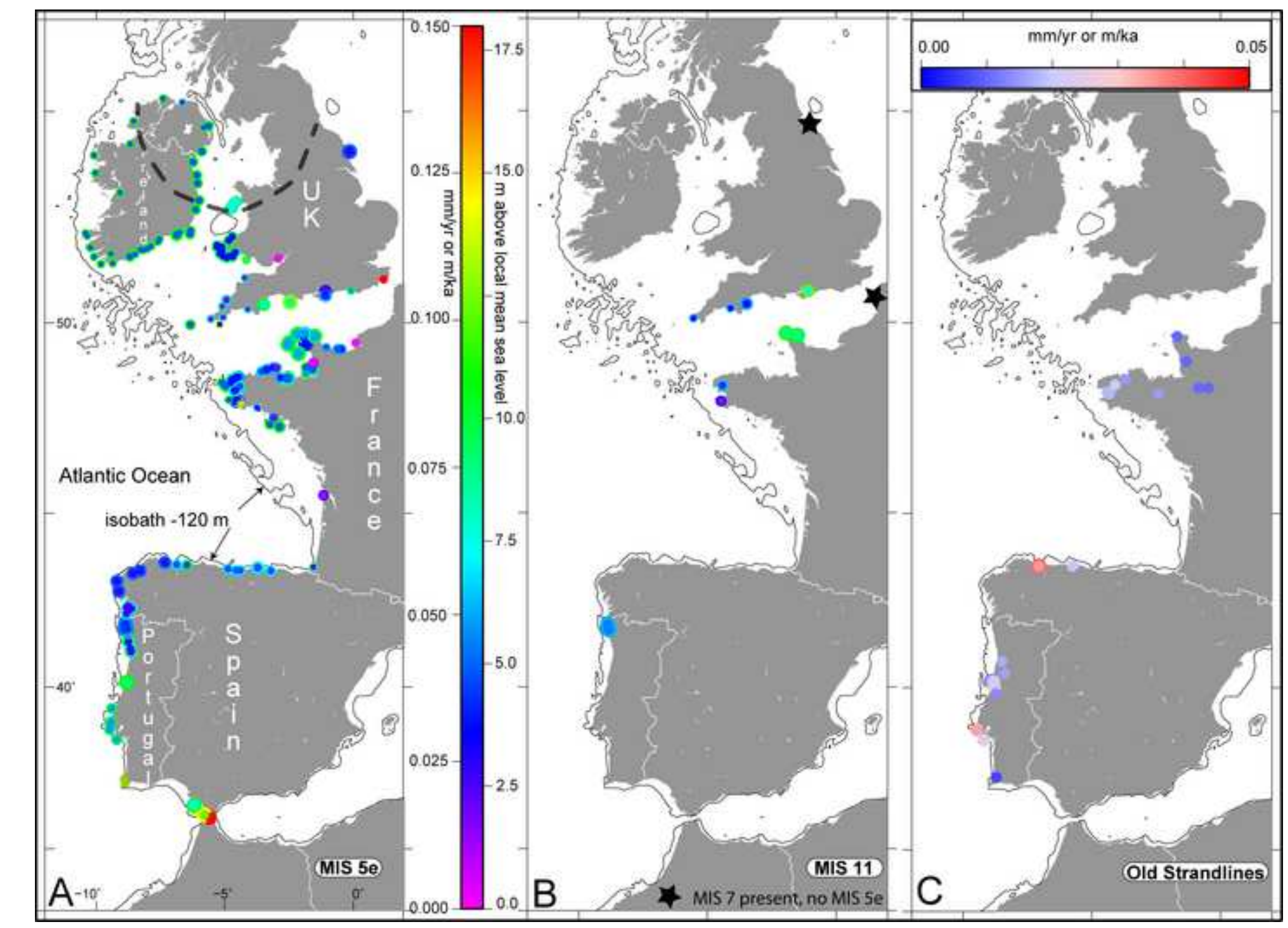


Figure 1 (Greyscale)
Click here to download high resolution image

Figure 1 (Greyscale)
Click here to download high resolution image

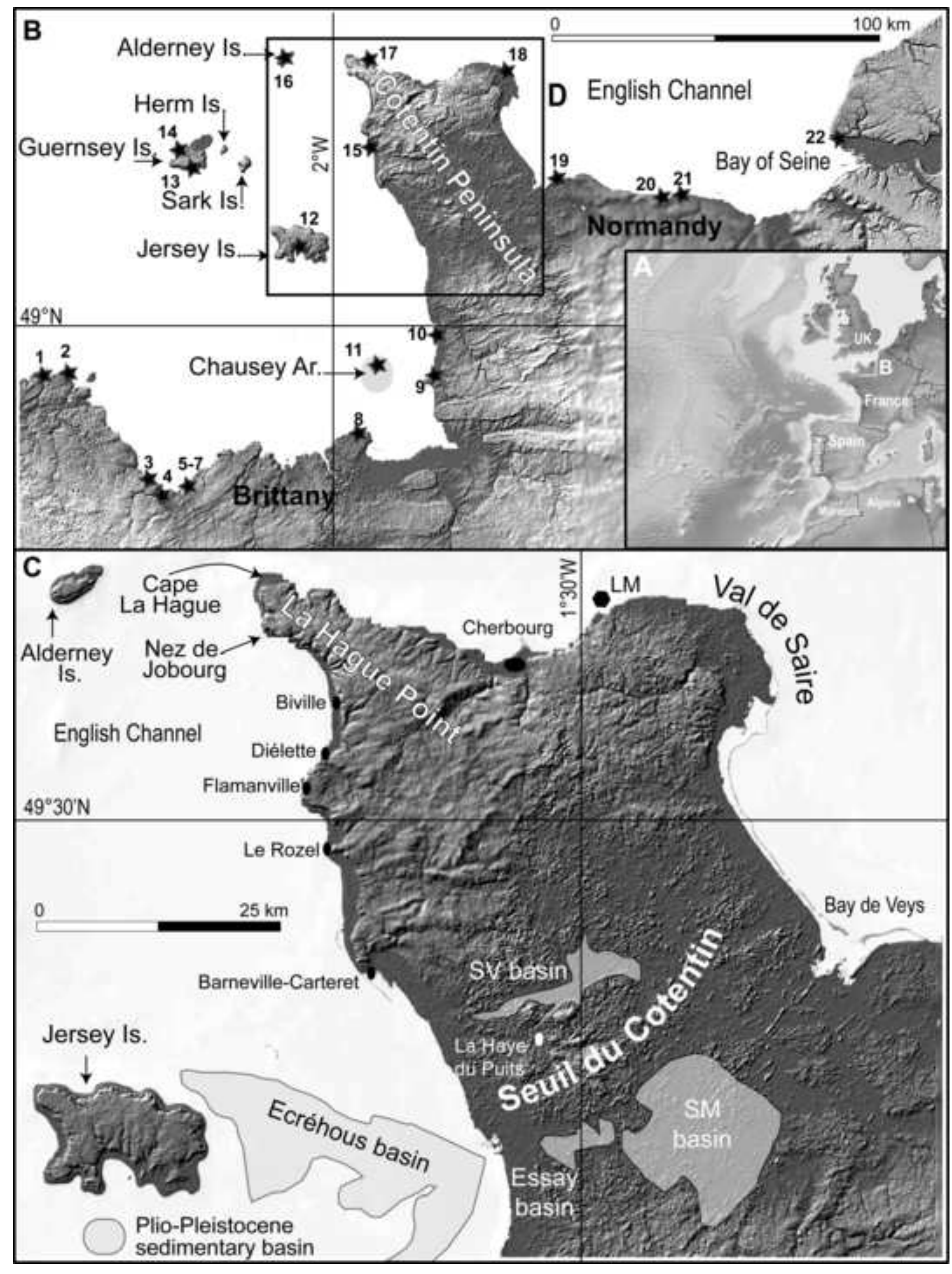




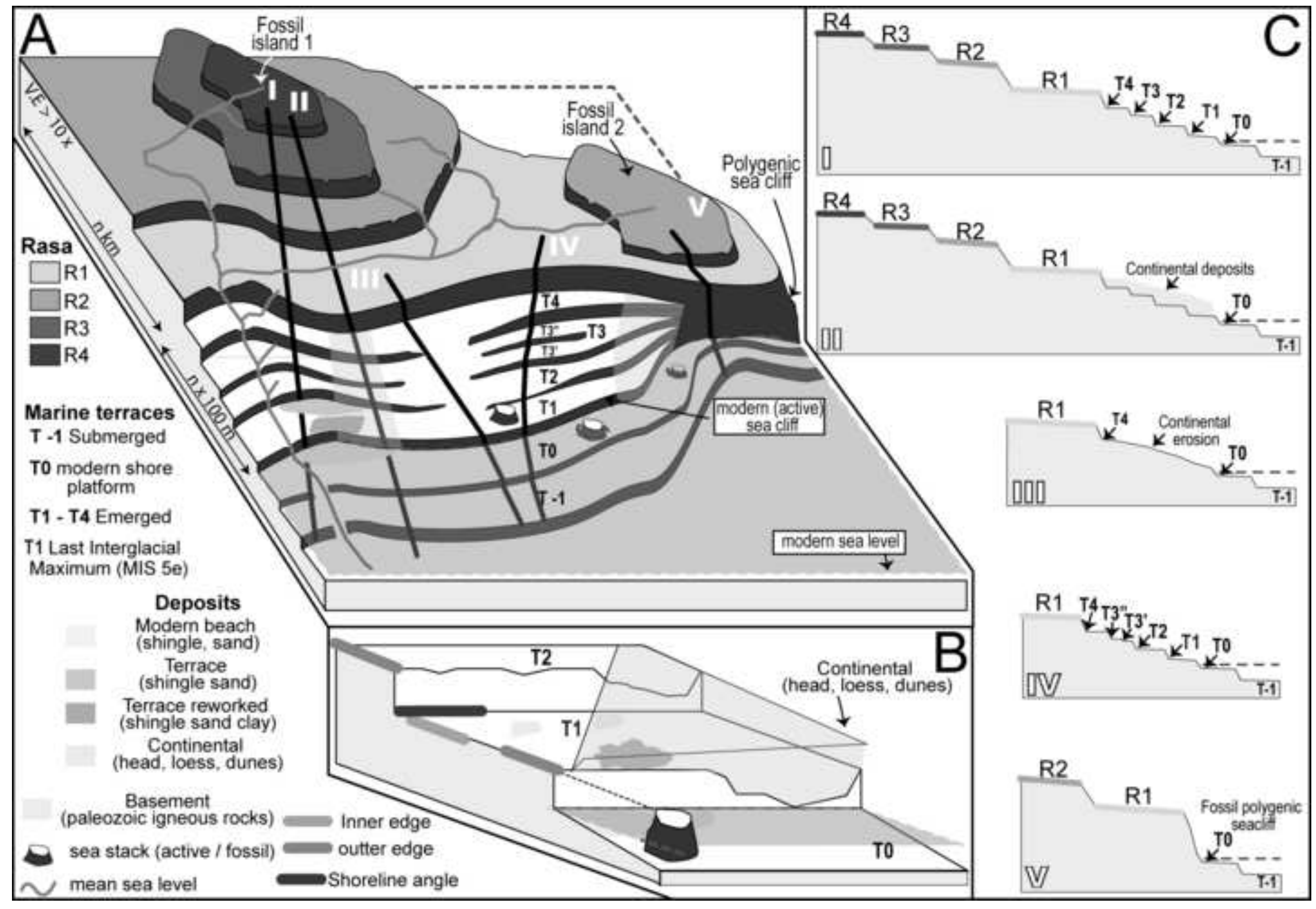




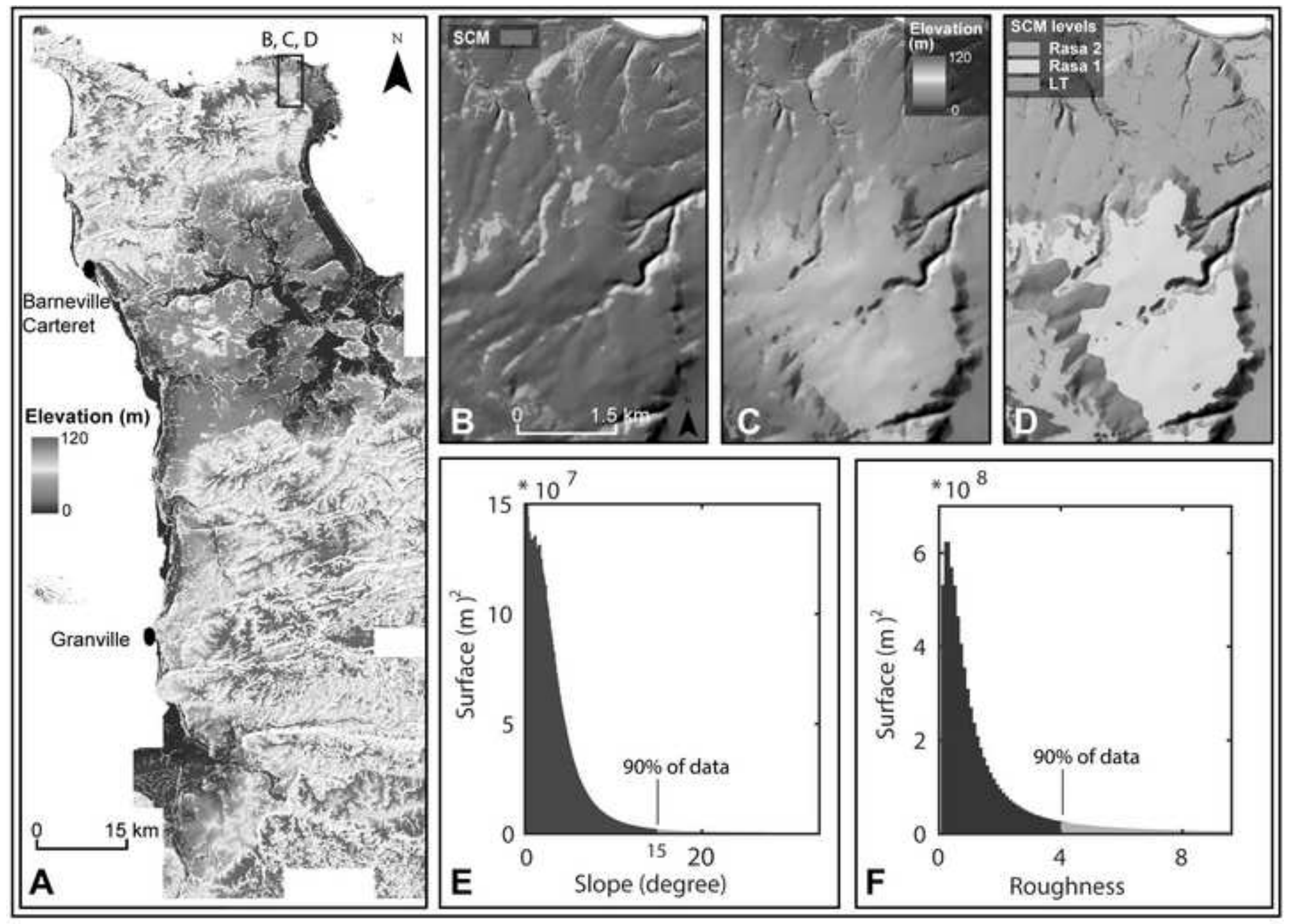




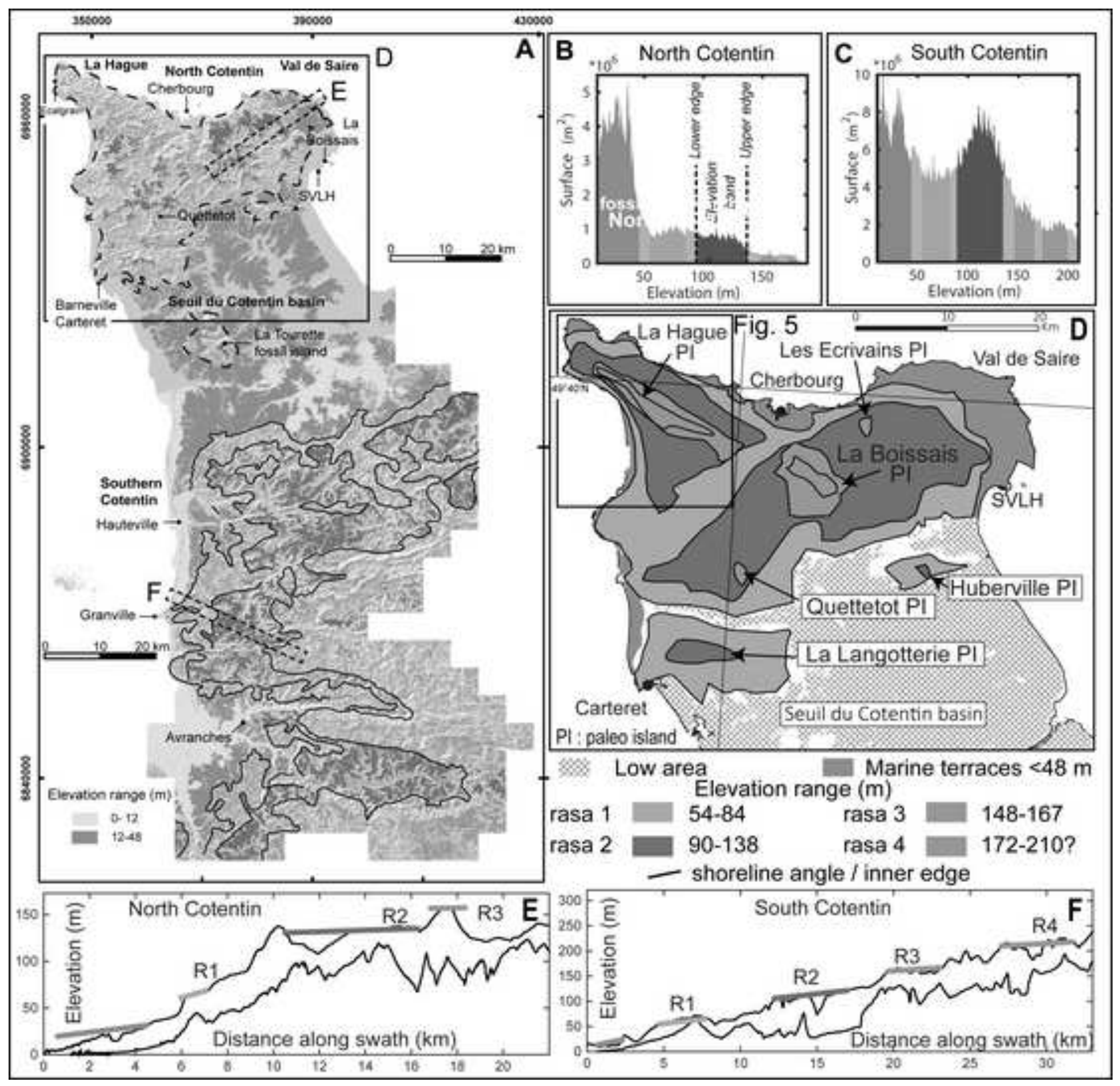




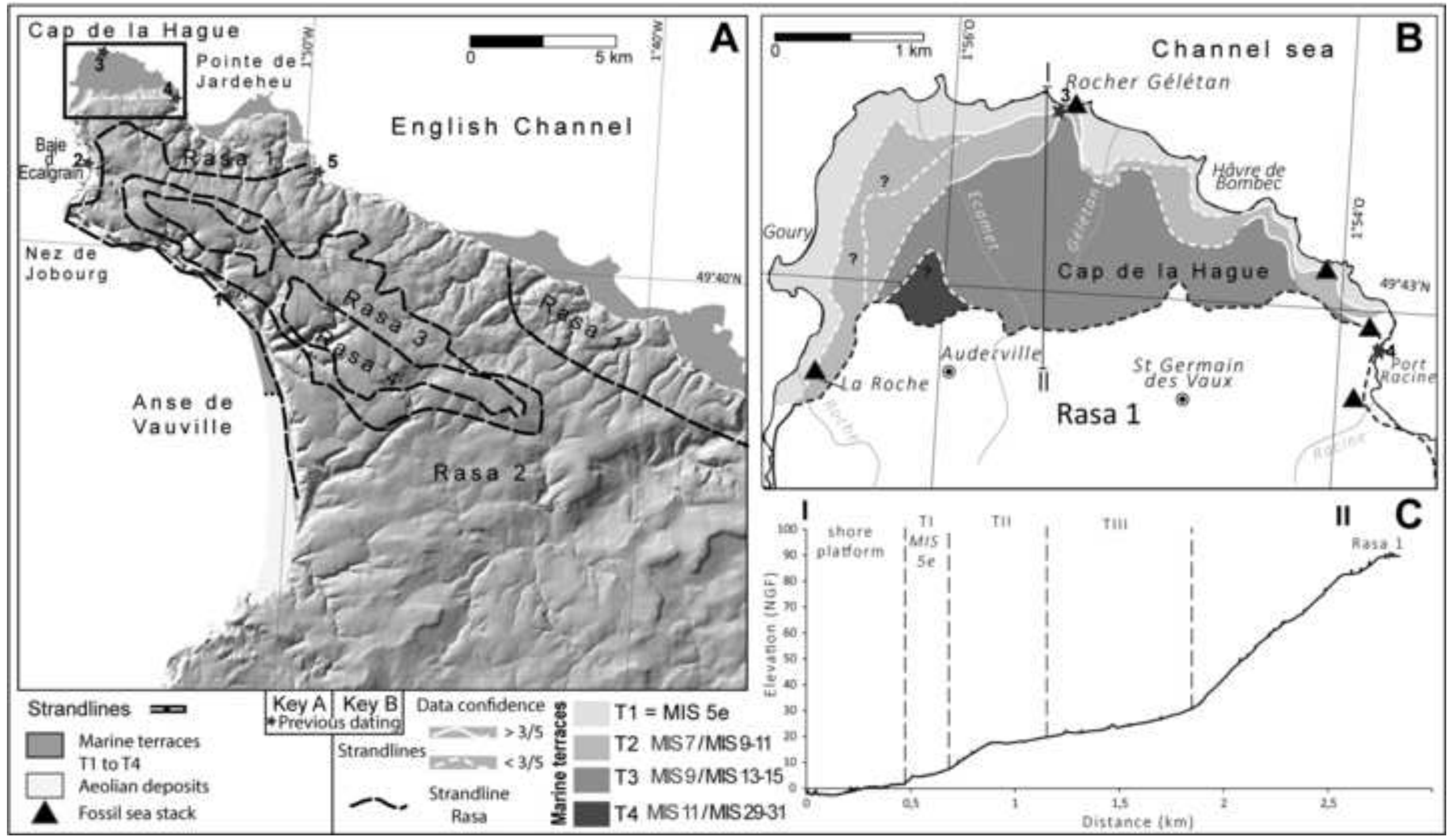


Click here to download high resolution image

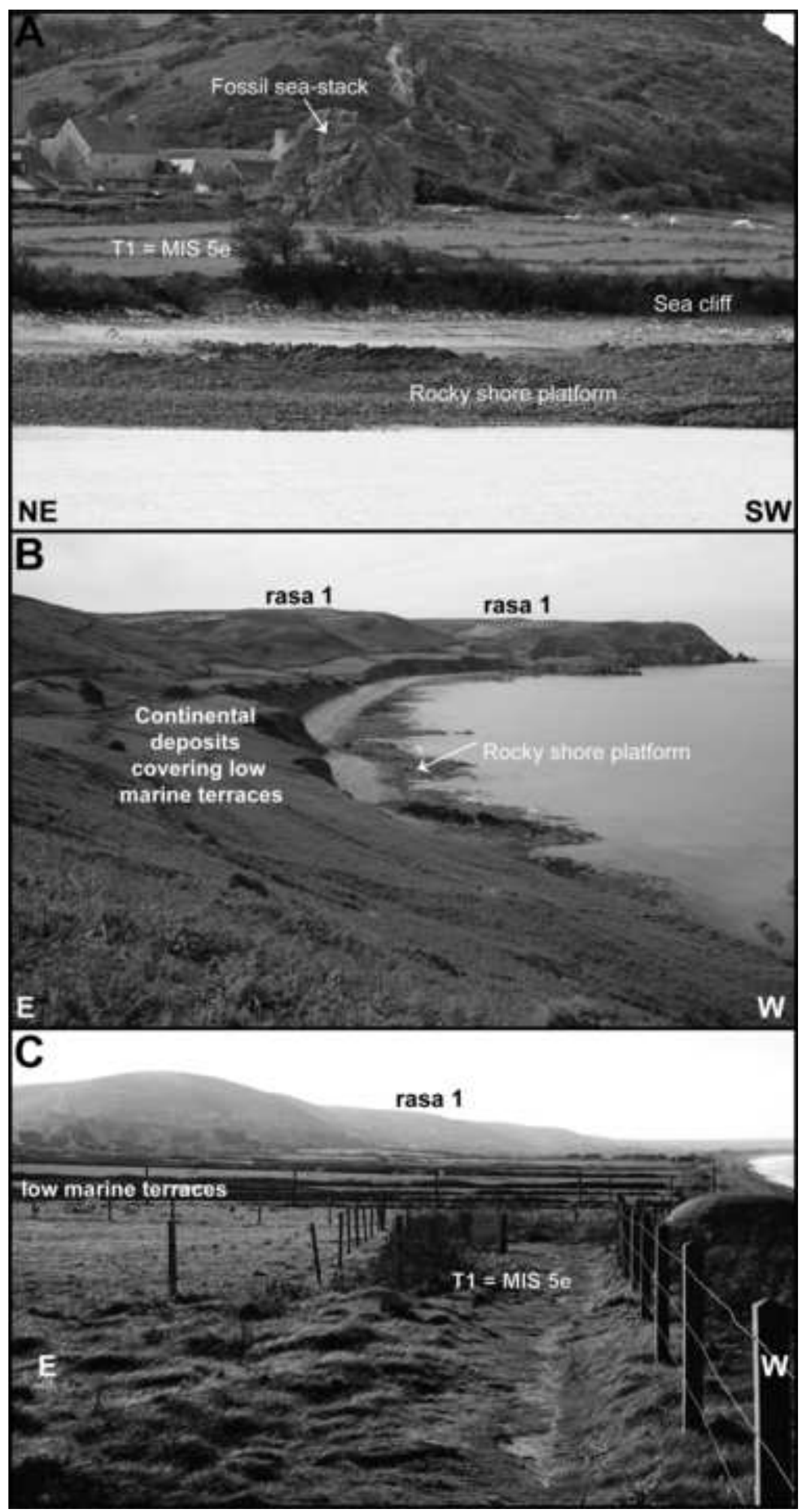




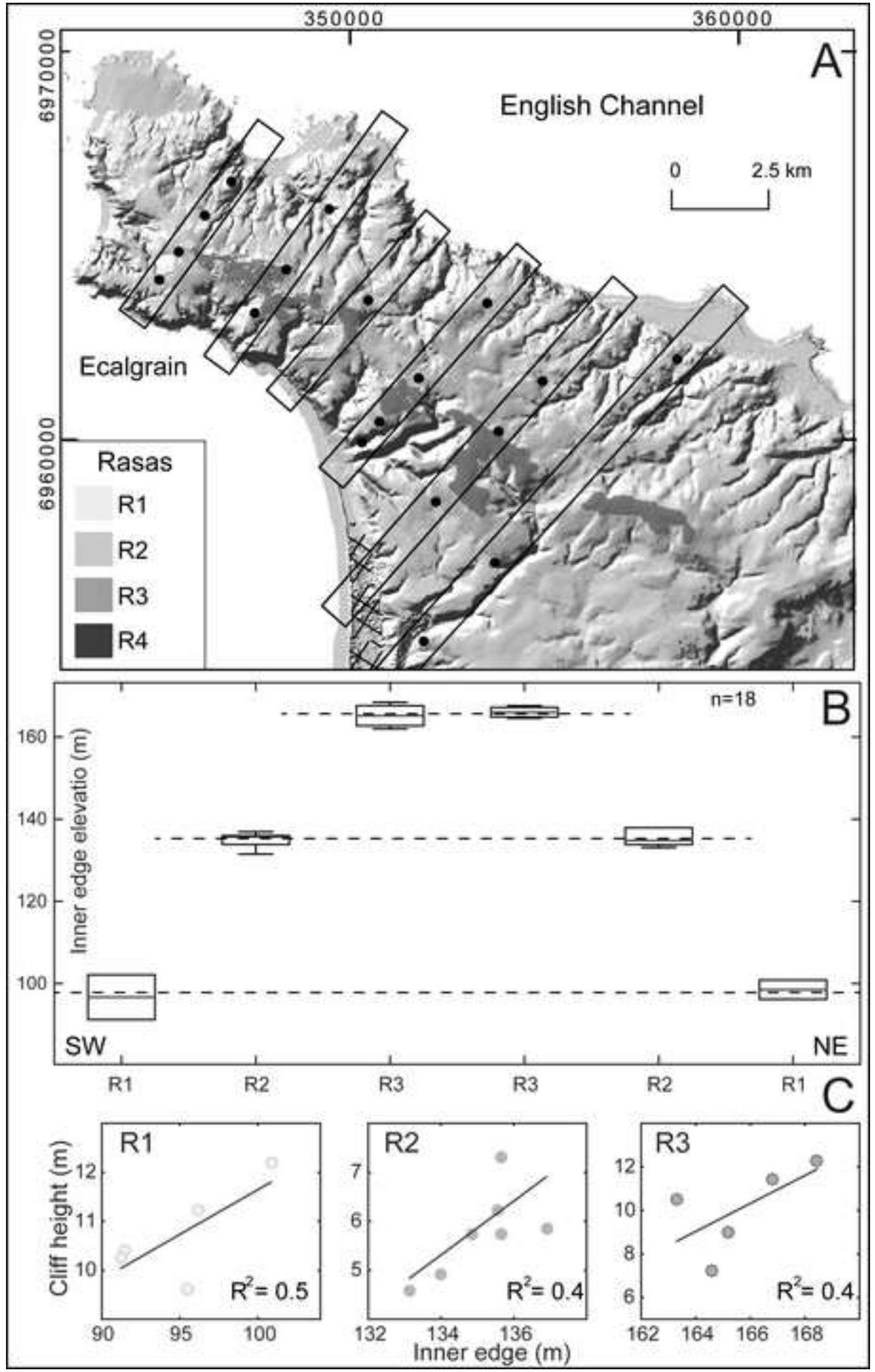




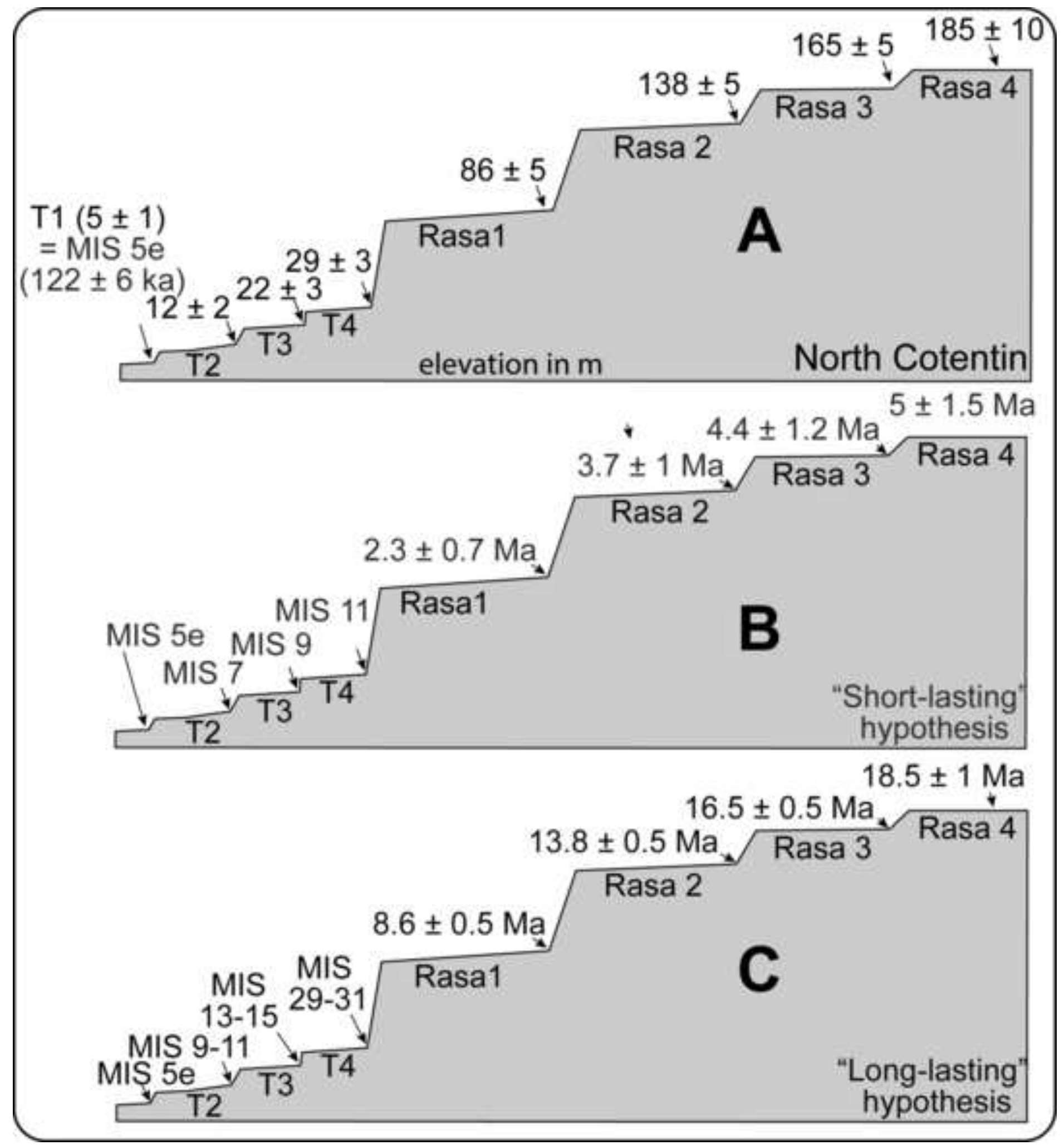




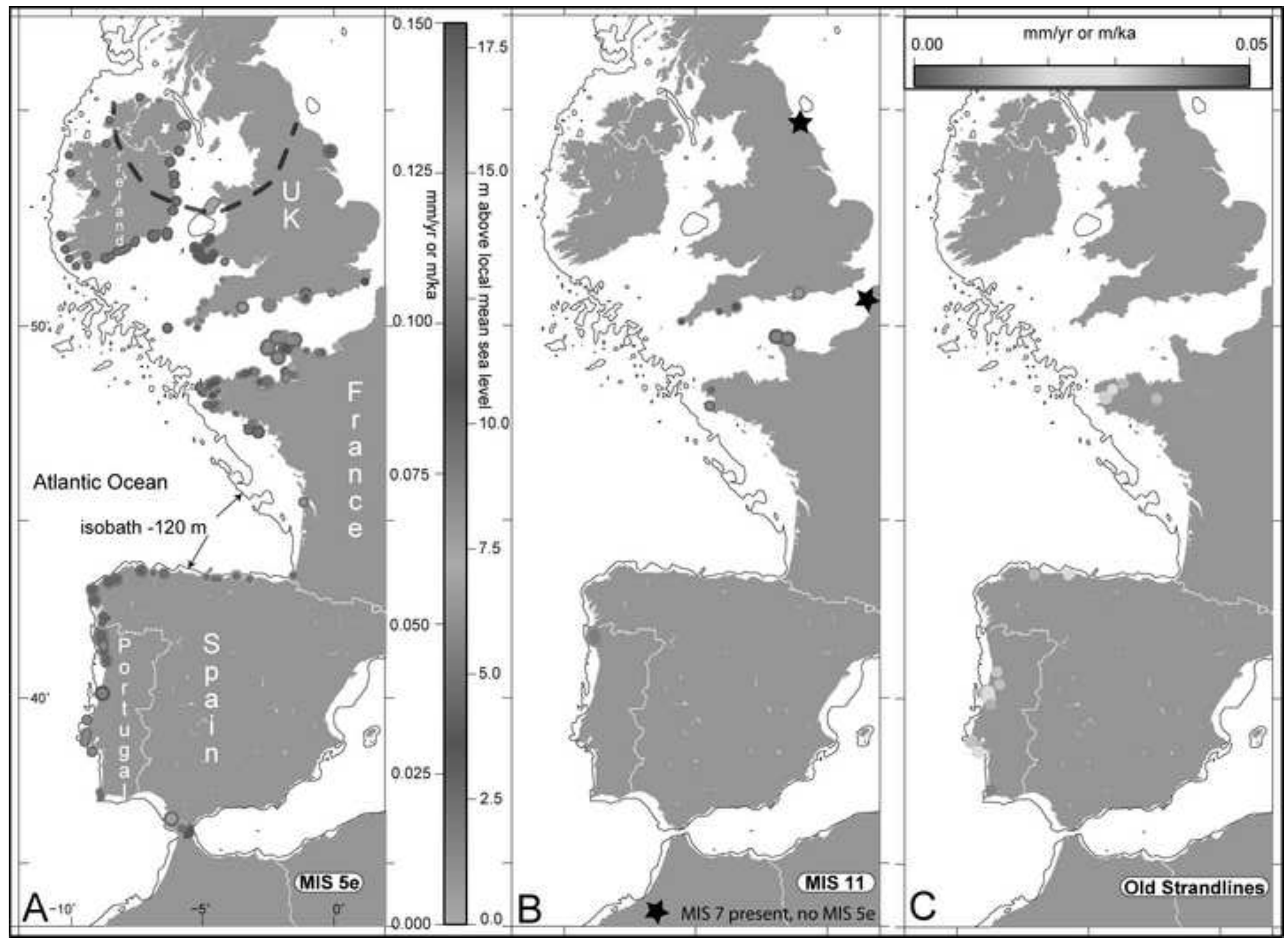



Edited supplementary material for online publication only
Click here to download Supplementary material for online

Click here to download Supplementary material for online publication only: GEOMOR-6655R1 Edited Intro supp data Geom Atla 

Supplementary material for online publication only Click here to download Supplementary material for online publication only: Supp Table 1 W Europe MIS 5e MIS 11revised.xls 

Supplementary material for online publication only
Click here to download Supplementary material for

Click here to download Supplementary material for online publication only: Supp Table 2 W Europe MIS 7.xls
publication only: Sup (1) (1) (1) (1)

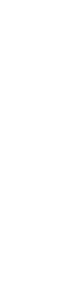
(1) . . . .

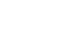

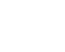
. . . . .

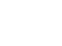

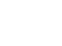

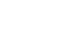
. . 

Supplementary material for online publication only
Click here to download Supplementary material for

Click here to download Supplementary material for online publication only: Supp Table 3 Old shoreline W Europe.xIsx 